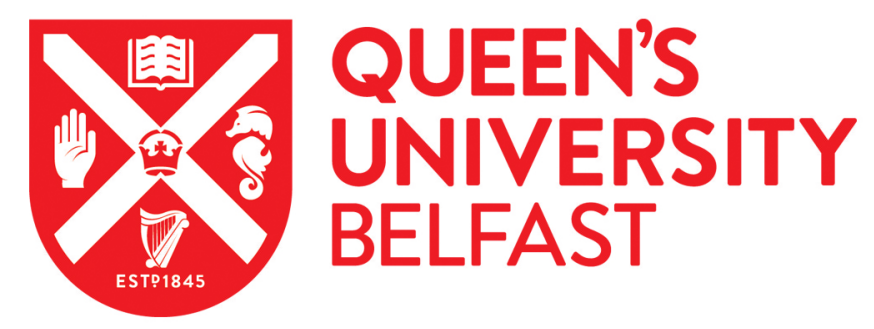

\title{
Effects of a century of mining and industrial production on metal contamination of a model saline ecosystem, Great Salt Lake, Utah
}

Wurtsbaugh, W., Leavitt, P., \& Moser, K. (2020). Effects of a century of mining and industrial production on metal contamination of a model saline ecosystem, Great Salt Lake, Utah. Environmental Pollution , 266(1), [115072]. https://doi.org/10.1016/j.envpol.2020.115072

Published in:

Environmental Pollution

Document Version:

Peer reviewed version

Queen's University Belfast - Research Portal:

Link to publication record in Queen's University Belfast Research Portal

Publisher rights

(C) 2020 Elsevier Ltd.

This manuscript is distributed under a Creative Commons Attribution-NonCommercial-NoDerivs License

(https://creativecommons.org/licenses/by-nc-nd/4.0/), which permits distribution and reproduction for non-commercial purposes, provided the author and source are cited.

\section{General rights}

Copyright for the publications made accessible via the Queen's University Belfast Research Portal is retained by the author(s) and / or other copyright owners and it is a condition of accessing these publications that users recognise and abide by the legal requirements associated with these rights.

Take down policy

The Research Portal is Queen's institutional repository that provides access to Queen's research output. Every effort has been made to ensure that content in the Research Portal does not infringe any person's rights, or applicable UK laws. If you discover content in the Research Portal that you believe breaches copyright or violates any law, please contact openaccess@qub.ac.uk. 


\title{
Manuscript Details
}

\section{Manuscript number}

Title
ENVPOL_2020_2873

Effects of a century of mining and industrial production on metal contamination of a model saline ecosystem, Great Salt Lake, Utah

\section{Article type}

Research Paper

\begin{abstract}
Abstract Effects of mining and metals production have been reported in freshwater lake sediments from around the world but are rarely quantified in saline lake sediments, despite the importance of these lake ecosystems. Here we used dated sediment cores from Great Salt Lake, Utah, USA, a large saline lake adjacent to one of the world's largest copper mines, to measure historical changes in the deposition of 22 metals. Metal concentrations were low prior to the onset of mining in the catchment in $1860 \mathrm{CE}$. Concentrations of copper, lead, zinc, cadmium, mercury and other metals began increasing in the late 1800s, with peaks in the 1950s, concomitant with enhanced mining and smelting activities. Sedimentary metal concentrations in the 1950s were 20-40-fold above background levels for copper, lead, silver and molybdenum. Concentrations of most metals in surficial sediments have decreased 2-5-fold, reflecting: 1) storage and mineralization of sedimenting materials in a deep brine layer, reducing metal transport to the sediments; 2) improved pollution control technologies, and; 3 ) reduction in mining activity beginning in the 1970s and 1980s. Despite reductions, concentrations of many metals in surficial sediments remain above acceptable contamination thresholds for aquatic ecosystems with migratory birds, and consumption advisories for mercury have been placed on three waterfowl species. The research also highlights that metal deposition in saline lakes is complicated by effects of hypersaline brines and deep-water anoxia in regulating sediment redox and release of metals to surface waters. Given the importance of saline lakes to migratory birds, metals contamination from mining and metals production should be a focus of saline lake remediation.
\end{abstract}

\section{Keywords}

Corresponding Author

Corresponding Author's Institution

Order of Authors

Suggested reviewers paleolimnology; pollution; selenium; mercury; monimolimnion

Wayne Wurtsbaugh

Utah State University

Wayne Wurtsbaugh, Peter Leavitt, Katrina Moser

Jules Blais, Daniel Engstrom, David Naftz, Neil Rose, Heather Jamieson, William Johnson

\section{Submission Files Included in this PDF}

\section{File Name [File Type]}

Cover Letter_Wurtsbaugh_Environ Pollution_Revised2.doc.pdf [Cover Letter]

Highlights.pdf [Highlights]

Graphical Abstract.tif [Graphical Abstract]

Metal paleolim_GSL_Env Poll_13 Apr 2020.pdf [Manuscript File]

declaration-of-competing-interests.docx [Conflict of Interest]

Metal_paleolimnology_GSL_Final 29 June 2014_PRINT.pdf [Supplementary Material]

\section{Submission Files Not Included in this PDF}

\section{File Name [File Type]}

Table S1_Site Locations-characteristics.xlsx [Supplementary Material]

Table S2a_Site 3 metal appendice.xlsx [Supplementary Material]

Table S2b_Site 4 metals appendice.xlsx [Supplementary Material] 
To view all the submission files, including those not included in the PDF, click on the manuscript title on your EVISE Homepage, then click 'Download zip file'.

\section{Research Data Related to this Submission}

There are no linked research data sets for this submission. The following reason is given:

Data is in the Supplementary Data files 


\section{Utah State \\ University}

WATERSHED SCIENCES DEPARTMENT

5210 OLD MAIN HILL

LOGAN UT 84322-5210

TELEPHONE: (435) 760-7625

FAX: (435) 797-1871

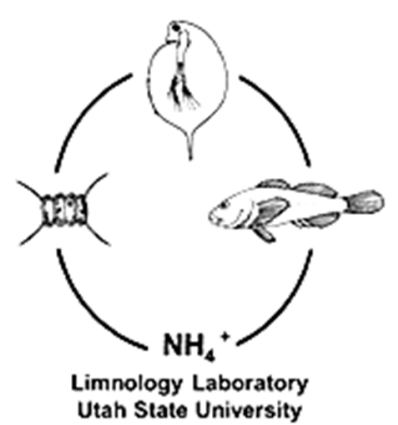

wayne.wurtsbaugh@usu.edu

19 April 2020

Drs. Christian Sonne and Eddy Zeng

Co-Editors in Chief

Environmental Pollution

Attn: Dr. Jörg Rinklebe

Dear Editors,

Please consider our re-submission of, Effects of a century of mining and industrial production on metal contamination of a model saline ecosystem, Great Salt Lake, Utah, for a Full Research Paper in

Environmental Pollution. All the materials have been uploaded to your website. The manuscript is based on a report submitted to the Utah Division of Water Quality. Our earlier manuscript was rejected because it had considerable overlap with that report, which had been posted in Digital Commons, a web depository for reports and other materials. We have corresponded with Dr. Rinklebe about the problem and in an email today he gave us permission to resubmit. I have requested that the report be removed from Digital Commons, but that might not occur until 20-21 April. I have also included the report in your submission website as 'Supporting data', but it should not be included in the final paper, if accepted.

Our manuscript compares documented rates of metal mining, atmospheric pollution, and environmental regulation with records of metal accumulation in the sediments of Great Salt Lake (GSL), the largest inland waterbody in the western USA. Unlike most previous metal-pollution studies, this lake serves as a model ecosystem for other saline ecosystems that account for nearly half of global inland waters by area. Such saline lakes exhibit properties of density stratification, elevated solute concentration, and variable oxygen content that complicate management of metal pollution and, in particular, the application of predictive models derived from freshwaters. These new records reveal for the first time, the source of metals to migratory waterfowl which use saline lakes as critical staging areas in western North America and elsewhere.

We feel the paper is novel in several respects. First, we demonstrate that while the onset of pollution mirrors that of mining development, the rate and extent of recovery from contamination is highly metalspecific, with several toxic compounds remaining above health advisories even 50 years after the onset of effective pollution regulation. Second, we demonstrate that the presence of deep-water, hypersaline, anoxic environments complicates prediction of recovery rates from metal pollution, leading to continued contamination of saltwater food webs in this iconic model ecosystem (e.g., As, Se, Hg).

Dr. Jörg Rinklebe has reviewed the previous submission, so he is the obvious co-editor to continue.

Co-authors Katrina A. Moser (kmoser@uwo.ca) and Peter R. Leavitt (Peter.Leavitt@uregina.ca) have approved this submission. 
Responses to the queries about our first submission are as follows:

1. Please use an asterisk to mark the corresponding author in the authors list. This was done on the title page of the manuscript, but I could not open the box on the submission page to change the first author (corresponding author).

2. The highlight points (3-5 bullets) should be rewritten in complete sentences to convey the main findings of the study (rather than backgrounds or what you have done), with no more than 85 characters per bullet point (including spaces). These have been rewritten to focus on the findings.

3. All journal names should be abbreviated in the references. The names are now all abbreviated. For some reason my EndNote template for your journal had only abbreviated a portion of the journal names in the previous version of the manuscript.

4. Please remove the individually uploaded figure files. Duplicate figures may confuse the handling editor. These have been removed.

I apologize for not including these responses in the cover letter. I had put them in the Comments box in the submission website, but not here.

Sincerely,

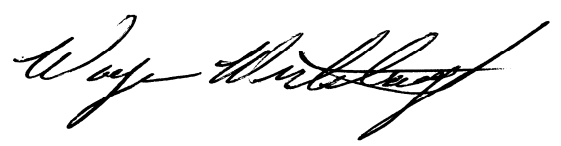

Wayne Wurtsbaugh, Corresponding author Professor Emeritus 


\section{Highlights}

- Sediments in Great Salt Lake were contaminated by mining beginning in the late 1800s.

- Metals in the sediments have declined since 1950 due to salt-density stratification.

- Additional recovery occurred after implementation of the 1963 U.S. Clean Air Act.

- Most metals, however, remain high and threaten the lake's abundant bird population. 


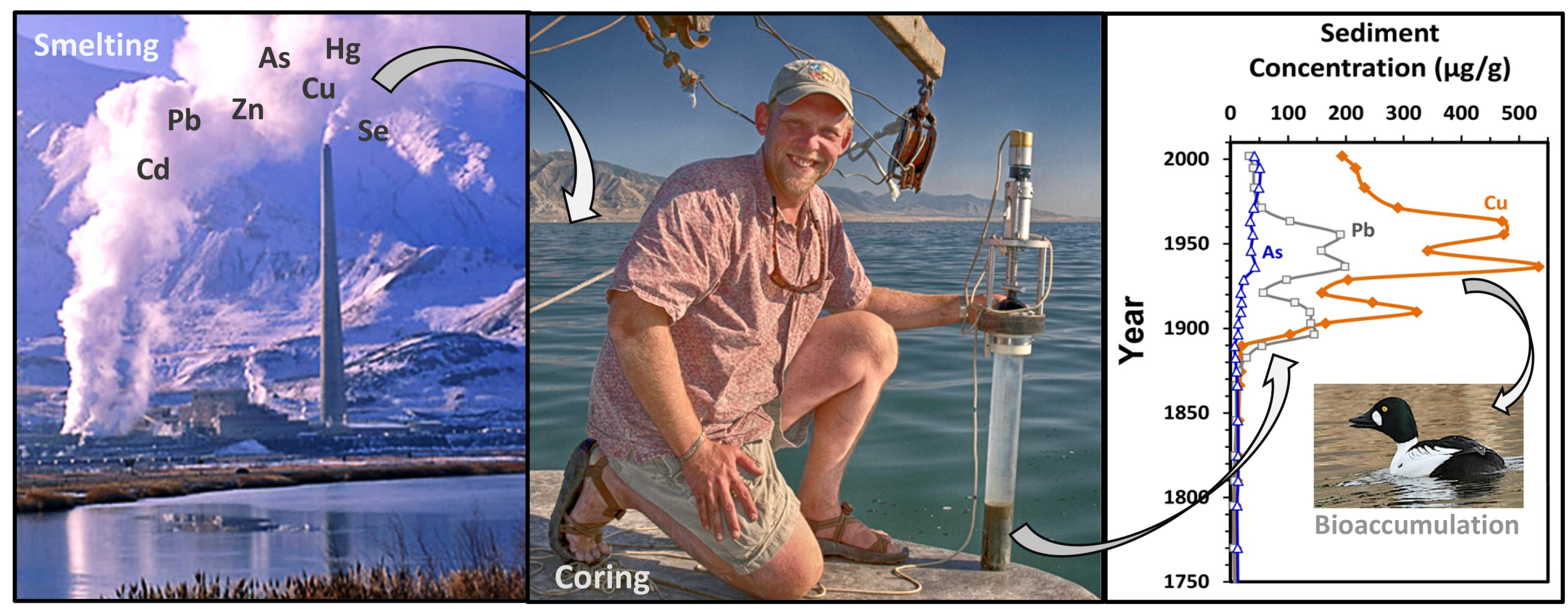




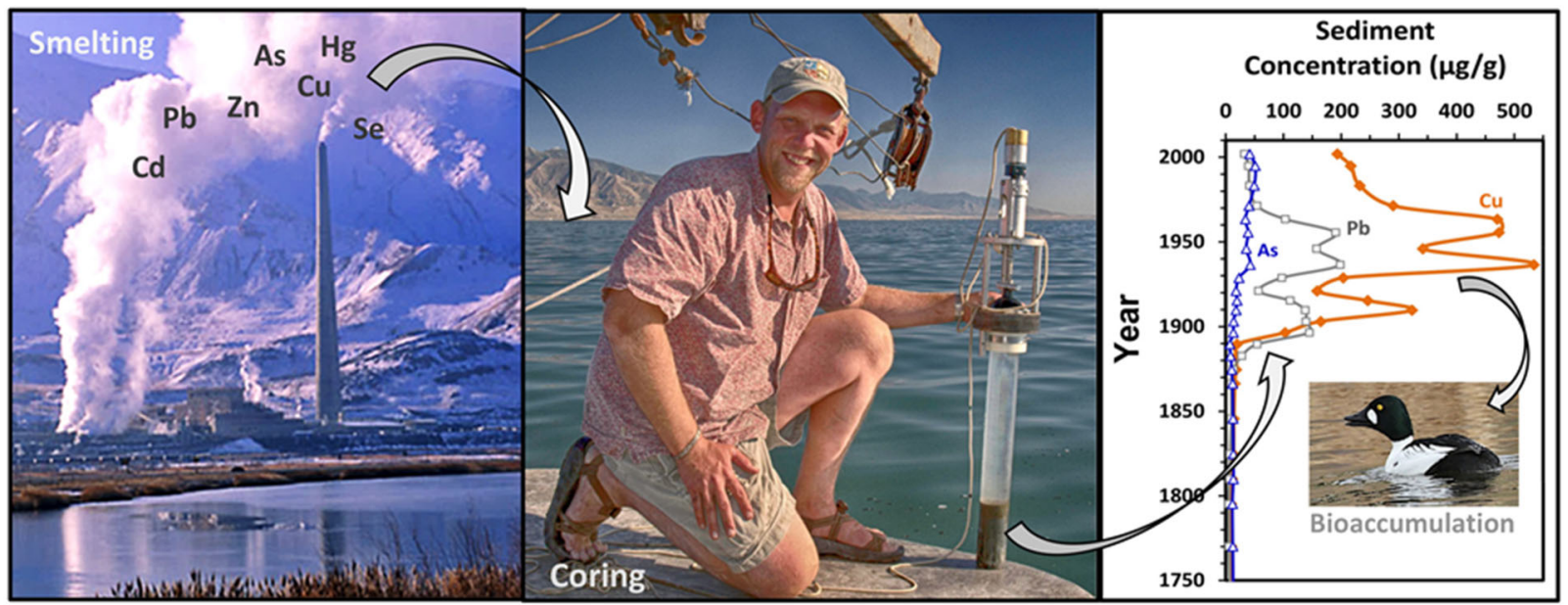

Graphic Abstract

4 contamination of a model saline ecosystem, Great Salt Lake, Utah

Wayne A. Wurtsbaugh ${ }^{1^{*}}$, Peter R. Leavitt ${ }^{2,3}$, Katrina A. Moser $^{4}$

${ }^{1}$ Dept. of Watershed Sciences and the Ecology Center, Utah State University, Logan, UT, USA,

\section{Effects of a century of mining and industrial production on metal}

(1)

(1)

112 Institute of Environmental Change and Society, University of Regina, Regina, Saskatchewan

$12 \quad$ Canada S4S 0A2 peter.leavitt@uregina.ca

13 [3nstitute of Global Food Security, Queen's University Belfast, Belfast, Antrim, Northern

14 Ireland, United Kingdom. P.leavitt@qub.ac.uk

$15{ }^{4}$ Dept. of Geography, The University of Western Ontario, London, Ontario, Canada, N6A 5C2,

$16 \quad$ kmoser@uwo.ca 


\section{Highlights}

18 - Sediments in Great Salt Lake were contaminated by mining beginning in the late 1800s.

19 - Metals in the sediments have declined since 1950 due to salt-density stratification.

20 - Additional recovery occurred after implementation of the 1963 U.S. Clean Air Act.

21 - Most metals, however, remain high and threaten the lake's abundant bird population. 


\section{Abstract}

24 Effects of mining and metals production have been reported in freshwater lake sediments from

25 around the world but are rarely quantified in saline lake sediments, despite the importance of

26 these lake ecosystems. Here we used dated sediment cores from Great Salt Lake, Utah, USA, a

27 large saline lake adjacent to one of the world's largest copper mines, to measure historical

28 changes in the deposition of 22 metals. Metal concentrations were low prior to the onset of

29 mining in the catchment in $1860 \mathrm{CE}$. Concentrations of copper, lead, zinc, cadmium, mercury

30 and other metals began increasing in the late 1800s, with peaks in the 1950s, concomitant with

31 enhanced mining and smelting activities. Sedimentary metal concentrations in the 1950s were

32 20-40-fold above background levels for copper, lead, silver and molybdenum. Concentrations of

33 most metals in surficial sediments have decreased 2-5-fold, reflecting: 1) storage and

34 mineralization of sedimenting materials in a deep brine layer, reducing metal transport to the

35 sediments; 2) improved pollution control technologies, and; 3) reduction in mining activity

36 beginning in the 1970s and 1980s. Despite reductions, concentrations of many metals in surficial

37 sediments remain above acceptable contamination thresholds for aquatic ecosystems with

38 migratory birds, and consumption advisories for mercury have been placed on three waterfowl

39 species. The research also highlights that metal deposition in saline lakes is complicated by

40 effects of hypersaline brines and deep-water anoxia in regulating sediment redox and release of

41 metals to surface waters. Given the importance of saline lakes to migratory birds, metals

42 contamination from mining and metals production should be a focus of saline lake remediation. 


\section{Capsule}

44 A paleolimnological analysis documented historical metal contamination in North America's largest

45 saline lake. Environmental controls and salinity stratification reduced sediment contamination, but 46 pollution still threatens migratory birds.

47

48 Keywords: paleolimnology; pollution; selenium; mercury; monimolimnion 


\section{Introduction}

Mining and industrial activities frequently release toxic metals to lakes directly through

51 waterways (Moore et al., 1991) and indirectly via atmospheric deposition (Nriagu et al., 1982).

52 Some metals biomagnify through food webs, causing harm to the biota and humans who

53 consume aquatic organisms (Suedel et al., 1994). Historical patterns and effects of metal

54 contamination have been recorded globally in the sediments of many aquatic systems (e.g. Child

55 et al., 2018; Ek and Renberg, 2001; Jin et al., 2013; Schuh et al., 2019). While the chronology

56 and magnitude of metals contamination has been recorded for freshwater lakes and estuaries (e.g.

57 Gawel et al., 2014; Leppänen et al., 2017; Thienpont et al., 2016), sedimentary studies are

58 seldom done in saline lakes (e.g. Naftz et al., 2000).

Metal contamination in saline lakes is of concern because these lakes are important

60 habitats for migratory waterfowl (Ashbaugh et al., 2018; Conover and Vest, 2009; Wurtsbaugh et

61 al., 2011). In some cases, metal contamination can be reduced by volatilization (Diaz et al.,

62 2009b) or by deflations of aerosols and dust particles from exposed lake beds or shorelines

63 (Erdinger et al., 2004; Goudie, 2014); however, lack of surface outflow in hydrologically-closed

64 (endorheic) basins may result in greatly elevated levels of metals in water and sediments (Javor,

65 1989). Further, many saline lakes have high solute concentrations (e.g., sulfate) which influences

66 metal, solubility, chelation, sedimentation and permanent sequestration (Blomqvist et al., 2004;

67 Hamilton-Taylor and Davison, 1995) Hypersaline lakes may also lack burrowing invertebrates

68 that otherwise can remobilize metals and alter interpretation of historical pollution patterns (e.g.

69 Chaillou et al., 2003).

Saline lakes may be particularly influenced by industrial and mining activities, as

71 terminal basins are often the main recipient of mining wastewater in arid regions. For example, 
72 the Great Salt Lake (GSL), Utah USA, is adjacent to major mining and smelting activities, and a

73 large industrial metropolitan area (Hughes, 1990). Mining for silver, lead and gold began in the

74 nearby Wasatch Mountains ca. 1863 (Ege, 2005; McPhee, 1977; Varley et al., 1921), while the

75 Bingham Canyon Mine of the Oquirrh Mountains (Kennecott Mine in Fig. 1), which is

76 historically one of the world's largest producers of copper and other metals, opened in 1905.

77 The smelter for this mine is now located on the south shore of GSL, while additional smelters

78 were located in the Salt Lake Valley (Hughes, 1990). To the north in Idaho and Utah, large strip

79 mines extract phosphate within the Bear River watershed (Mars and Crowley, 2003), the largest

80 source of water for GSL (Mars and Crowley 2003). These mines release selenium (Hamilton

81 and Buhl, 2005). Metallurgical plants, railroad maintenance, petroleum refining and other urban

82 manufacturing also release metals into the GSL and airshed (EPA, 2003), leading to potentially

83 toxic levels of metal pollution in the largest lake of the western USA.

Sediment cores from mountain lakes west of GSL have documented regional metal

85 contamination from smelting and industry and its effects (Kada et al., 1994; Reynolds et al.,

86 2010), whereas the absence of fish in GSL has limited concerns about biological accumulation in

87 its food webs. However, in recent years managers have found mercury, selenium and other

88 metal contamination in the GSL aquatic food chain, potentially, affecting large populations of

89 migratory waterfowl that use the lake as a staging habitat (Aldrich and Paul, 2002). For

90 example, Adams et al. (2015) documented elevated selenium and other metals in the brine

91 shrimp and brine flies that are important food sources for aquatic birds (Aldrich and Paul, 2002;

92 Roberts, 2013). In fact, a survey of metals and toxins in the surficial sediments of GSL and its

93 wetlands (Waddell et al., 2009) revealed metals concentrations frequently above Threshold

94 Effects Concentrations (TEC) detrimental to freshwater organisms (MacDonald et al., 2000). 
To help understand the history and magnitude of metal contamination in the Great Salt

96 Lake, we compared sedimentary profiles of metals in cores from the south arm of the lake

97 (Gilbert Bay, Fig. 1) to records of regional mining activity. Sedimentary analysis over a 200-

98 year interval provided baseline estimates of metal deposition in the ecosystem, as well as

99 evidence of the timing, magnitude and recovery from mining activities. Additionally, surface

100 sediments were analyzed from six other sites in the lake to assess the spatial gradient of current

101 contamination. This research on the GSL is a model for defining the fate of metal contaminants

102 in other saline lakes and help protect their aquatic food webs.

103

104 2. Study Site and Methods

105 2.1. Study Site

106

The Great Salt Lake (Fig. 1), at $5200 \mathrm{~km}^{2}$, is the largest lake in the western United States

107 and the largest saline lake in North America. GSL is a hydrologically-closed basin in Utah, USA

108 (41.04 N, -112.28 W), bordered on its eastern and southeastern shores by the Salt Lake City

109 metropolitan area with over two million residents. The lake is impacted by industrial and

110 municipal discharges, as well as by transportation causeways that divide the system into four

111 large bays (Fig. 1).

112 Regional human population and accompanying industrial development has increased

113 progressively from 8,000 inhabitants in 1850 to $2,380,000$ by 2020 . In 1922 , the Northwest Oil

114 Drain was connected to a sewer canal to discharge wastes from refineries and other industries in

115 Salt Lake City into Farmington Bay (Fig. 1), turning the canal into an EPA Superfund Cleanup

116 Site (EPA, 2003). 
The main body of GSL was bisected by a railway causeway constructed in 1959 .

118 Culverts and a breach allow exchange of water and salts between the two sub-basins; however,

119 salinity of northern Gunnison Bay $\left(1500 \mathrm{~km}^{2}\right)$ is normally at saturation (ca. $\left.330 \mathrm{~g} \mathrm{~L}^{-1}\right)$, whereas

120 the southern arm, Gilbert Bay $\left(2090 \mathrm{~km}^{2}\right)$, varies from 60 to $330 \mathrm{~g} \mathrm{~L}^{-1}$ depending on

121 meteorology, lake level and river diversions (Wurtsbaugh et al., 2017). At a lake elevation of

$1221280 \mathrm{~m}$, the mean and maximum depths of Gilbert Bay are 4.4 and $10.1 \mathrm{~m}$, respectively (Baskin,

123 2005). Gilbert Bay now receives an underflow of saturated brine from Gunnison Bay, so that,

124 since 1959, half of the southern bay has been underlain by a deep brine layer (monimolimnion)

125 with high concentrations of hydrogen sulfide (Jones and Wurtsbaugh, 2014).

The two bays on the eastern side of GSL receive freshwater from the Wasatch and Uinta

127 mountains, resulting in salinities that vary spatially and seasonally from freshwater to

128 hypersaline conditions. Farmington Bay $\left(\sim 310 \mathrm{~km}^{2}\right)$ in the southeast is shallow (mean depth 1.1

$129 \mathrm{~m}$ at $1280 \mathrm{~m}$ above sea level) and is partially-isolated from Gilbert Bay by an automobile

130 causeway constructed in 1952. Northeastern Bear River Bay $\left(212 \mathrm{~km}^{2}\right)$ has a mean depth of 0.6

$131 \mathrm{~m}$ at mean lake elevation and because of inflows from the Bear River, is a freshwater habitat for

132 much of the year (Johnson et al., 2019).

Water quality conditions differ markedly among bays in GSL (Wurtsbaugh et al., 2012).

134 Farmington Bay is hypereutrophic (mean chlorophyll $a 141 \mu \mathrm{g} \mathrm{L}^{-1}$ ), whereas hypersaline Gilbert

135 Bay (100-160 $\mathrm{g} \mathrm{TDS} \mathrm{L}^{-1}$ ) is less productive (winter Chl. $a \sim 70 \mu \mathrm{g} \mathrm{L}^{-1}$ ), particularly during

136 summer when grazing by abundant brine shrimp, Artemia franciscana, decreases concentrations

137 to ca. $1 \mu \mathrm{g} \mathrm{L}{ }^{-1}$ (Wurtsbaugh, 1992). Brine fly larvae (Ephydra spp.) are the only benthic

138 metazoan. GSL brine is composed of $55 \% \mathrm{Cl}, 28 \% \mathrm{Na}, 8 \% \mathrm{SO}_{4}, 4 \% \mathrm{Mg}$ and $5 \%$ other salts

139 (Sturm, 1980). Oxygen concentrations in Gilbert Bay are usually near saturation in the mixed 
140 layer, but are anoxic in the deep brine layer below $\sim 6.5 \mathrm{~m}$. Surface water temperatures reach

$14124^{\circ} \mathrm{C}$ in summer and can decline to $0^{\circ} \mathrm{C}$ or below in winter. The $\mathrm{pH}$ is relatively stable around

1428.1 in the mixed layer (Wurtsbaugh and Marcarelli, 2006). Total mercury and selenium

143 concentrations in the mixed layer of Gilbert Bay are near $5 \eta \mathrm{g} \mathrm{L}^{-1}$ and $0.5 \mu \mathrm{g} \mathrm{L}-1$, respectively,

144 but mercury concentrations can reach $>60 \eta \mathrm{L} \mathrm{L}^{-1}$ deep brine layer (Jones et al., 2009; Jones and

145 Wurtsbaugh, 2014). Water quality is better in Bear River Bay with mean Chl. $a \sim 22 \mu \mathrm{g} \mathrm{L} \mathrm{L}^{-1}$

146 (Wurtsbaugh, 2012) and total selenium levels of $\sim 0.5 \mu \mathrm{g} \mathrm{L}^{-1}$ (Naftz et al., 2009). Less is known

147 about the water quality of Gunnison Bay, other than that salinities are usually near saturation and

148 metazoans are rare (Baxter and Butler, 2020).

1492.2 Sediment collection and chronology

150 Eight sites were sampled (Fig.1, Table S1) in 2009 and short $(<75 \mathrm{~cm})$ cores were

151 collected with a Kajak-Brinkman gravity corer (Glew et al., 2001). Cores were sectioned into 5-

$152 \mathrm{~mm}$ increments in the field using a Glew extruder (Glew et al. 2001). We provide dated

153 stratigraphies from two sites (Gilbert Bay 3 and 4), and comparison of metal content from the

154 upper $0-1 \mathrm{~cm}$ from all sites to estimate spatial variation across GSL. The two cores from Gilbert

155 Bay were collected from water depths $>7 \mathrm{~m}$ where an anoxic deep brine layer was present. These

156 regions were known to have a high rate of sediment deposition (Oliver et al., 2009).

157 Estimates of radioisotope activity were performed on 12-14 samples per core at

158 University of Regina following Bunting et al. (2016). Sediment dating was based on ${ }^{210} \mathrm{~Pb}$

159 activity measured by gamma spectrometry (Appleby and Oldfield, 1983; Schelske et al., 1994)

160 using an Ortec High-Purity Germanium (HPGe) Coaxial Well Photon Detector System. ${ }^{137}$ Cs

161 activity was measured at $661.7 \mathrm{keV}$ to identify the period of maximum fallout from atmospheric 
162 nuclear weapons testing and validate ${ }^{210} \mathrm{~Pb}$ dates. Sediment age-depth relations were calculated

163 using the CRS (constant rate of supply) model (Appleby and Oldfield, 1983).

\subsection{Analytical Methods for Metals}

165 Sediment subsamples from each core slice were oven-dried at $70^{\circ} \mathrm{C}$ until a constant

166 weight. Metal concentrations in the sediment samples were measured at the Utah Veterinary

167 Diagnostic Laboratory (http://www.usu.edu/uvdl/) in Logan, Utah. The nitric acid leachable

168 mineral concentrations in each slice were quantified using inductively coupled plasma mass

169 spectroscopy (ICP-MS). Briefly, weighed sediment samples $(\sim 0.5 \mathrm{~g})$ were digested at $90^{\circ} \mathrm{C}$ in

$170 \quad 10-\mathrm{ml}$ trace mineral grade nitric acid for $4 \mathrm{hr}$. to estimate environmentally available metals (EPA,

171 1996). Digests were diluted 1:20 with $18.2 \mathrm{mOhm}$ ultrapure water to provide a $5 \%$ nitric acid

172 matrix and analyzed along with multiple standards. A quality control (QC) sample was analyzed

173 with every five sediment samples and values that were not within $5 \%$ of targets were re-

174 analyzed. A small number of samples for silver yielded values below detection limits. For

175 these we assumed that concentrations were $80 \%$ of the detection limit because adjoining samples

176 in the cores had values just slightly over the detection limit.

177 Sedimentary metal concentrations were expressed as mass $\mathrm{g}^{-1}$ dry matter, following

178 correction for salt content in interstitial waters. The salt correction was particularly important in

179 the uppermost 3-6 $\mathrm{cm}$ of the Gilbert Bay cores because unconsolidated sediments were rich in

180 salts. Sodium (Na) concentrations in the different sections of Gilbert Bay cores were highly

181 correlated with water content (x):

$$
[\mathrm{Na}]=0.957 \mathrm{x}+0.0612 ; \quad \mathrm{R}^{2}=0.928, \mathrm{n}=57
$$


183 This equation, and the relationship between $\mathrm{Na}$ and total salt in Gilbert Bay water $(0.30 \mathrm{~g} \mathrm{Na}: 1 \mathrm{~g}$

184 salt; Sturm, 1980), was used to estimate the interstitial salt content. After correction, metal

185 concentrations prior to 1860 were assumed to represent background levels and were used to

186 calculate enrichment factors for metals in more recent strata. Here we focus on 11 metals that

187 were either deposited in high concentrations or which are known to have high toxicity to biota.

\subsection{Metal Enrichment Factors and Criteria}

We calculated metal enrichment indices to easily compare contamination histories among metals following Hokanson (1980) and Belzile et al. (2004), Maximum Enrichment Factors were

191 calculated as the maximum sedimentary metal concentration relative to mean values recorded

192 prior to industrialization (pre-1860). Current Enrichment Factors were estimated as the ratio of

193 the mean concentration in the uppermost $1 \mathrm{~cm}$ relative to the same background values. All

194 indices were estimated from ratios of each metal to that of aluminum, a conservative tracer of

195 watershed erosion (Engstrom and Wright, 1984). This approach assumes most metals are derived

196 from atmospheric, fluvial or direct industrial sources, rather than eroded materials. Unlike other

197 metals, sedimentary concentrations of erosion-indicators aluminum and iron did not change

198 markedly in either core (Tables S2a, b). To provide some context for understanding the potential

199 risks associated with concentrations of metals in GSL sediments, we have used freshwater

200 sediment Threshold Effects Concentrations (TEC) where some impacts on biota may be possible, 201 and Probable Effects Concentrations (PEC) where impacts are likely (MacDonald et al., 2000).

\subsection{Historical Production of Metals in Utah}

Records of the annual production of commercial metals within the State of Utah were

204 obtained from the Utah Geological Survey (2011). Most minerals were processed in Salt Lake

205 Valley or the Tintic/Mercur mining districts 40-90 km south of GSL (Fig. 1; Ege, 2005). 
206 Although small amounts of mercury have been mined in Utah, residues in the lake likely

207 originated from imported mercury used to extract gold and silver with the mercury amalgamation

208 process, Hg released during smelting of deposits containing lead and zinc (Plumlee et al., 1996),

209 and local industrial sources. Consequently, although not ideal, we have used the annual

210 extraction of lead as a metric for mercury use and production in Utah. Although metal smelting

211 is frequently associated with atmospheric deposition of acids, GSL lies within watershed

212 underlain primarily by limestone and is therefore well buffered (Ellis, 1986).

\section{3. Results}

\subsection{Sediment Chronology}

216 At Gilbert Bay's core site $4,{ }^{210} \mathrm{~Pb}$ declined in a monotonic fashion to background levels, 217 whereas at site 3 , an intermediate peak was noted at $\sim 6 \mathrm{~cm}$ depth, possibly representing a change 218 in sediment rate (Fig. S1). Distinct peaks of ${ }^{137} \mathrm{Cs}$ were recorded in both cores but maximal 219 specific activities of ${ }^{137} \mathrm{Cs}$ in the early 1960 s were recorded only at site 4 , consistent with high 220 deposition of this isotope from open-air tests of atomic weapons ( 1964). In contrast, maximal

$221{ }^{137} \mathrm{Cs}$ activity at site 3 appears to precede expected dates by $10-20 \mathrm{yr}$., either due to isotope

222 migration, low sampling resolution (1 sample per $\sim 15$ years), or difficulty fitting ${ }^{210} \mathrm{~Pb}$

223 regressions due to a mid-core peak of ${ }^{210} \mathrm{~Pb}$. At both sites 3 and $4,{ }^{137} \mathrm{Cs}$ activities declined to 224 near baseline values in surface sediments, suggesting relatively low levels of sediment mixing 225 and post-depositional ${ }^{137} \mathrm{Cs}$ migration. Taken together, the radioisotopes suggest a more reliable 226 chronology for site 4. 


\subsubsection{Temporal variation of sediment contamination}

Analyses of Gilbert Bay cores indicated that many metals (e.g., $\mathrm{Cu}, \mathrm{Hg}, \mathrm{Pb}, \mathrm{Zn}$ ) began

231 increasing in the sediment record in the late 1800s and early 1900s concomitant with mining and

232 smelting activities, before peaking in the mid-1950s and declining in more recently-deposited

233 sediments (Fig. 2, Table S2a, S2b). For example, at both core locations $\mathrm{Cu}$ concentrations rose

234 steadily from background levels of $11 \mu \mathrm{g} \mathrm{g}^{-1}$ dry mass (hereafter $\mu \mathrm{g} \mathrm{g}^{-1}$ ) before the onset of

235 commercial mining, to concentrations of $500 \mu \mathrm{g} \mathrm{g}^{-1}$ when copper extraction reached 250,000

236 metric tons per year in the 1950s. Since the 1950-1960s, concentrations of copper in the

237 sediment record have decreased markedly, although values in surficial sediments are still 10-20

238 times higher than background levels. Note that sedimentary $\mathrm{Cu}$ declines continue despite an

239 overall increase in copper smelting in the past two decades.

Unlike most metals, concentrations of selenium and arsenic have not declined in recent

241 years (Fig. 3). Background concentrations of Se were $\sim 1 \mu \mathrm{g} \mathrm{g}^{-1}$ at both sites and did not increase

242 substantially until the 1930s-1950s. Since then, sedimentary Se has remained at a relatively

243 constant concentration of 4-6 $\mu \mathrm{g} \mathrm{g} \mathrm{g}^{-1}$. Background levels of arsenic were $\sim 13 \mu \mathrm{g} \mathrm{g}^{-1}$ and began

244 increasing in the late $1800 \mathrm{~s}$ to $30-50 \mu \mathrm{g} \mathrm{g}^{-1}$.

245 Enrichment factors all metals increased from pre-industrial levels to peaks during the

246 mid-20 ${ }^{\text {th }}$ century, and most declined in recent decades (Fig. S2). Silver and copper in the cores

247 showed the highest enrichment factors, with values $>40$-fold above background, while those of

$248 \mathrm{~Pb}$, Mo and $\mathrm{Cd}$ ranged from 15-35 and $\mathrm{Hg}$ was 12-fold higher. In contrast, $\mathrm{Se}$, $\mathrm{Zn}$ and As all had

249 maximum factors less than 6. Current enrichment factors for six (As, $\mathrm{Zn}, \mathrm{Se}, \mathrm{Hg}, \mathrm{Sn}, \mathrm{Cu}$ ) of the

25011 metals are less than $50 \%$ of the historical maximum enrichment factors and all metals still 
251 have 3-18-fold higher concentrations than background (Fig. 4). Concentrations of $\mathrm{Zn}$, As and Se

252 have all decreased marginally, or not at all, compared to the historical maximum enrichment

253 factors.

\section{3.2.2 Spatial variation of sediment contamination}

From an ecosystem health perspective, the most relevant metal concentrations are those

256 at the sediment-water interface, as they are the ones that potentially diffuse into the water column

257 and are subject to feeding upon by macroinvertebrates and birds. Spatial analysis of the surface

258 sediments indicates that many metals in Gilbert and Farmington Bays remain above TEC

259 established for freshwaters (MacDonald et al., 2000), whereas Bear River Bay sediments were

260 less contaminated than other GSL sites (Table 1). Sites 1, 4 and 7, closest to smelter locations

261 and other pollution sources (Figs. 1, 5), had the highest concentrations of metals, which usually

262 exceeded TEC levels and often PEC levels (Table 1; Fig. 5). Selenium exceeded the freshwater

263 TECs and PECs most frequently (Table 1), with high concentrations at all three sites in Gilbert

264 Bay. Selenium also exceeded the TEC, but not the PEC, at all three sites in Farmington Bay,

265 whereas Bear River Bay sediments exceeded TEC at only one site. Copper and As

266 concentrations exceeded TECs throughout Gilbert and Farmington bays but not at Bear River

267 Bay. Surficial mercury concentrations exceeded the TEC at five of the six sites in Gilbert and

268 Farmington Bays, but not in Bear River Bay deposits. Cadmium, $\mathrm{Pb}$ and $\mathrm{Zn}$ concentrations were

269 above TECs at one or more sites in Gilbert and Farmington bays. 
Table 1. Average concentrations ( $\mu \mathrm{g} \mathrm{g}^{-1} \mathrm{dry}$ ) of metals in the top 1-cm of cores taken in three bays of the Great Salt Lake. Threshold effects concentrations (TEC) and the probable effects concentrations (PEC) (McDonald et al. 2000) are also shown. For silver, the Washington State Standard (2013) is shown as a TEC. Lake sediment concentrations exceeding the TECs are shown in bold numerals, and those exceeding the PECs are underlined.

\begin{tabular}{|c|c|c|c|c|c|c|c|c|c|c|}
\hline \multirow[b]{2}{*}{ Metal } & \multicolumn{2}{|c|}{ Toxicity Criteria } & \multicolumn{3}{|c|}{ Gilbert Bay } & \multicolumn{3}{|c|}{ Farmington Bay } & \multicolumn{2}{|c|}{ Bear River Bay } \\
\hline & TEC & PEC & 3 & 4 & 5 & 1 & 2 & 7 & 6 & 9 \\
\hline & \multicolumn{10}{|c|}{ Metals exceeding threshold effect concentrations (TEC) at one or more sites } \\
\hline Selenium & 1.0 & 4.0 & $\underline{4.9}$ & $\underline{4.9}$ & $\underline{4.3}$ & 2.2 & 3.3 & 2.0 & 1.1 & 0.7 \\
\hline Copper & 32 & 149 & 109 & $\underline{205}$ & 91 & 133 & 42 & 126 & 16 & 16 \\
\hline Zinc & 121 & 459 & 80 & 124 & 47 & 242 & 68 & 195 & 43 & 35 \\
\hline Lead & 36 & 128 & 34 & 58 & 21 & 119 & 25 & 79 & 18 & 15 \\
\hline Arsenic & 10 & 33 & 25 & $\underline{46}$ & 18 & 17 & 12 & 20 & 7 & 5 \\
\hline Cadmium & 1.0 & 5.0 & 1.2 & 2.4 & 0.7 & 2.5 & 0.8 & 2.4 & 0.4 & 0.4 \\
\hline Mercury & 0.18 & 1.06 & 0.12 & 0.41 & 0.30 & 0.81 & 0.18 & 0.63 & 0.04 & 0.05 \\
\hline \multirow[t]{2}{*}{ Silver } & 0.6 & & 0.02 & 0.07 & $<0.03$ & 1.71 & 0.10 & 1.89 & 0.08 & 0.13 \\
\hline & \multicolumn{10}{|c|}{ Other Metals } \\
\hline Cobalt & & & 3.3 & 4.3 & 1.6 & 5.0 & 1.5 & 4.0 & 4.0 & 4.0 \\
\hline Chromium & 43.4 & 111.0 & 9.1 & 11.4 & 6 & 32.3 & 6.7 & 22.0 & 8.8 & 7.2 \\
\hline Molybdenum & & & 34.7 & 16.7 & 21.6 & 1.1 & 18.7 & 1.0 & 0.4 & 0.1 \\
\hline Nickel & 22.7 & 48.6 & 10.0 & 14.1 & 6.5 & 11.6 & 7.2 & 13.1 & 12.5 & 9.6 \\
\hline Antimony & & & 0.43 & 0.64 & 1 & 0.04 & 0.43 & 0.05 & 0.03 & 0.02 \\
\hline Tin & & & 0.83 & 1.64 & 0.62 & 2.53 & 0.43 & 1.67 & 0.03 & 0.02 \\
\hline Titanium & & & 0.42 & 0.83 & 1.40 & 0.40 & 1.37 & 0.34 & 0.46 & 0.32 \\
\hline Vanadium & & & 14.7 & 19.5 & 9.7 & 19.9 & 10.2 & 19.6 & 9.1 & 8.2 \\
\hline
\end{tabular}




\section{Discussion}

273

274

275

276

277

278

279

280

281

282

283

284

285

286

287

288

289

290

291

292

293

294

\subsection{Historical Trends of Metals}

Paleolimnological analyses showed that the onset of metal contamination was concomitant with mining and metals production in the lake's watershed. Further, patterns of spatial distribution of metals showed that sites proximal to mines and smelters hade greater contamination than those distant to the sources. The chronology of metal contamination in GSL sediments is consistent with those described for the Uinta Mountain lakes, 90-155 km east of GSL (Kada et al., 1994; Moser et al., 2010; Reynolds et al., 2010), suggesting the same source. Isotopic analyses of $\mathrm{Pb}$ in Uinta Mountain lake sediments showed that the contamination there was due to smelting in Midvale located $15 \mathrm{~km}$ south of Salt Lake City and the Bingham Canyon Kennecott mine (Reynolds et al. 2010). Increases in most metal concentrations in GSL sediments were usually 2-3-fold greater than those observed in the Uinta Lakes, while $\mathrm{Cu}$ deposition was 15 -fold greater. Contaminants of Uinta Mountain lakes arrive atmospherically (Reynolds et al., 2010), so differences with GSL likely reflect a combination of greater transportation distance and local pollution via runoff at GSL. While we cannot separate these mechanisms in this paper, Couillard et al. (2008) noted a similar a difference in contamination of lakes located proximate to source of metal pollution and those $30 \mathrm{~km}$ distant that received only atmospheric influx.

Periodic releases of material from a Kennecott/Rio Tinto tailings pond (Fig. 1) $500 \mathrm{~m}$ from the south shore of GSL may have contributed irregularly to the metals loading of proximal Site 4. Historical records indicate that tailings pond dikes failed in 1941-42, 1944, 1951, 1964 and 1969, although it is unclear how much material entered GSL (EPA, 2002). Additionally, in 1965, an experimental tailings capture system failed when a south-shore dike containing 56,000 
$295 \mathrm{~m}^{3}$ of Kennecott tailings material was destroyed by wave action (EPA, 2002). Typical tailings

296 material at that site contains $\sim 30 \mu \mathrm{g} \mathrm{g}^{-1} \mathrm{As}, \sim 240 \mu \mathrm{g} \mathrm{g}^{-1} \mathrm{~Pb}$ and $\sim 6 \mu \mathrm{g} \mathrm{g}^{-1} \mathrm{Se}$. If this material was

297 spread over just $25 \%$ of the southern area of Gilbert Bay, it would have deposited a layer about

$2980.8 \mathrm{~mm}$ thick elevating metal concentrations in the sediments for several years.

299 Mercury concentrations in the lake's sediments are particularly alarming, given that

300 methylmercury concentrations in the lake's deep brine layer are among the highest recorded in

301 the USA (Naftz, 2008) . Like many metals, Hg concentrations in Gilbert Bay sediments declined

302 from the mid-20 $0^{\text {th }}$ century maxima. Current atmospheric deposition of $\mathrm{Hg}$ to GSL is not

303 abnormally high (Peterson and Gustin, 2008), consequently, we infer that more recent reductions

304 in sedimentary Hg largely reflect diminished legacy effects of early mining activities and,

305 possibly, formation of the deep brine layer (see below).

306 Improved smelting techniques and, in some cases, lower metal production, likely

307 contributed to declines in sedimentary metal concentrations since the mid- $20^{\text {th }}$ century. Lead and

308 Zn production in Utah ceased ca. 1980, consistent with modern sediment concentrations of ca.

$30922-33 \%$ and ca. $45-53 \%$ of the peaks in the 1940 s and 50 s, respectively. Similarly, the use of

310 lead in gasoline peaked in the early 1970s and has declined to near zero (Laws, 1993). In

311 contrast, $\mathrm{Cu}$ production in Utah has increased to record levels, so the decreases in sedimentary

$312 \mathrm{Cu}$ to $33-42 \%$ of historical maximum (Figs. 2, 4) likely reflects improved industrial practices.

313 Atmospheric pollution declined markedly with the Clean Air Act of 1963 and subsequent

314 amendments in the 1970s, while an improved economic market for recovered sulfur also reduced

315 industrial discharges. As a result of emission controls and economic factors, Kennecott Copper

316 (now Rio Tinto), has reduced emissions of sulfuric acid from $\sim 22 \mathrm{MT} \mathrm{h}^{-1}$ in 1974 to $\sim 0.03 \mathrm{MT} \mathrm{h}^{-}$

$317{ }^{1}$ by 1998 (Newman et al., 1999). Additionally, a 370-m smokestack built in 1974 helps disperse 
318 metals away from GSL. Consistent with enhanced atmospheric dilution, sediment $\mathrm{Cu}$

319 concentrations in GSL have decreased $\sim 50 \%$ relative to peak values (Fig. 4), whereas those in

320 Uintah Mountain lakes 85-100 km downwind have exhibited negligible decreases (c.f. Fig. 6 and

321 Reynolds et al., 2010).

322 Although improved smelting techniques and, in some cases, lower metal production

323 likely contributed to declines in sedimentary metal concentrations, most metals in the sediments

324 of GSL began to decline ca. 1950 before the advent of these changes (Site 4; Figs. 2, S1).

325 Instead, declines are coeval with construction of the Southern Pacific railway causeway in 1959

326 which bisected GSL and led to the formation of the deep brine layer in Gilbert Bay (Domagalski

327 and Eugster, 1990; Johnson et al., 2019). This dense, anoxic brine layer is usually present below

328 a depth of $\sim 6.5 \mathrm{~m}$, and has a density (up to $1.2 \mathrm{~g} \mathrm{~cm}^{-3}$ ) greater than that of many phytoplankton

329 and detrital particles (Reynolds, 2006). As many metals reach the lake bottom via sedimentation

330 of phytoplankton and detritus (Maszczyk and Wurtsbaugh, 2017), this deep brine layer can

331 suspend material above the sediments, and allow mineralization and formation of dissolved

332 phases of in the deep water column. This hypothesized mechanism is supported by Jones and

333 Wurtsbaugh (2014) who reported that particulate carbon was 120-200-fold higher in the deep

334 brine layer than in the mixed layer of GSL, and dissolved mercury was 9-fold higher there.

335 Approximately $40 \%$ of metals in the deep brine water may be entrained into the upper mixed

336 layer each year (Jones and Wurtsbaugh, 2014), potentially reducing metals accumulation in

337 profundal deposits but exposing brine shrimp and other biota to $\mathrm{Hg}$ in the upper water column.

338 Deep brine layers have been reported in other saline lakes (Anderson, 1958; Miller et al., 1993;

339 Tiffany et al., 2007), but their effects on metal sedimentation and recycling have not previously

340 been investigated . 
The low redox potential $(<-200 \mathrm{mV})$ and abundant sulfides $\left(>100 \mathrm{mg} \mathrm{l}^{-1}\right)$ in the stagnant

342 brine layer (Jones and Wurtsbaugh, 2014) may have variable effects in metal deposition

343 (Domagalski and Eugster, 1990). These authors analyzed the metals in the water column and

344 sediments of GSL and concluded that the deep brine layer traps metals, but ultimately facilitates

345 the permanent storage of $\mathrm{Cu}, \mathrm{Zn}, \mathrm{Pb}$ and $\mathrm{Co}$ by co-precipitation with pyrite $\left(\mathrm{FeS}_{2}\right)$ in the anoxic,

346 reducing sediments. Although, Mo and Cd also precipitate as sulfides, these metals remain

347 mobile if exposed to oxidizing condition, but this has only occurred in 2014-15 (Yang et al.,

348 2019), after the time our cores were taken. Others working in both fresh and marine waters have

349 found that low redox potentials and high sulfide concentrations reduce the mobility of many of

350 the metals that we investigated (Engstrom and Wright, 1984; Hamilton-Taylor and Davison,

351 1995; Smrzka et al., 2019). These analyses suggest that the redox changes induced by formation

352 of the anoxic deep brine layer should have increased sedimentary concentrations of these metals,

353 whereas their concentrations have all decreased in recent decades (Figure 3; Appendix 1).

354 Although speculative, this points to a need for a greater understanding of metal movements

355 between sediments, brines and waters of saline lakes to ensure that technological changes are

356 reducing metals contamination of lake sediments.

357 In contrast to most metals, concentrations of the metalloids Se and As have increased or

358 remained relatively stable during the past 50 years (Fig. 3). Arsenic occurs in both the Mercur

359 gold ores and lead-zinc ores of western Utah. Selenium occurs at low levels in the Bingham

360 Canyon porphyry copper deposits and is released from smelting activity (Newman et al., 1999).

361 Although Se is also released into the Bear River watershed from phosphate mining districts in

362 Idaho and the Uinta Mountains (Hamilton and Buhl, 2005; Mars and Crowley, 2003), this river

363 provides only $26 \%$ of Se influx compared to riverine inputs from the Salt Lake Valley watershed 
364 (Diaz et al., 2009a). Instead, both As and Se are emitted from smelting activities in the Great

365 Salt Lake Valley, as demonstrated locally from tailings wastewater (EPA, 2002). Concentrations

366 of these metalloids, particularly As, were highest at coring site 4 which is closest to the

367 Kennecott smelter (Fig. 1) and discharge creeks, demonstrating a continued local source of

368 metalloids (Naftz et al., 2009). In addition, both As and Se are incorporated into insoluble pyrite

$369\left(\mathrm{FeS}_{2}\right)$ under highly reducing conditions $(-200 \mathrm{mV})$ (Rickard and Luther, 2007; Smrzka et al.,

370 2019) characteristic of the GSL's deep brine layer (Jones and Wurtsbaugh, 2014), suggesting

371 that local sources of contamination may be effectively trapped in the southern basin. Better

372 understanding of the mechanisms sustaining elevated levels of Se and As is needed because

373 surficial sediments in Great Salt Lake still exceed TEC and PCC values to harm aquatic wildlife

374 (Table 1).

375 Although concentrations of most metals in the Great Salt Lake's sediments have

376 declined, complete recovery will require many decades. For example, Haas et al. (2019)

377 demonstrated that $\sim 50$ years were needed after catchment abandonment in the case of a lake

378 polluted following Roman settlement. Jamieson (2014) found that copper concentrations in the

379 surface sediments of Yellowknife Lake (Canada) declined to baseline levels 25 years after

380 control of excessive emissions from nearby Giant Mine. Recovery in GSL appears to be even

381 slower. For example, in Utah commercial production of lead and automobile emissions nearly

382 ceased by 1981 but current $\mathrm{Pb}$ levels remain six- to nine-fold higher than background levels.

\subsection{Spatial distribution and toxicity of metals}

384 Concentrations of metals in the surface sediments varied widely in the three bays, with

385 those at the southern end of Farmington Bay and Gilbert Bay, closest to mining and smelting,

386 being the highest, and those in northeastern Bear River Bay the lowest. High concentrations of 
387 metals at Site 1 in Farmington Bay also may result from the proximity of this site to the outflow

388 of the combined Sewer Canal and the NW Oil Drain (Sorensen and others, 1988). Samples from

389 Bear River Bay generally had relatively low levels of contamination (Table 1), with only

390 selenium slightly exceeding TEC guidelines at one site. We infer that the low absolute

391 concentrations in Bear River Bay reflect greater distance to source, hydrological isolation by the

392 train causeway, and higher dilution by riverine materials (Allred and Judd, 2002).

393 Concentrations of most metals in southern most Gilbert and Farmington Bay surface

394 sediments exceeded their TECs, while $\mathrm{Cu}$, As, and Hg also exceeded PECs. These bays are a

395 critical stopover feeding area over millions of migratory birds represented by 257 species (Baxter

396 and Butler, 2020). Brine fly larvae and brine shrimp are important vectors that transfer metals to

397 migratory waterfowl, but these invertebrates are resistant to metal pollution (Brix et al., 2004).

398 Although exposure to metals above TEC and PEC values are consequently not a direct concern

399 for these species, trophic transfer to sensitive avian species remains a risk. Biomagnification

400 factors for $\mathrm{Se}$ and $\mathrm{Hg}$ in brine flies living in oxic environments are modest $(\mathrm{Hg}-2.2 \mathrm{X}$; $\mathrm{Se}$ -

401 1.2X; Wurtsbaugh et al., 2011). Nevertheless, recent analysis of GSL waterfowl revealed that

402 their eggs have Se and $\mathrm{Hg}$ levels exceeding toxicity benchmarks or regulatory standards

403 (Ackerman et al., 2015). Additionally, Hg concentrations in three local duck species exceed

404 human dietary thresholds, leading Utah to issue consumption advisories (Utah Department of

405 Environmental Quality, 2019). Thus, although concentrations of metals have declined in

406 lacustrine sediments, effects of ongoing and legacy contamination remain a threat to the millions

407 of birds utilizing GSL.

408 


\section{Conclusions}

Great Salt Lake is located next to major mining, smelting and industrial areas and its

411 sediments exhibited marked metal contamination. Although metal pollution in GSL generally

412 peaked in the mid-1950s and declined thereafter, many metal concentrations remain above

413 critical thresholds decades later. Declines in metal content of lake sediments over the past 75

414 years likely arise from multiple mechanisms including: (1) decreased mining for some elements

415 such as lead and zinc; (2) cleaner smelting technologies; , and; (3) formation of a deep brine layer

416 that produces reducing conditions and likely reduces sedimentation of metals. Concern remains

417 for $\mathrm{Cu}, \mathrm{Hg}, \mathrm{Cd}, \mathrm{Pb}, \mathrm{Zn}$, Se and $\mathrm{As}$, metals whose concentrations in surface sediments remain

418 both elevated above TEC and accessible to invertebrates supporting the food web of migratory

419 and regional birds. Notwithstanding the declining levels of many metals in the lake,

420 concentrations of As and Se were either stable or increasing in the sediments and we suggest that

421 lake managers should carefully monitor these metals to ensure that they do not increase to even

422 higher levels. Importantly, our research shows that even when environmental regulations

423 successfully lower metal pollution of saline lakes, there remain lingering legacy effects of these 424 pollutants.

\section{Acknowledgements}

427 Erin Fleming Jones, Ryan Choi, Dave Powelson, Zoraida Quinones-Rivera, David

428 Barnes, Katie Fisher, David Epstein, Michelle Kang, Jodi Gardberg, Jeff Ostermiller and Jeremy

429 Mears provided field and laboratory assistance. Bjoern Wissel conducted radioisotope analyses.

430 Erica Gaddis reconciled the project. Kenneth Krahulec and Elizabeth Palmer provided insights

431 on mining and ore processing history in Utah and Idaho. Joan McLean, William Johnson, and 
Tammy Rittenour provided valuable advice on metal mobility in sediments and core dating

433 procedures. Bruce Waddell and Nathan Darnall provided information on contaminants in the

434 Great Salt Lake. Johnnie Moore reviewed an early version of the manuscript. David Naftz

435 provided raw data and insights on contaminants from earlier cores taken in Farmington Bay and

436 nearby Decker Lake. Funding for the work was provided by the Utah Division of Water Quality,

437 The Natural Sciences and Engineering Research Council of Canada (PRL, KAM), the Canada

438 Research Chair program (PRL), Canada Foundation for Innovation (PRL, KAM), University of

439 Regina (PRL) and Queen's University, Belfast (PRL).

\section{Appendix A. Supplementary information}

Supplementary data and information related to this article can be found at http:// $\mathrm{xxxx}$

\section{REFERENCES}

Ackerman, J.T., Herzog, M.P., Hartman, C.A., Isanhart, J., Herring, G., Vaughn, S., Cavitt, J.F., EaglesSmith, C.A., Browers, H., Cline, C., Vest, J., 2015. Mercury and selenium contamination in waterbird eggs and risk to avian reproduction at Great Salt Lake, Utah U.S. Geological Survey Open-File Report 2015-1020, 164 p., http://dx.doi.org/10.3133/ofr20151020.

Adams, W.J., DeForest, D.K., Tear, L.M., Payne, K., Brix, K.V., 2015. Long-term monitoring of arsenic, copper, selenium, and other elements in Great Salt Lake (Utah, USA) surface water, brine shrimp, and brine flies. Environ. Monit. Assess. 187, 118.

Aldrich, T.W., Paul, D.S., 2002. Avian ecology of Great Salt Lake, in: Gwynn, J.W. (Ed.), Great Salt Lake: An overview of change. Utah Department of Natural Resources, Salt Lake City, pp. 343-374.

Allred, M.D., Judd, H.L., 2002. Lower Bear River watershed restoration action strategy: A sub-basin assessment for the Lower Bear River and Tributaries from GSL to Cutler reservoir in Box Elder County, Utah. Utah Department of Environmental Quality. https://geodata.geology.utah.gov/pages/view.php?search=\%21collection $104+\& k=\&$ modal=\&dis play=thumbs\&order by=collection\&offset=0\&per page=48\&archive=\&sort=ASC\&restypes=\&re centdaylimit=\&foredit $=\&$ ref $=8264$ (accessed $10 \mathrm{Apr} 2020$ ), Salt Lake City, p. 28.

Anderson, G.C., 1958. Some limnological features of a shallow saline meromictic lake. Limnol. Oceanogr. 3, 259-270.

Appleby, P.G., Oldfield, F., 1983. The assessment of Pb-210 data from sites with varying sediment accumulation rates. Hydrobiologia 103, 29-35. 
Ashbaugh, H.M., Conway, W.C., Haukos, D.A., Collins, D.P., Comer, C.E., French, A.D., 2018. Evidence for exposure to selenium by breeding interior snowy plovers (Charadrius nivosus) in saline systems of the Southern Great Plains. Ecotoxicology 27, 703-718.

Baskin, R.L., 2005. Calculation of area and volume for the south part of Great Salt Lake, Utah. U.S. Geological Survey Open File Report 2005-1327, U.S. Geological Survey Open File Report 20051327.

Baxter, B.K., Butler, J.K., 2020. Great Salt Lake biology: A terminal lake in a time of change. Springer, New York City (in press).

Belzile, N., Chena, Y.-W., Gunn, J.M., Dixit, S.S., 2004. Sediment trace metal profiles in lakes of Killarney Park, Canada: from regional to continental influence. Environ. Pollut. 130, 239-248.

Blomqvist, S., Gunnars, A., Elmgren, R., 2004. Why the limiting nutrient differs between temperate coastal seas and freshwater lakes: A matter of salt. Limnol. Oceanogr. 49, 2236-2241.

Brix, K.V., DeForest, D.K., Cardwell, R.D., Adams, W.J., 2004. Derivation of a chronic site-specific water quality standard for selenium in the Great Salt Lake, Utah, USA. Environ. Toxicol. Chem. 23, 606612.

Bunting, L., Leavitt, P.R., Simpson, G.L., Wissel, B., Laird, K.R., Cumming, B.F., St. Amand, A., Engstrom, D.R., 2016. Increased variability and sudden ecosystem state change in Lake Winnipeg, Canada, caused by 20th century agriculture. Limnol. Oceanogr. 61, 2090-2107.

Chaillou, G., Schäfer, J., Anschutz, P., Lavaux, G., Blanc, G., 2003. The behaviour of arsenic in muddy sediments of the Bay of Biscay (France). Geochim. Cosmochim. Acta 67, 2993-3003.

Child, A.W., Moore, B.C., Vervoort, J.D., Beutel, M.W., 2018. Tracking long-distance atmospheric deposition of trace metal emissions from smelters in the upper Columbia River valley using $\mathrm{Pb}$ isotope analysis of lake sediments. Environ. Sci. Pollut. Res. 25, 5501-5513.

Conover, M.R., Vest, J.L., 2009. Concentrations of selenium and mercury in eared grebes (Podiceps nigricollis) from Utah's Great Salt Lake, USA. Environ. Toxicol. Chem. 28, 1319-1323.

Couillard, Y., Cattaneo, A., Gallon, C., Courcelles, M., 2008. Sources and chronology of fifteen elements in the sediments of lakes affected by metal deposition in a mining area. J. Paleolimnol. 40, 97114.

Diaz, X., Johnson, W.P., Naftz, D.L., 2009a. Selenium mass balance in the Great Salt Lake, Utah. Sci. Total Environ. 407, 2333-2341.

Diaz, X., Johnson, W.P., Oliver, W.A., Naftz, D.L., 2009b. Volatile selenium flux from the Great Salt Lake, Utah. Environ. Sci. Technol. 43, 53-59.

Domagalski, J.L., Eugster, H.P., 1990. Trace metal geochemistry of Walker, Mono, and Great Salt Lakes, in: Spencer, R.J., Chou, I. (Eds.), Fluid-Mineral Interactions: A Tribute to H.P. Eugster. The Geochemical Society, pp. 315-353.

Ege, C.L., 2005. Selected mining districts of Utah. Miscellaneous Publication 05-5. Utah Geological Survey, Salt Lake City, Department of Natural Resources, Salt Lake City.

Ek, A.S., Renberg, I., 2001. Heavy metal pollution and lake acidity changes caused by one thousand years of copper mining at Falun, central Sweden. J. Paleolimnol. 26, 89-107.

Ellis, M.T., 1986. Acid deposition in Utah: An analysis by the acid deposition Technical Advisory Committee, in: Quality, U.B.o.A. (Ed.). Bureau of Air Quality. https://www.google.com/url?sa=t\&rct=j\&q=\&esrc=s\&source=web\&cd=2\&ved=2ahUKEwjXreTSh d oAhXHU80KHVc6AekQFjABegQIAxAB\&url=http\%3A\%2F\%2Fdigitallibrary.utah.gov\%2Fawweb \%2Fawarchive\%3Ftype\%3Dfile\%26item\%3D55765\&usg=AOvVaw0RmydNDv7sK4bKqBk5aarz (accessed 10 Apr 2020), Salt Lake City, p. 113.

Engstrom, D.R., Wright, J.H.E., 1984. Chemical stratigraphy of lake sediments as a record of environmental change, in: Haworth, E.Y., Lund, J.W.G. (Eds.), Lake sediments and environmental history. University of Leicester Press, Leicester, pp. 11-67. 
EPA, 1996. Acid digestion of sludges, solids and soils; USEPA 3050B, In SW-846 Pt 1; Office. 404 of Solid and Hazardous Wastes, U.S. Environmental Protection Agency, Cincinnati, $\mathrm{OH}$. https://www.epa.gov/esam/epa-method-3050b-acid-digestion-sediments-sludges-and-soils.

EPA, 2002. EPA Superfund record of decision: Kennecott (North Zone and South Zone). U.S. Environmental Protection Agency, Region 8. 265 p. Denver. https://digitalcommons.usu.edu/govdocs/488/ (accessed 10 Apr 2020), Denver, Colorado.

EPA, 2003. Administrative order on consent for removal action, Northwest Oil Drain Superfund Site, Salt Lake City, UT. Federal Register. https://www.federalregister.gov/documents/2003/11/07/0328105/administrative-order-on-consent-for-removal-action-northwest-oil-drain-superfund-sitesalt-lake-city (accessed 9 Apr 2020).

Erdinger, L., Eckl, P., Ingel, F., Khussainova, S., Utegenova, E., Mann, V., Gabrio, T., 2004. The Aral Sea disaster - human biomonitoring of $\mathrm{Hg}, \mathrm{As}, \mathrm{HCB}, \mathrm{DDE}$, and PCBs in children living in Aralsk and Akchi, Kazakhstan. Int. J. Hyg. Environ. Health 207, 541-547.

Gawel, J.E., Asplund, J.A., Burdick, S., Miller, M., Peterson, S.M., Tollefson, A., Ziegler, K., 2014. Arsenic and lead distribution and mobility in lake sediments in the south-central Puget Sound watershed: The long-term impact of a metal smelter in Ruston, Washington, USA. Sci. Total Environ. 472, 530-537.

Glew, J.R., Smol, J.P., Last, W.M., 2001. Sediment core collection and extrustion, in: Last, W.M., Smol, J.P. (Eds.), Tracking environmental change using lake sediments volume 1: Basin analysis, coring, and chronological techniques. Kluwer, pp. 73-106.

Goudie, A.S., 2014. Desert dust and human health disorders. Environ. Int. 63, 101-113.

Haas, M., Baumann, F., Castella, D., Haghipour, N., Reusch, A., Strasser, M., Eglinton, T.I., Dubois, N., 2019. Roman-driven cultural eutrophication of Lake Murten, Switzerland. Earth Planet. Sci. Lett. 505, 110-117.

Hamilton-Taylor, J., Davison, W., 1995. Redox-driven cycling of trace elements in lakes, in: Lerman, A., D. , Imboden, D., Gat, J. (Eds.), Physics and chemistry of lakes. Springer-Verlag, Berlin, p. 334.

Hamilton, S.J., Buhl, K.J., 2005. Selenium in the Blackfoot, Salt, and Bear River watersheds. Environ. Monit. Assess. 104, 309-339.

Hokanson, L., 1980. Ecological risk index for aquatic pollution control, a sedimentological approach. Water Res. 14, 975-1001.

Hughes, C.E., 1990. The development of the smelting industry in the Central Salt Lake Valley communities of Midvale, Murray, and Sandy Prior to 1900. Ph.D. thesis, Brigham Young University. https://scholarsarchive.byu.edu/etd/4810 (accessed 10 Apr 2020), History, Provo, Utah.

Jamieson, H.E., 2014. The legacy of arsenic contamination from mining and processing refractory gold ore at Giant Mine, Yellowknife, Northwest Territories, Canada. Rev. Mineral. Geochem. 79, 533551.

Javor, B., 1989. Hypersaline environments: Microbiology and biogeochemistry. Springer-Verlag, Berlin. Jin, Z., Li, X., Zhang, B., Han, Y., Zheng, G., 2013. Geochemical records in Holocene lake sediments of northern China: Implication for natural and anthropogenic inputs. Quat. Int. 304, 200-208.

Johnson, W.P., Wurtsbaugh, W.A., Belovsky, G.E., Baxter, B.K., Black, F., Angeroth, C., Jewell, P., Yang, S., 2019. Geochemistry of Great Salt Lake, in: Maurice, P. (Ed.), Encyclopedia of Water. Wiley, pp. 116.

Jones, B.F., Naftz, D.L., Spencer, R.J., Oviatt, C.G., 2009. Geochemical evolution of Great Salt Lake, Utah, USA. Aquat. Geochem. 15, 95-121.

Jones, E.F., Wurtsbaugh, W.A., 2014. The Great Salt Lake's monimolimnion and its importance for mercury bioaccumulation in brine shrimp (Artemia franciscana). Limnol. Oceanogr. 59, 141-155. 
Kada, J., Heit, M., Miller, K.M., 1994. Chronology of anthropogenic trace-element input to four Utah lakes reconstructed using sediment cores. Water Air Soil Pollut. 75, 353-369.

Laws, E.A., 1993. Aquatic pollution: An introductory text. John Wiley and Sons, New York.

Leppänen, J.J., Weckström, J., Korhola, A., 2017. Multiple mining impacts induce widespread changes in ecosystem dynamics in a boreal lake. Sci. Rep. 7, 10581.

MacDonald, D.D., Ingersoll, C.G., Berger, T.A., 2000. Development and evaluation of consensus-based sediment quality guidelines for freshwater ecosystems. Arch. Environ. Contam. Toxicol. 39, 2031.

Mars, J.C., Crowley, J.K., 2003. Mapping mine wastes and analyzing areas affected by selenium-rich water runoff in southeast Idaho using AVIRIS imagery and digital elevation data. Remote Sens. Environ. 84, 422-436.

Maszczyk, P., Wurtsbaugh, W.A., 2017. Brine shrimp grazing and fecal production increase sedimentation to the deep brine layer (monimolimnion) of Great Salt Lake, Utah. Hydrobiologia $802,7-22$.

McPhee, W.M., 1977. The trail of the leprechaun. Exposition Press, Hicksville.

Miller, L.G., Jellison, R., Oremland, R.S., Culbertson, C.W., 1993. Meromixis in hypersaline Mono Lake, California. 3. Biogeochmical response to stratification and overturn. Limnol. Oceanogr. 38, 1040-1051.

Moore, J.N., Luoma, S.N., Peters, D., 1991. Downstream effects of mine effluent on an intermontane riparian system. Can. J. Fish. Aquat. Sci. 48, 222-232.

Moser, K.A., Mordecai, J.S., Reynolds, R.L., Rosenbaum, J.G., Ketterer, M.E., 2010. Diatom changes in two Uinta mountain lakes, Utah, USA: responses to anthropogenic and natural atmospheric inputs. Hydrobiologia 648, 91-108.

Naftz, D., C. Angeroth, T. Kenney, B. Waddell, N. Darnall, S. Silva, C. Perschon, and J. Whitehead, 2008. Anthropogenic influences on the input and biogeochemical cycling of nutrients and mercury in Great Salt Lake, Utah, USA. Appl. Geochem. 23, 1731-1744.

Naftz, D., Johnson, W.P., Freeman, M.L., Beisner, K., Diaz, X., Cross, V.A., 2009. Estimation of selenium loads entering the south arm of the Great Salt Lake, Utah, from May 2006 through March 2008. U.S. Geological Survey. https://pubs.usgs.gov/sir/2008/5069/ (Accessed 10 Apr 2020), Reston, Virginia, p. 40.

Naftz, D.L., Stephens, D.W., Callender, E., Van Metre, P.C., 2000. Reconstructing historical changes in the environmental health of watersheds by using sediment cores from lakes and reservoirs in Salt Lake Valley, Utah, U.S. Geological Survey. Fact Sheet FS-164-00, Salt Lake City, UT, p. 6.

Newman, C.J., Collins, D.N., Weddick, A.J., 1999. Recent operation and environmental control in the Kennecott Smelter, in: Diaz, C., Landolt, C., Utigard, T. (Eds.), Copper 99-Cobre 99: Smelting Technology Development, Process Modeling and Fundamentals. Minerals, Metals, and Materials Society, Warrendale, PA., pp. 29-45.

Nriagu, J.O., Wong, H.K.T., Coker, R.D., 1982. Deposition and chemistry of pollutant metals in lakes around the smelters at Sudbury, Ontario. Environ. Sci. Technol. 16, 551-560.

Oliver, W., Fuller, C., Naftz, D.L., Johnson, W.P., Diaz, X., 2009. Estimating selenium removal by sedimentation from the Great Salt Lake, Utah. Appl. Geochem. 24, 936-949.

Peterson, C., Gustin, M., 2008. Mercury in the air, water and biota at the Great Salt Lake (Utah, USA). Sci. Total Environ. 405, 255-268.

Plumlee, G.S., Montour, M., Taylor, C.D., Wallace, A.R., Klein, D.P., 1996. Chapter 14. Polymetallic vein and replacement deposits, in: du Bray, E.A. (Ed.), Preliminary compilation of descriptive geoenvironmental mineral deposit models. U.S. Geological Survey, Denver.

Reynolds, C.S., 2006. Phytoplankton ecology. Cambridge University Press, Cambridge. 
Reynolds, R.L., Mordecai, J.S., Rosenbaum, J.G., Ketterer, M.E., Walsh, M.K., Moser, K.A., 2010. Compositional changes in sediments of subalpine lakes, Uinta Mountains (Utah): evidence for the effects of human activity on atmospheric dust inputs. J. Paleolimnol. 44, 161-175.

Rickard, D., Luther, G.W., 2007. Chemistry of iron sulfides. Chemical Reviews 107, 514-562.

Roberts, A.J., 2013. Avian diets in a saline ecosystem: Great Salt Lake, Utah, USA. Hum-Wildl. Interact. 7, 149-159.

Schelske, C.L., Peplow, A., Brenner, M., Spencer, C.N., 1994. Low-background gamma counting: Applications for ${ }^{210} \mathrm{~Pb}$ dating of sediments J. Paleolimnol. 10, 115-128.

Schuh, C.E., Jamieson, H.E., Palmer, M.J., Martin, A.J., Blais, J.M., 2019. Controls governing the spatial distribution of sediment arsenic concentrations and solid-phase speciation in a lake impacted by legacy mining pollution. Sci. Total Environ. 654, 563-575.

Smrzka, D., Zwicker, J., Bach, W., Feng, D., Himmler, T., Chen, D., Peckmann, J., 2019. The behavior of trace elements in seawater, sedimentary pore water, and their incorporation into carbonate minerals: a review. Facies 65, 41.

Sorensen, D.L., others, 1988. Great Salt Lake inter-island diking: water quality considerations. Utah Water Research Laboratory, Logan, Utah. https://digitalcommons.usu.edu/water rep/597, Logan, Utah. https://digitalcommons.usu.edu/water rep/597.

Sturm, P.A., 1980. The Great Salt Lake brine system, in: Gwynn, J.W. (Ed.), Great Salt Lake: a scientific,historical and economic overview. Utah Department of Natural Resources, Salt Lake City, UT, pp. 147-162.

Suedel, B.C., Boraczek, J.A., Peddicord, R.K., Clifford, P.A., Dillon, T.M., 1994. Trophic transfer and biomagnification potential of contaminants in aquatic ecosystems, in: Ware, G.W. (Ed.), Reviews of Environmental Contamination and Toxicology. Springer New York, New York, NY, pp. 21-89.

Thienpont, J.R., Korosi, J.B., Hargan, K.E., Williams, T., Eickmeyer, D.C., Kimpe, L.E., Palmer, M.J., Smol, J.P., Blais, J.M., 2016. Multi-trophic level response to extreme metal contamination from gold mining in a subarctic lake. Proc. R. Soc. Lond., Ser. B: Biol. Sci. 283, 20161125.

Tiffany, M.A., González, M.R., Swan, B.K., Reifel, K.M., Watts, J.M., Hurlbert, S.H., 2007. Phytoplankton dynamics in the Salton Sea, California, 1997-1999. Lake Reserv. Manage. 23, 582-605.

Utah Department of Environmental Quality, 2019. Utah waterfowl advisories. https://deq.utah.gov/water-quality/utah-waterfowl-advisories (Accessed $10 \mathrm{Apr}$ 2020).

Utah Geological Survey, 2011. Chapter 9: Industrial minerals and metals. Utah Department of Natural Resources. http://geology.utah.gov/emp/energydata/mineralsdata.htm (Accessed $10 \mathrm{Apr}$ 2020), Salt Lake City, p. Metals production data.

Varley, T., Stevenson, C.C., Reid, W.S., 1921. Utah's Mineral Wealth. Commercial Club, Salt Lake City. https://books.google.com/books?id=kzROAAAAYAAJ\&pg=PA1\&lpg=PA1\&dq=Varley+\%22Utah\% 27s+mineral+wealth,+represented+by+statistics+and+graphic+charts+compiled+from+official+g overnment+and+state+reports\%22\&source=bl\&ots=c6iuznrGqH\&sig=ACfU3U13RYMoqJXXA7Aj3 wWbf9q70UKr3w\&hl=en\&sa=X\&ved=2ahUKEwi75Ock9 oAhVBBc0KHWYxDtkQ6AEwAHoECAMQKQ\#v=onepage\&q=Varley\%20\%22Utah's\%20mine ral\%20wealth\%2C\%20represented\%20by\%20statistics\%20and\%20graphic\%20charts\%20compile d\%20from\%20official\%20government\%20and\%20state\%20reports\%22\&f=false (Accessed 10 Apr 2020), Salt Lake City.

Waddell, B., Cline, C., Darnall, N., Boeke, E., Sohn, R., 2009. Assessment of contaminants in the wetlands and open waters of the Great Salt Lake, Utah 1996-2000. U.S. Fish and Wildlife Service Report R6/C-01-U/0, Salt Lake City. https://www.fws.gov/utahfieldoffice/Documents/Contaminants/Contaminants Wetlands Open Waters Great Salt Lake.pdf. 
Washington Department of Ecology, 2013. Sediment Management Standards, Chapter 173-204 WAC, Publication no. 13-09-055, https://fortress.wa.gov/ecy/publications/SummaryPages/1309055.html (Accessed $10 \mathrm{Apr} 2020$ ). Wurtsbaugh, W.A., 1992. Food web modifications by an invertebrate predator in the Great Salt Lake (USA). Oecologia 89, 168-175.

Wurtsbaugh, W.A., 2012. Paleolimnological analysis of the history of metals contamination in the Great Salt Lake, Utah, USA. Final report to the Utah Division of Water Quality, Salt Lake City, Utah. 44 p. http://digitalcommons.usu.edu/wats facpub/556/.

Wurtsbaugh, W.A., Gardberg, J., Izdepski, C., 2011. Biostrome communities and mercury and selenium bioaccumulation in the Great Salt Lake (Utah, USA). Sci. Total Environ. 409, 4425-4434.

Wurtsbaugh, W.A., Marcarelli, A.M., 2006. Eutrophication in Farmington Bay, Great Salt Lake, Utah. Report to the Central Davis Sewer Improvement District, Kaysville, UT. Utah State University. https://digitalcommons.usu.edu/wats facpub/560/ (Accessed 10 Apr 2020), Logan, Utah, p. 91.

Wurtsbaugh, W.A., Marcarelli, A.M., Boyer, G.L., 2012. Eutrophication and metal concentrations in three bays of the Great Salt Lake (USA). Final report to the Utah Division of Water Quality, Salt Lake City, Utah. 70 p. http://digitalcommons.usu.edu/cgi/viewcontent.cgi?article=1548\&context=wats facpub. Accessed 10 Apr 2020.

Wurtsbaugh, W.A., Miller, C., Null, S.E., DeRose, R.J., Wilcock, P., Hahnenberger, M., Howe, F., Moore, J., 2017. Decline of the world's saline lakes. Nat. Geosci. 10, 816-821 (810.1038/ngeo3052).

Yang, S., Johnson, W.P., Black, F.J., Rowland, R., Rumsey, C., Piskadlo, A., 2019. Response of density stratification, aquatic chemistry, and methylmercury to engineered and hydrologic forcings in an endorheic lake (Great Salt Lake, U.S.A.). Limnol. Oceanogr. https://doi.org/10.1002/Ino.11358. 


\section{Figure captions}

683 Fig. 1. Map of the Great Salt Lake showing the coring sites, causeways, and the locations of the 684 Bingham Canyon porphyry copper mine (Kennecott Mines) and smelters.

685 Fig. 2. Left frames: Concentrations of $\mathrm{Cu}, \mathrm{Hg}, \mathrm{Pb}$ and $\mathrm{Zn}$ in sediments of different ages from the 686 two coring sites in Gilbert Bay. Concentrations are salt-corrected. Dotted vertical lines show 687 Threshold Effects Concentrations (TEC; ---) and Probable Effects Concentrations (PEC; -“-) of 688 sediments in freshwater ecosystems. Right frames: Metal production in Utah derived from Utah 689 Geological Survey (2011) Utah Geological Survey . Note that although zinc was mined along 690 with lead, it was not valued as a commodity until the early 1900s (K. Krahulec, Utah Geological 691 Survey, personal communication).

692 Fig. 3. Concentrations of selenium (left) and arsenic (right) from two sediment cores in Gilbert 693 Bay of the Great Salt Lake.

694 Fig. 4. Maximum Enrichment Factor (maximum/background) in the sediment core from Gilbert

695 Bay (Site 4) (blue) and the Current Enrichment Factors (surface concentration/background; red) 696 for 11 metals and semi-metals. These values are based on the actual maxima (not the 3-pt running 697 means) that are shown in Figure 5. The down-arrow depicts how concentrations of many metals 698 in Gilbert Bay are now considerably lower than during the highest contamination period in the 6991950 s and 1960s.

700 Fig. 5. Mean surface $(0-1 \mathrm{~cm})$ concentrations of copper $(\mathrm{Cu})$, mercury $(\mathrm{Hg})$, cadmium $(\mathrm{Cd})$ and 701 lead $(\mathrm{Pb})$ at eight sites in the Great Salt Lake expressed as a percentage of the Probable Effects 702 Concentrations (PEC) developed for freshwater organisms (Table 1; MacDonald et al. 2000). 


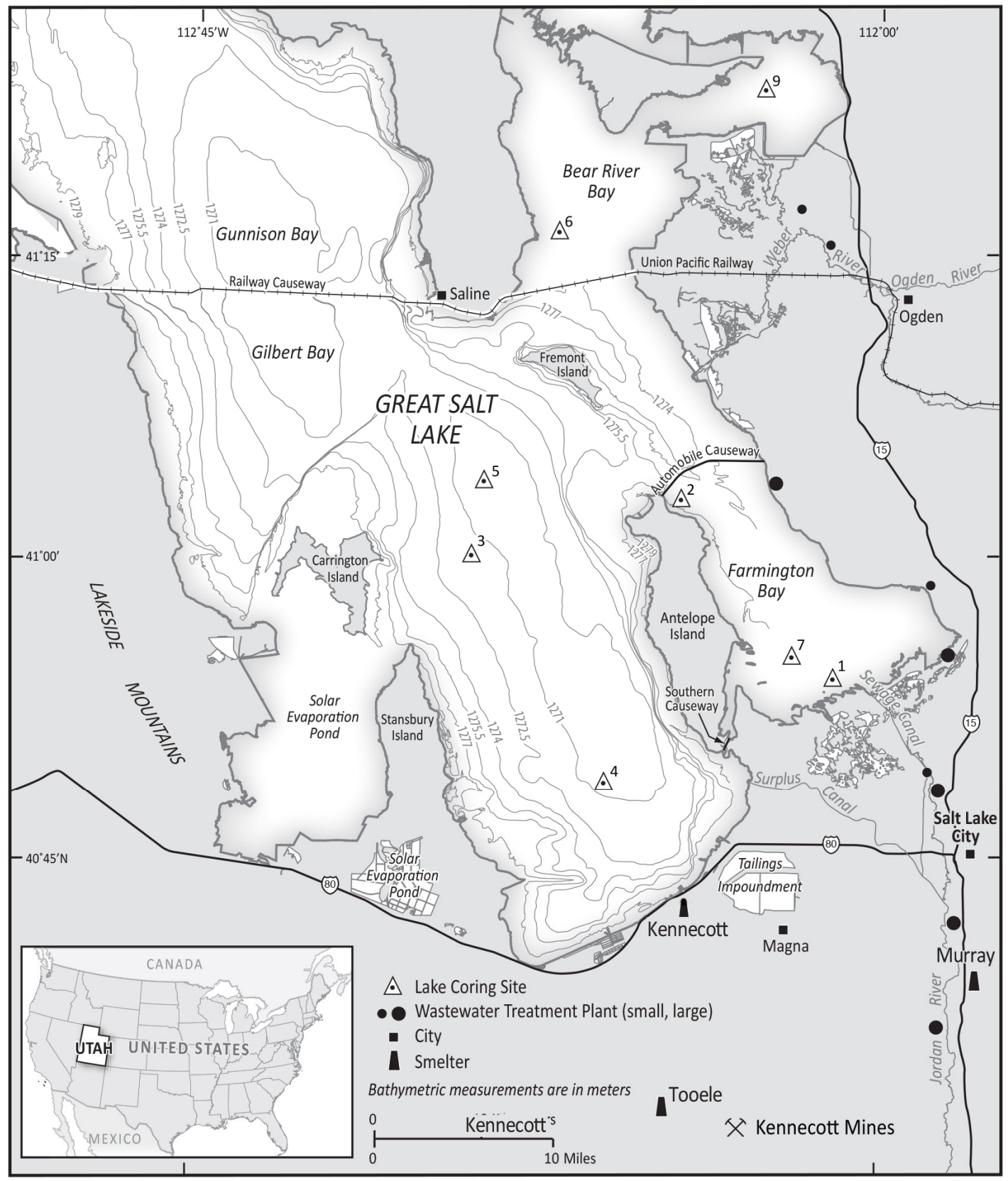

Fig. 1. Map of the Great Salt Lake showing the coring sites, causeways, and the locations of the Bingham Canyon porphyry copper mine (Kennecott Mines) and smelters. 

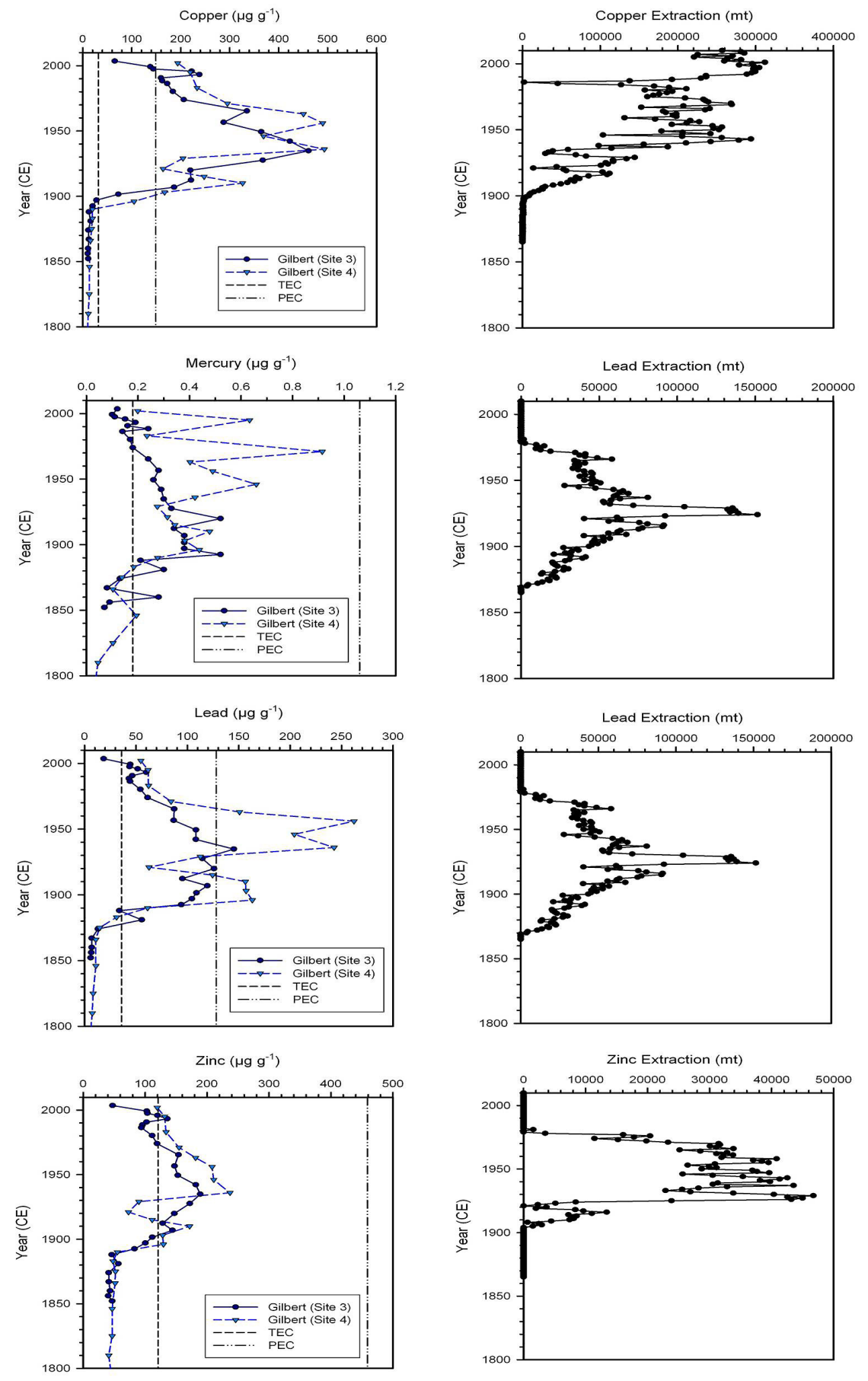

Fig. 2. Left frames: Concentrations of $\mathrm{Cu}, \mathrm{Hg}, \mathrm{Pb}$ and $\mathrm{Zn}$ in sediments of different ages from the two coring sites in Gilbert Bay. Concentrations are salt-corrected. Dotted vertical lines show Threshold Effects Concentrations (TEC; ---) and Probable Effects Concentrations (PEC; ---) of sediments in fresh water ecosystems. Right frames: Metal production in Utah derived from Utah Geological Survey 2011. Note that although zinc was mined along with lead, it was not valued as a commodity until the early 1900s (K. Krahulec personal communication). 

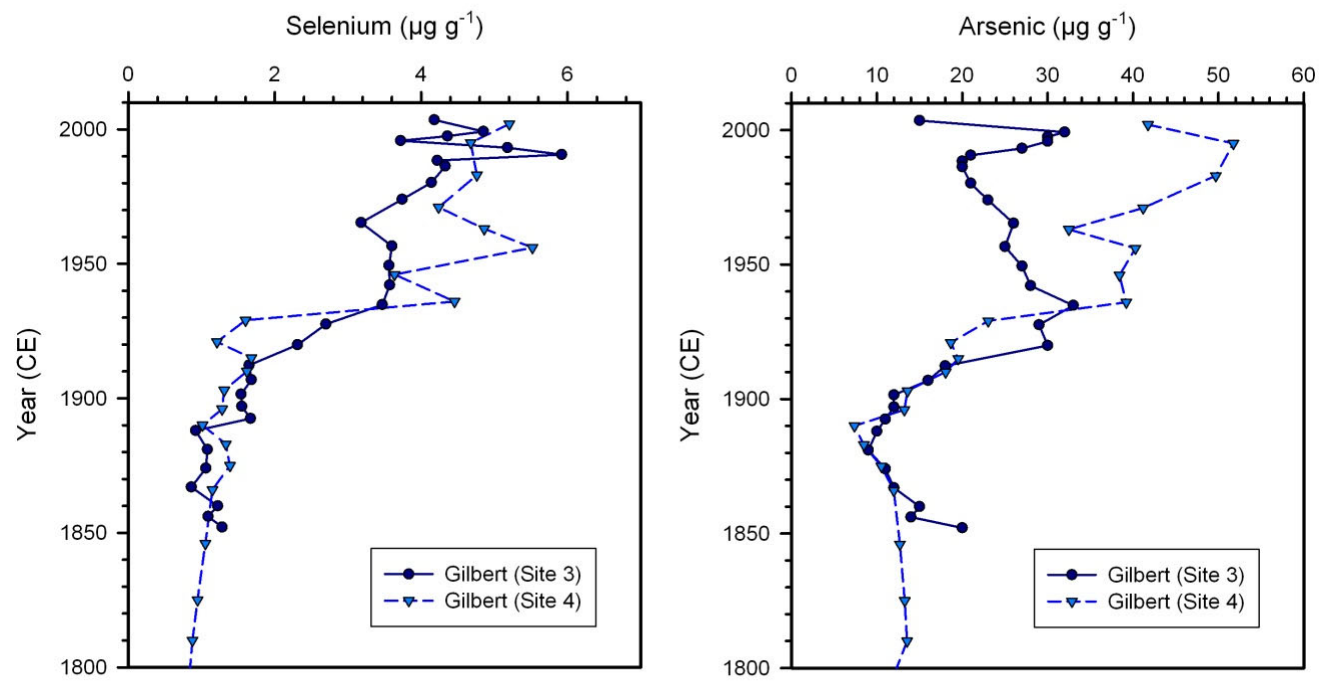

Fig. 3. Concentrations of selenium (left) and arsenic (right) from two sediment cores in Gilbert Bay of the Great Salt Lake. 


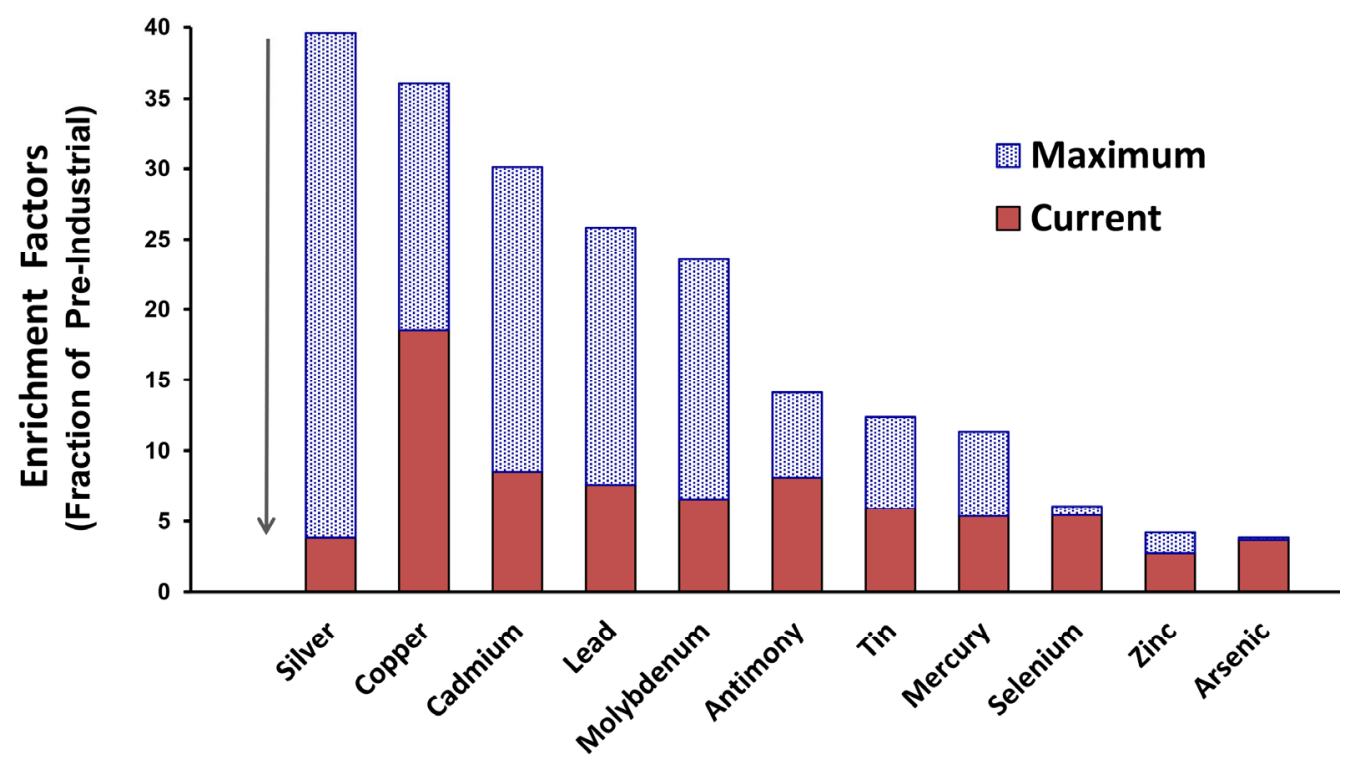

Fig. 4. Maximum Enrichment Factor (maximum/background) in the sediment core from Gilbert Bay (Site 4) (blue) and the Current Enrichment Factors (surface concentration/background; red) for 11 metals and semi-metals. These values are based on the actual maxima (not the 3-pt running means) that are shown in Figure 5. The down-arrow depicts how concentrations of many metals in Gilbert Bay are now considerably lower than during the highest contamination period in the 1950s and 1960s. 


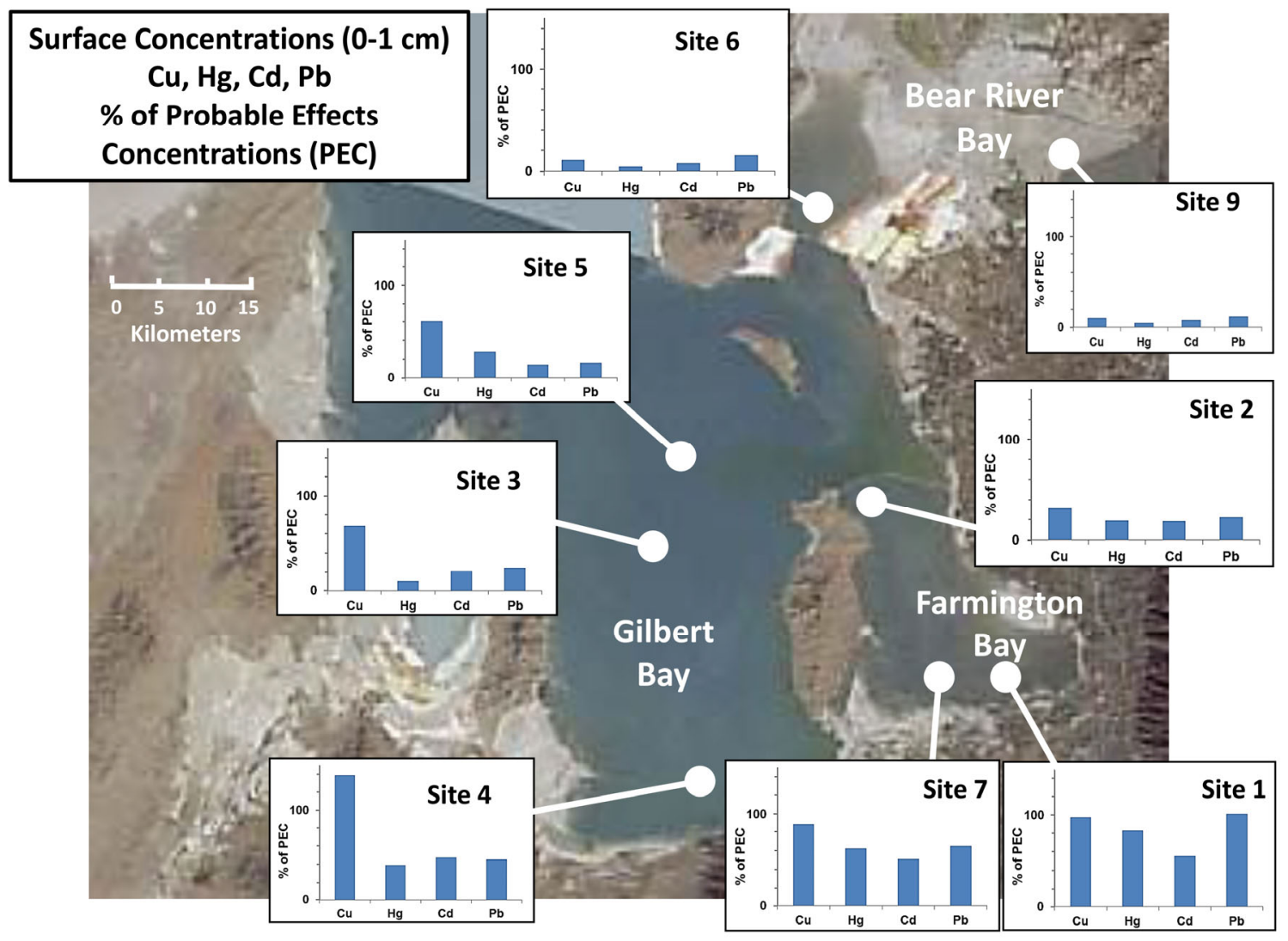

Fig. 5. Mean surface $(0-1 \mathrm{~cm})$ concentrations of copper $(\mathrm{Cu})$, mercury $(\mathrm{Hg})$, cadmium $(\mathrm{Cd})$ and lead $(\mathrm{Pb})$ at eight sites in the Great Salt Lake expressed as a percentage of the Probable Effects Concentrations (PEC) developed for freshwater organisms (Table 1; MacDonald et al. 2000). 


\section{Appendix A. Supplementary data}

Table S1. Sediment sampling sites and characteristics. Sites 3 and 4 in Gilbert Bay were used

712 for historical reconstruction of metal deposition, whereas other sites were used to assess spatial

713 distribution of surficial sediments. Salinities just above the bottom are given because this is the

714 layer influencing metals in the sediments.

\begin{tabular}{|c|c|c|c|c|c|c|c|c|}
\hline \multirow[b]{3}{*}{ Site Characteristics } & \multicolumn{8}{|c|}{ Bay and Site Number } \\
\hline & \multicolumn{3}{|c|}{ Gilbert Bay } & \multicolumn{3}{|c|}{ Farmington Bay } & \multicolumn{2}{|c|}{ Bear River Bay } \\
\hline & 3 & 4 & 5 & 1 & 2 & 7 & 6 & 9 \\
\hline \multirow[t]{2}{*}{ Coordinates } & $41.0090 \mathrm{~N}$ & $40.8251 \mathrm{~N}$ & $41.0720 \mathrm{~N}$ & $40.9142 \mathrm{~N}$ & $41.0584 \mathrm{~N}$ & $40.9318 \mathrm{~N}$ & $41.2766 \mathrm{~N}$ & $41.3933 \mathrm{~N}$ \\
\hline & -112.4996 W & $-112.2971 \mathrm{~W}$ & $-112.4284 \mathrm{~W}$ & $-112.0500 \mathrm{~W}$ & $-112.2172 \mathrm{~W}$ & $-112.0956 \mathrm{~W}$ & $-112.3519 \mathrm{~W}$ & $-112.1280 \mathrm{~W}$ \\
\hline Collection Date & 18-Aug-09 & 19-Aug-09 & 20-Aug-09 & 17-Aug-09 & 17-Aug-09 & 25-Jun-10 & 21-Aug-09 & 8-Jul-10 \\
\hline Station Depth $(\mathrm{m})$ & 7.35 & 7.80 & 7.94 & 0.15 & 1.01 & 0.68 & 0.12 & 0.70 \\
\hline Bottom Salinity $\left(\mathrm{g} \mathrm{L}^{-1}\right)$ & 172 & 175 & 199 & 1 & 80 & 4 & 145 & 2 \\
\hline Secchi Depth (m) & 0.7 & 3.8 & 2.2 & $>0.15$ & 0.16 & 0.38 & 0.5 (nearby site) & $>0.7$ \\
\hline
\end{tabular}




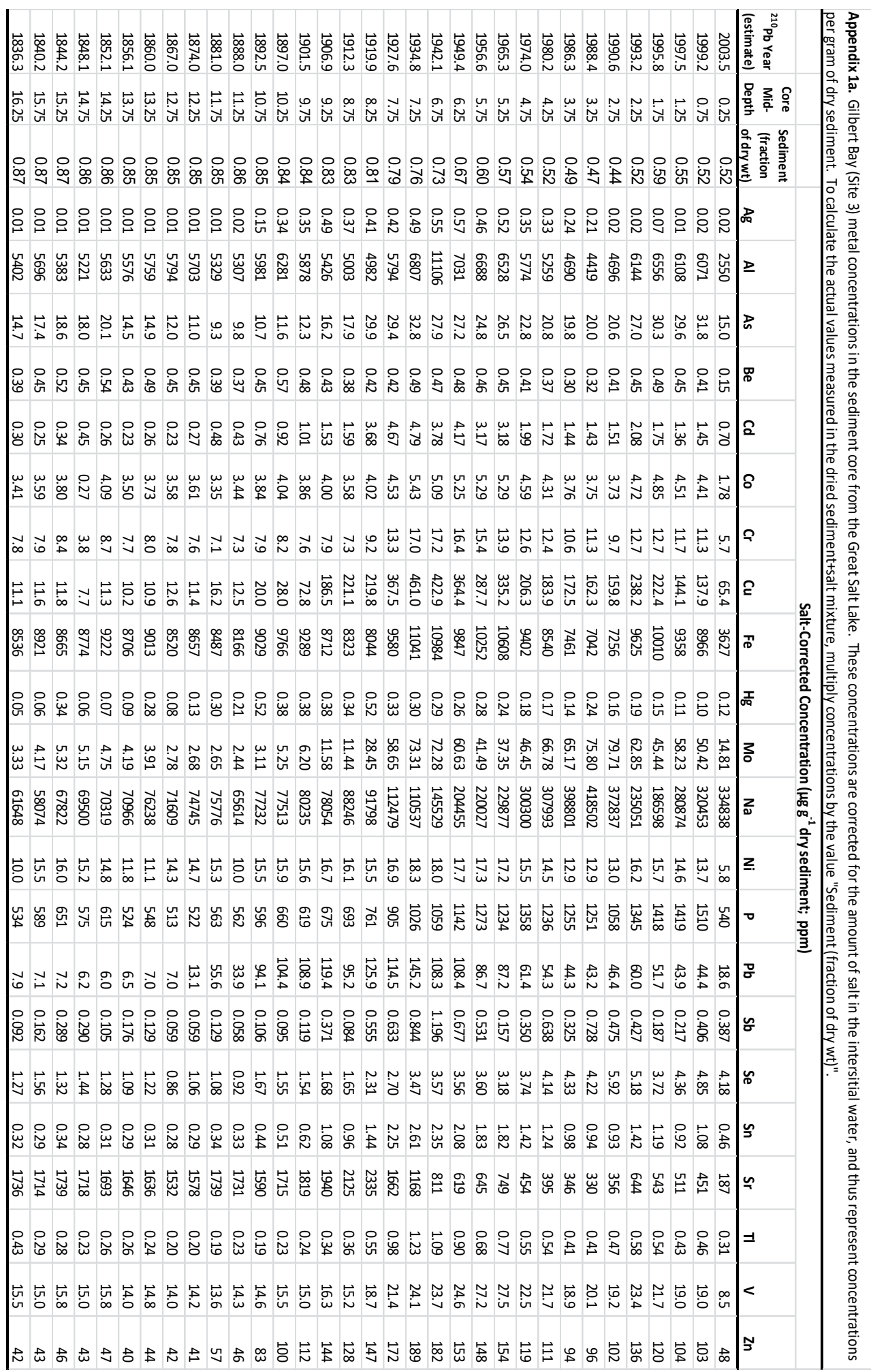




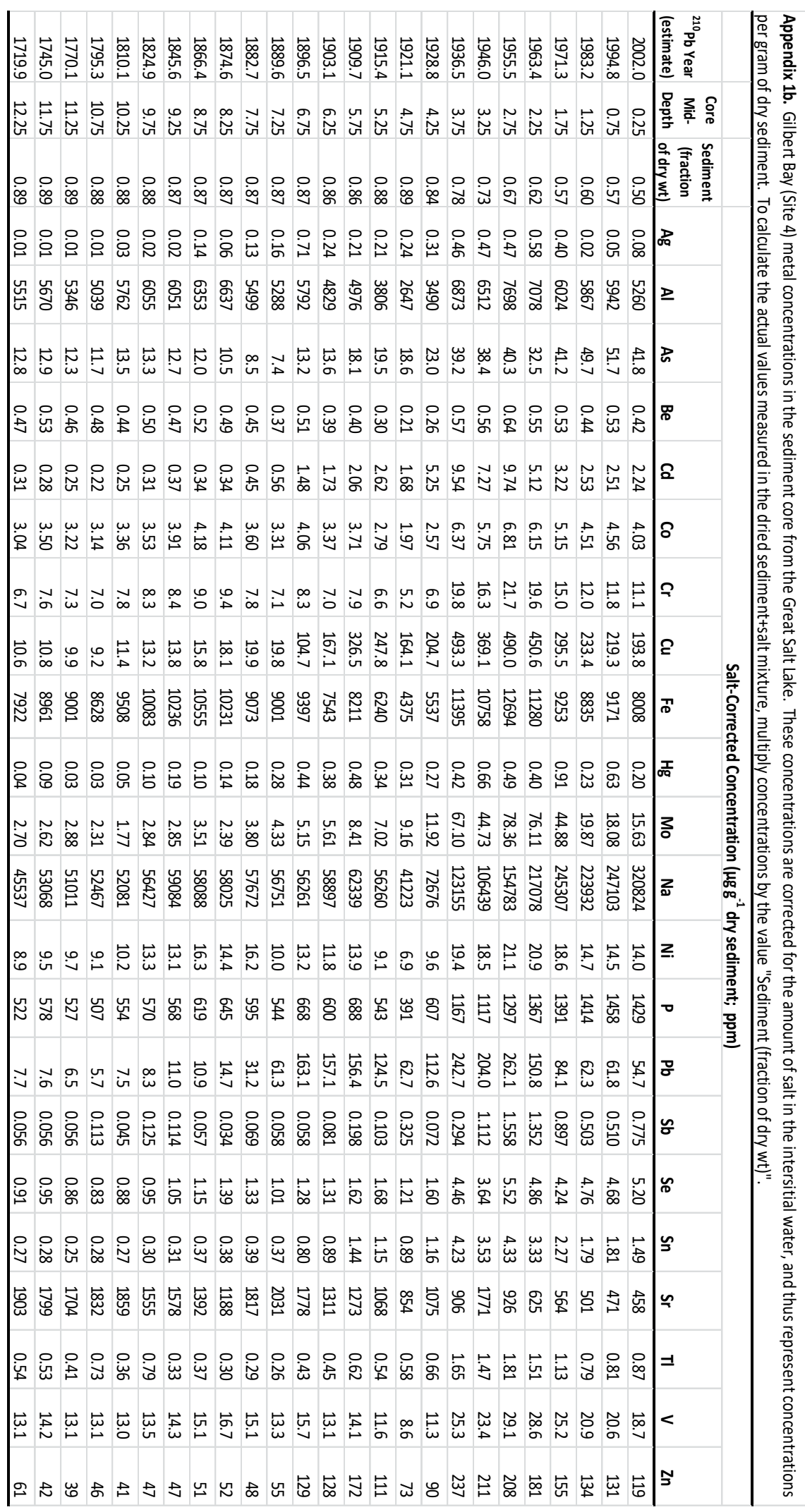



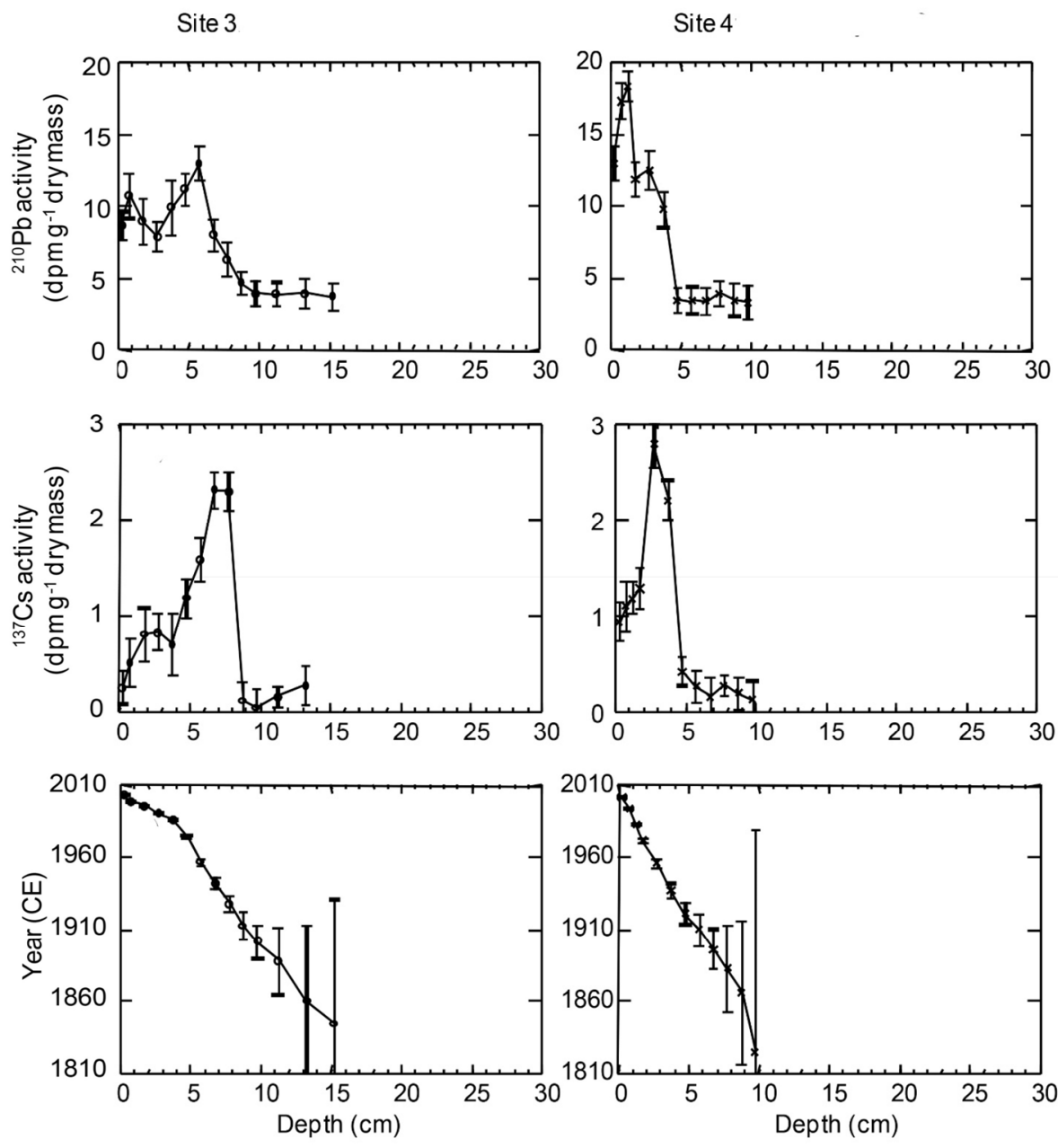

Fig. S1. Dating chronologies from Sites 3 and 4 in Gilbert Bay, Great Salt Lake, Utah. The top row shows activity of ${ }^{210} \mathrm{~Pb}$ (disintegrations per minute, dpm) uncorrected for background (supported) activity. The middle row shows ${ }^{137}$ cesium activity and the last row shows estimated dates and s.d. error bars based on variances in ${ }^{210} \mathrm{~Pb}$ counts. Estimates of radioisotope activity were performed on 12-14 samples per core at University of Regina following Bunting et al. (2016). 

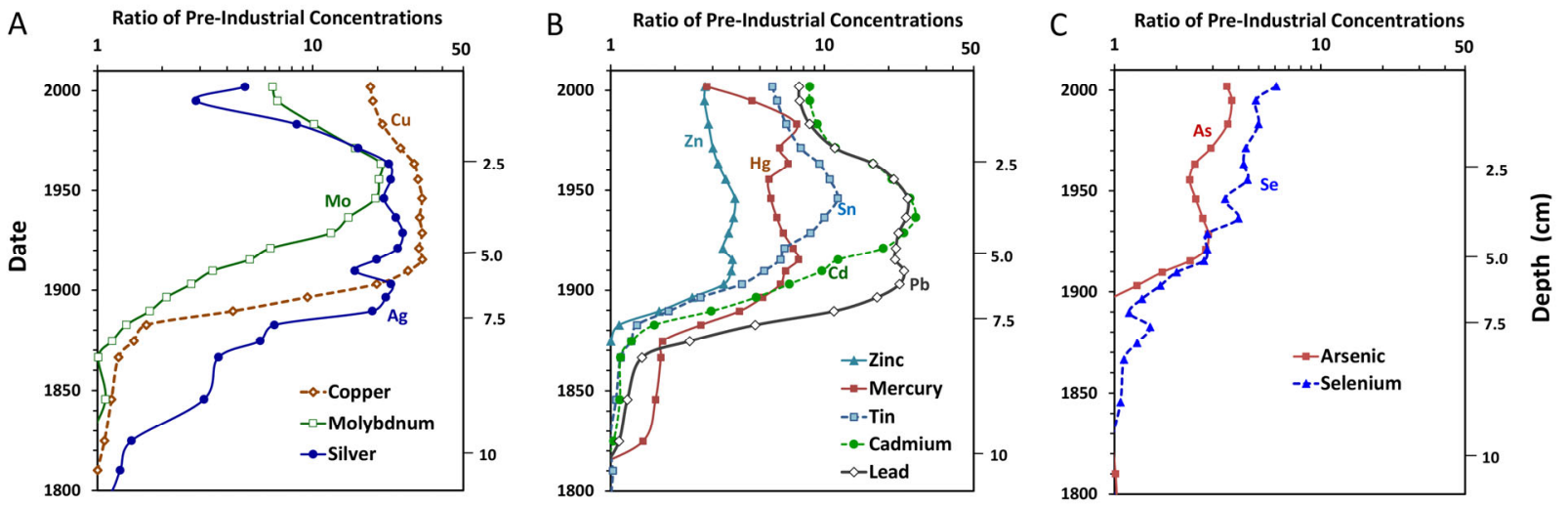

Fig. S2. Enrichment factors of metal concentrations at each depth in a Gilbert Bay core (Site 4) relative to mean concentrations prior to 1860. A ratio of 1 indicates background, uncontaminated conditions. Left. Metals derived primarily from porphyry copper and sedimentary rock-hosted gold and silver deposits in the Bingham Canyon and Mercur mining districts of Utah. Center. Ratio of metals derived from polymetallic replacement deposits in the Tintic, Park City and Bingham mining districts. Right. Ratios for arsenic and selenium that derive from the Bingham porphyry copper deposits (Se), and the sedimentary Mercur and Bingham district deposits (As). Three-point running means are plotted to smooth the curves. Note log scales. Data for Site 3 were similar, but the Site 4 data is shown here because of its better ${ }^{210} \mathrm{~Pb} /{ }^{137} \mathrm{Cs}$ chronology. 


\section{Declaration of interests}

૫ The authors declare that they have no known competing financial interests or personal relationships that could have appeared to influence the work reported in this paper.

$\square$ The authors declare the following financial interests/personal relationships which may be considered as potential competing interests:

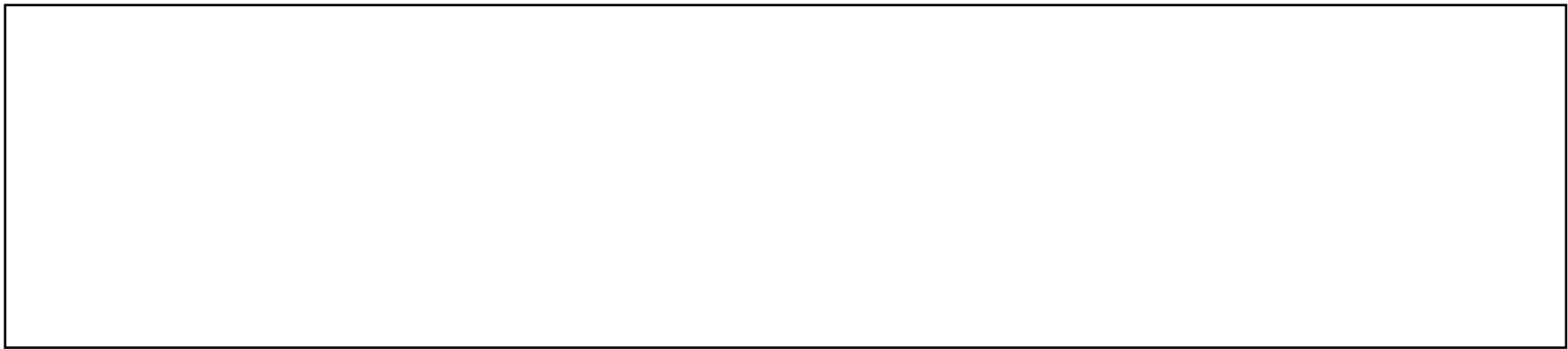




\title{
Paleolimnological Analysis of the History of Metals Contamination in the Great Salt Lake, Utah
}

\author{
Wayne A. Wurtsbaugh \\ Watershed Sciences Department and Ecology Center, Utah State University, \\ Logan, Utah, USA 84322-5210 \\ Final Report to the Utah Division of Water Quality \\ Salt Lake City
}

Submitted May 29, 2012

Resubmitted June 11, 2014

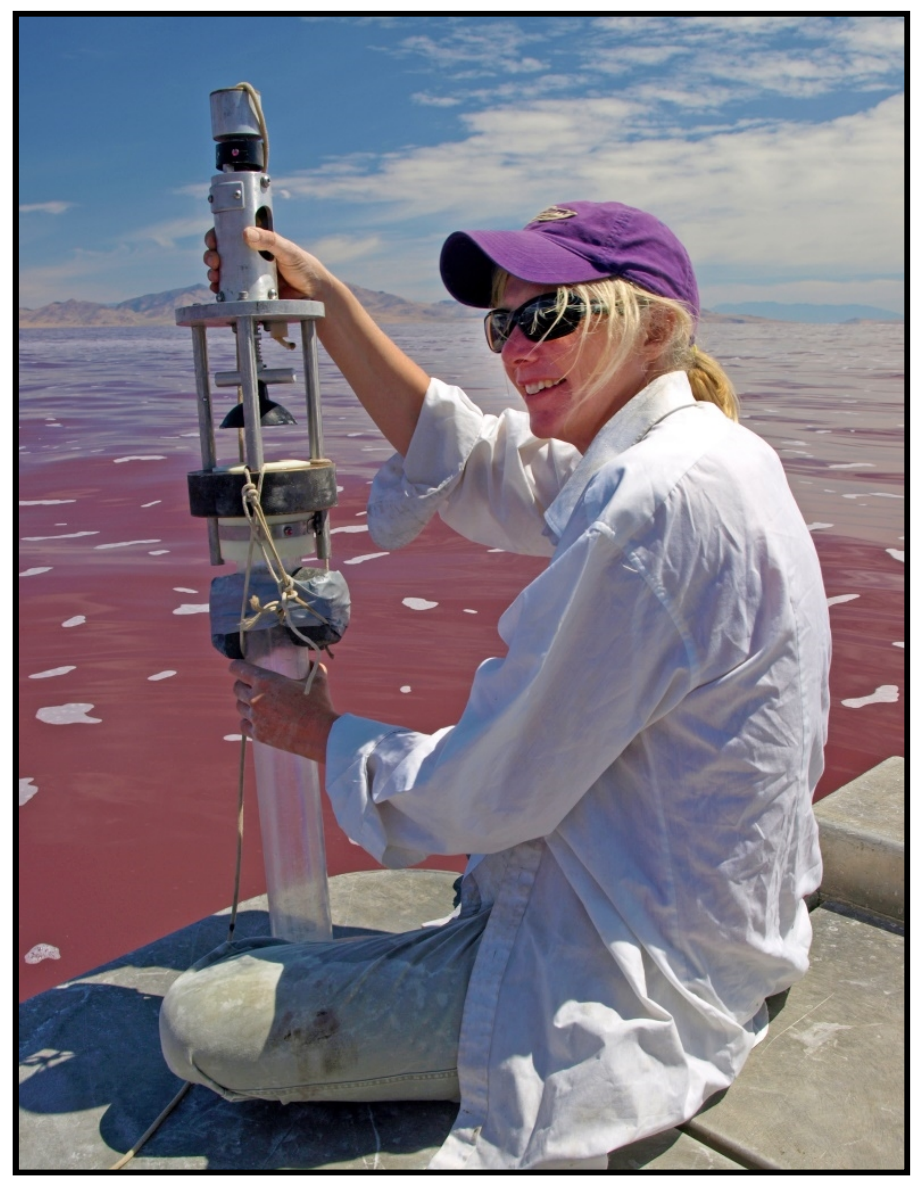

Dr. Katrina Moser Preparing the Glew Corer to Collect Sediment in the Great Salt Lake (Gunnison Bay) 


\begin{abstract}
Three sediment cores from the Great Salt Lake were analyzed to determine the magnitude and timing of the deposition of 21 metal contaminants. In the main lake (Gilbert Bay) concentrations of copper, lead, zinc, cadmium, silver, molybdenum, tin, mercury and others began increasing in the sediments in the late 1800 s or early 1900 s and peaked in the 1950s. These increases were coincident with increases in mining and smelting activities for these metals in Utah. Contamination indices in the 1950s were 20-60 fold above background concentrations for silver, copper, lead and molybdenum, and $<15$-fold for most other metals. Since the 1950s, concentrations of most metals in the sediments have decreased 2-5 fold, coincident with decreases in mining and improved smelting technologies. Nevertheless concentrations for many metals in surficial sediments are still above acceptable criteria established for freshwater ecosystems. In contrast to most metals, concentrations of selenium and arsenic were stable or increasing slightly in the Gilbert Bay sediments. In a coring site located in Farmington Bay near an EPA Superfund Site discharge canal, concentrations of metals were high and showed no indication of decreasing in more recent sediments, but this core only provided a 50-year record of contamination. Surficial sediments from additional sites in the Great Salt Lake indicated that metals were more concentrated towards the southern end of the lake where the primary sources of contamination were located.
\end{abstract}




\section{Introduction}

Mining and industrial activities frequently release toxic metals directly to waterways (Moore et al. 1991) or indirectly via atmospheric contamination (Nriagu 1979; Nriagu et al. 1982). The Great Salt Lake of Utah is located close to both major mining and smelting activities, and is also bordered by a large metropolitan area with extensive industrialization with wastewater releases into river tributaries. Beginning in the late 1800 s a variety of anthropogenic activities increased air and water pollution in the region (Lamborn and Peterson 1985). Mining for silver, lead and gold began in the region ca. 1863 (Varley et al. 1921; Mcphee 1977; Ege 2005) and the Bingham Canyon Mine, located in the Oquirrh Mountains (Fig. 1), opened in 1905. This mine was once the largest copper producer in the world, and over 16 million metric tons of copper have been produced from the open pit mine (Brix et al. 2006; Utah Geological Survey 2011b). Gold, silver and molybdenum have also been produced there in significant quantities as well as in other mines located in the Oquirrh Mountains, and in the Wasatch Range areas of Little Cottonwood Canyon and Park City. The smelter for the Bingham Canyon mine is currently located on the shore of the Great Salt Lake

(Fig. 2), but other smelters were located in the Salt Lake Valley, where ores from not only Utah, but much of the intermountain west were processed (Varley et al. 1921). The site of the former Murray smelter, located on the Jordan River 30 miles south of the Great Salt Lake, is now an EPA Superfund Site because of contamination of lead and arsenic that lasted from 1872 until 1949 (Keck and Lepori 2012). In addition to mining in the Oquirrh and Wasatch mountains, large strip mines to extract phosphate are located in the Bear River watershed in Idaho and Utah (Mars and Crowley 2003), and this river is the largest source of water for the Great Salt Lake. In addition to phosphorus, these mines release significant quantities of selenium (Hamilton and Buhl 2005). Industrial activities in the greater metropolitan Salt Lake City have included metallurgical plants, railroad maintenance, petroleum refining and other

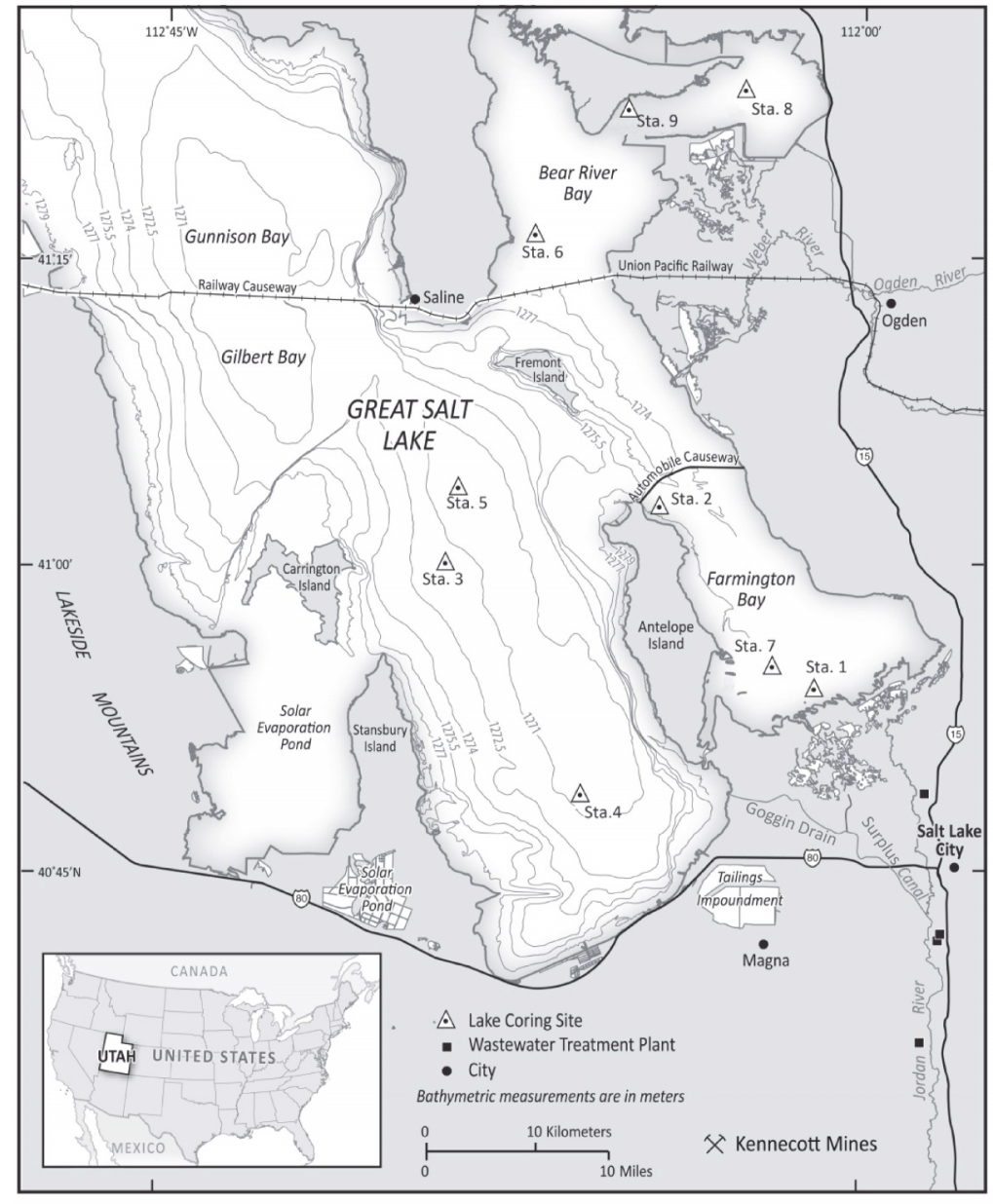

Figure 1. Map of the Great Salt Lake showing the coring sites, causeways, and small $\left(\bullet,<50 \mathrm{~L} \mathrm{sec}^{-1}\right)$ and large $\left(\bullet,>100 \mathrm{~L}^{-1} \sec ^{-1}\right)$ wastewater treatment plant locations. The location of the Bingham Canyon porphyry copper mine (Kennecott Mines) is also shown. 
manufacturing that have also released metals into the Great Salt Lake watershed and air shed (The Forrester Group 2001).

The accumulation of metals near the Salt Lake area has been measured previously utilizing sediment cores retrieved from lakes that record the chronology of deposition. Kada et al. (1994) indicated that metal contaminants from river inputs likely contaminated Echo and Deer Creek Reservoirs located just east of the Salt Lake Valley. More recently, a network of sediment records showed metal contamination in several Salt Lake Valley sites (Naftz et al., 2000). More

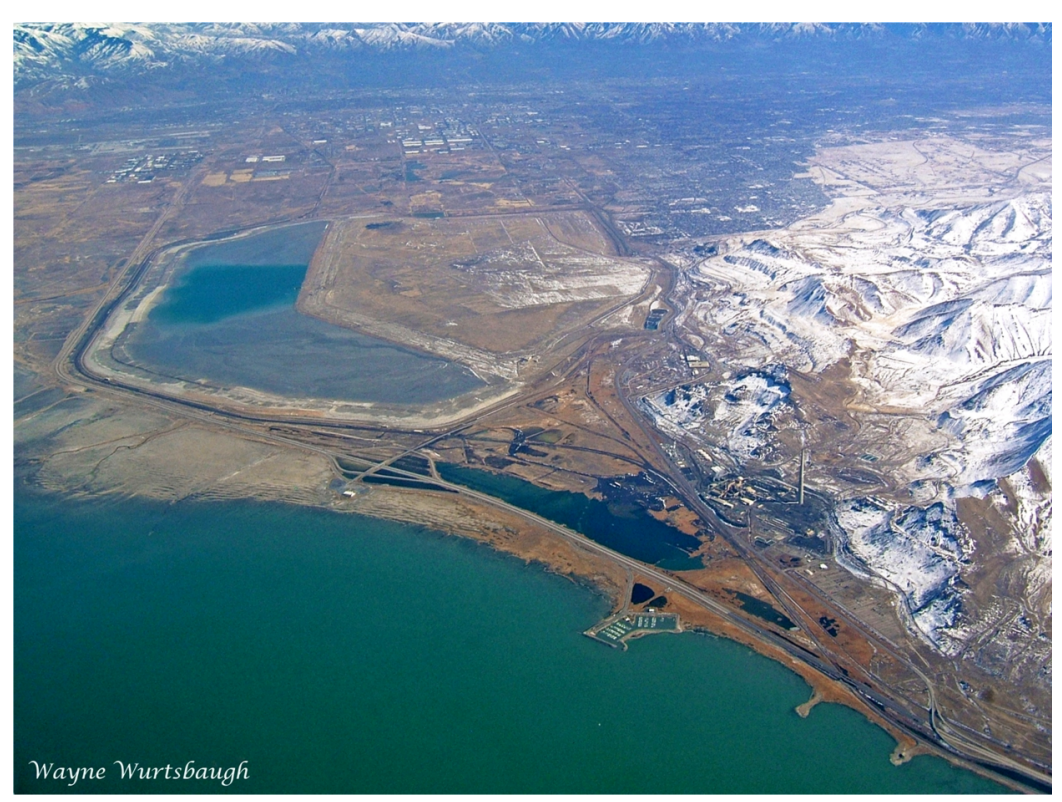

Figure 2. Aerial view of the Kennecott Corporation (Rio Tinto) smelter (lower right) and its tailings pond (upper left), both located on the south shore of Gilbert Bay, Great Salt Lake. Salt Lake City is in the background. Photo 9 March, 2012.

remote sites have also been

affected by metal pollution from the Salt Lake Valley. For example, remote Mirror Lake, located in the Uinta Mountains $100 \mathrm{~km}$ from the Salt Lake Valley, received atmospheric inputs of metals beginning in the early 1900s (Kada et al., 1994). Additional paleolimnological research in these mountains demonstrated unequivocally that the source of the metals to these alpine lakes was from atmospheric dust originating from smelters processing the ores of the Oquirrh and Wasatch Mountains (Moser et al. 2010; Reynolds et al. 2010). Although smelting activities are frequently associated not only with metals deposition, but also the acidification of lakes and streams, this has not been a major problem for these lakes. For lakes closest to the Salt Lake Valley this is probably related to the underlying bedrock. which is comprised of limestone and dolomites that buffer acidification (Ellis 1986). In the Uinta Mountains the underlying quartzite bedrock offers little buffering capacity, but it is believed that aeolian alkaline dust from the west desert of Utah reaches these watersheds and provides the needed buffering (Ellis 1986).

Despite this previous research, analyses of metal contamination in the Great Salt Lake have been limited because bioaccumulation in fish has not been a concern in this hypersaline system that only has abundant fish in its estuaries. However, in recent years concern has increased that bioaccumulation of metals through the food chain could affect the large populations of migratory birds that utilize the high productivity of the lake to fuel their migrations (Aldrich and Paul 2002; Cavitt 2007; Vest et al. 2009; Cline et al. In prep.). In a preliminary analysis, Waddell et al. (2002) found relatively high levels of selenium and other metals in the brine shrimp and brine flies that are the dominant food sources for migratory birds (Aldrich and Paul 2002; Wurtsbaugh 2009; Roberts 2013). The finding of high selenium levels, combined with a permit application by the Kennecott Copper Corporation to discharge additional selenium into the lake led to an extensive examination of this contaminant in the ecosystem (UDWQ 2008). Naftz et al. (2008) documented excessively high levels of total and methyl mercury in parts of the 
Great Salt Lake, and this was followed by a coordinated study to assess sources and bioaccumulation of this toxin in the system (Naftz et al. 2009a; UDEQ 2011; Wurtsbaugh et al. 2011). Finally, an extensive analysis of many metals and other toxins in the Great Salt Lake and its fringing wetlands was recently completed that documented metals concentrations that were frequently above Threshold Effects Concentrations (Waddell et al. 2009), which could have detrimental effects to freshwater organisms (Macdonald et al. 2000).

To help understand the degree of metals contamination in the Great Salt Lake, and to evaluate the chronology of this contamination relative to mining history and industrialization, we analyzed two sediment cores from the south arm of the lake (Gilbert Bay), and one from the semi-enclosed Farmington Bay, which also receives significant loading of metals and nutrients from greater metropolitan Salt Lake City. The sediment cores allowed us to evaluate 150-200 years of metals deposition in the ecosystem. Additionally, surface sediments were analyzed from five other sites in the lake to assess the spatial extent of contamination. The results for Gilbert Bay show that the deposition of most metals began in the late 1800 s and peaked at high levels in the mid-1900s, and have since declined. Selenium and arsenic, however, continue to increase in the sediment record, as have most metals in Farmington Bay.

\section{Study Site and Methods}

Study Site-The Great Salt Lake (Fig. 1) is a $5200 \mathrm{~km}^{2}$ closed-basin system in Utah, USA (41.04 N, $112.28 \mathrm{~W}$ ) bordered on its eastern and southeastern shores by the Salt Lake City metropolitan area with over a million residents. The lake has been impacted by industrial and municipal discharges, as well as by transportation causeways that divide the system into four large bays (Fig. 1). The main body of the lake was divided in two by a railway causeway constructed in 1959. Culverts and a breach allow exchange of water and salts. However, salinity in the northern arm of the lake, Gunnison Bay $\left(2520 \mathrm{~km}^{2}\right)$ is normally at saturation (ca. $330 \mathrm{~g} \mathrm{~L}^{-1}$ ). The southern arm of the lake, Gilbert Bay, covers approximately $2400 \mathrm{~km}^{2}$, but lake area, depth, volume and salinity vary greatly with precipitation cycles. Since 1850 , surface salinities in Gilbert Bay have varied from 60 to $\sim 330 \mathrm{~g} \mathrm{~L}^{-1}$. At the mean lake elevation of $1280 \mathrm{~m}$, the mean and maximum depths of Gilbert Bay are 4.4 and $10.1 \mathrm{~m}$ (Baskin 2005). Gilbert Bay, however, receives an underflow of saturated brine from Gunnison Bay that passes through the causeway's culverts and fill material, so that $\sim 50 \%$ of the southern bay is underlain by a deep brine layer (monimolimnion) that is anoxic and has high concentrations of hydrogen sulfide (Gwynn 2002a; Jones and Wurtsbaugh 2014). Stephens (1990) provides a historical review of the effects of salinity changes in Gilbert Bay to the lake's biota.

The two bays on the eastern side of the lake receive freshwater inflows from the Wasatch and Uinta mountains, and can be characterized as estuaries with salinities that vary from freshwater to hypersaline conditions, both spatially, and on seasonal and decadal time scales. Farmington Bay ( $\sim 310$ $\mathrm{km}^{2}$ ) in the SE is shallow, with a mean depth of only $1.1 \mathrm{~m}$ at mean lake elevation (EPA 2010). It receives flows from the Jordan River that passes through Salt Lake City and wetlands before reaching the lake and by smaller creeks on its eastern side of the bay. At lake elevations above approximately $4201 \mathrm{~m}$ Farmington Bay was joined on the north and south to Gilbert Bay, but at lower lake levels Antelope Island was contiguous with the mainland, thus partially isolating the bay (Fig. 1). In 1952 an automobile causeway was constructed to the southern tip of Antelope Island, thus reducing interchange with Gilbert Bay even when lake levels were above $4201 \mathrm{~m}$. In 1969 another automobile causeway was constructed to 
the northern tip of Antelope Island with only two small culverts and a bridge that allows water to exchange between Farmington and Gilbert Bays. Both automobile causeways were flooded in the mid1980's when the lake reached an historic high level of $4211 \mathrm{~m}$. The overall influence of the two automobile causeways, however, has been to make Farmington Bay fresher, with salinities ranging spatially and temporally from $<1 \mathrm{~g} \mathrm{~L}^{-1}$ up to $90 \mathrm{~g} \mathrm{~L}^{-1}$ (Wurtsbaugh and Marcarelli 2006). A salt wedge intrudes from Gilbert Bay so that the northern half of Farmington Bay is underlain with an anoxic, hydrogen-sulfide rich deep brine layer below a depth of $\sim 1 \mathrm{~m}$ (Bioeconomics 2012). Bear River Bay in the NE has an area of $212 \mathrm{~km}^{2}$ and a mean depth of only $0.6 \mathrm{~m}$ at mean lake elevation (EPA 2010). In the late 1960s interchange between Bear River Bay and Gilbert Bay was constricted by construction of salt ponds and a bridge by the Great Salt Lake Minerals Corporation (Behrens 1980). Bear River Bay receives flows from the lake's largest tributary, the Bear River, and thus has fresh water during spring runoff, but salinities can climb to over $250 \mathrm{~g} \mathrm{~L}^{-1}$ when the bay dries and concentrates salts that have entered the bay from the adjoining salt ponds and/or Gilbert Bay (Tiffany et al. 2007a).

In addition to the causeways that have modified the lake's circulation and salinities, other changes have occurred since the settlement of Salt Lake City by Mormon pioneers in 1847 (Table 1). The human population and accompanying industrial development on the shores of the lake have increased rapidly: 8,000 in 1850; 143,000 in 1900; 389,000 in 1950, and; 1,570,000 in 2010 (Counties of Salt Lake, Davis and Weber; Tiffany et al. 2007b)). To reduce flooding during spring runoff, the Surplus Canal was constructed in 1885 to divert water from the Jordan River from a point south of Salt Lake City and into the wetlands bordering the southern edge of Farmington Bay (Fig. 1). In 1952 the Surplus Canal was joined with the Goggin Drain so that flood waters could be diverted into Gilbert Bay (Deseret News 1952). An analysis of flows from 1975 to 1984 suggests that an average of $36 \%$ of the Jordan River's flow is diverted into Gilbert Bay via the Goggin Drain (CH2MHill 2012). The majority of these flows to Gilbert Bay are during spring runoff when wastewaters are diluted. In 1889, the first sewer system in Salt Lake City began discharging raw sewage into the Jordan River, but by 1911 conditions in the river were so bad that a Sewer Canal was constructed to bypass the Jordan River and discharge sewage directly to Farmington Bay (Hooton no date). In 1922, the Northwest Oil Drain was connected to the Sewer Canal to discharge industrial wastes from refineries and other industries in the NE part of Salt Lake City (Fig. 3). Because of the metals and other contaminants that have accumulated in the NW

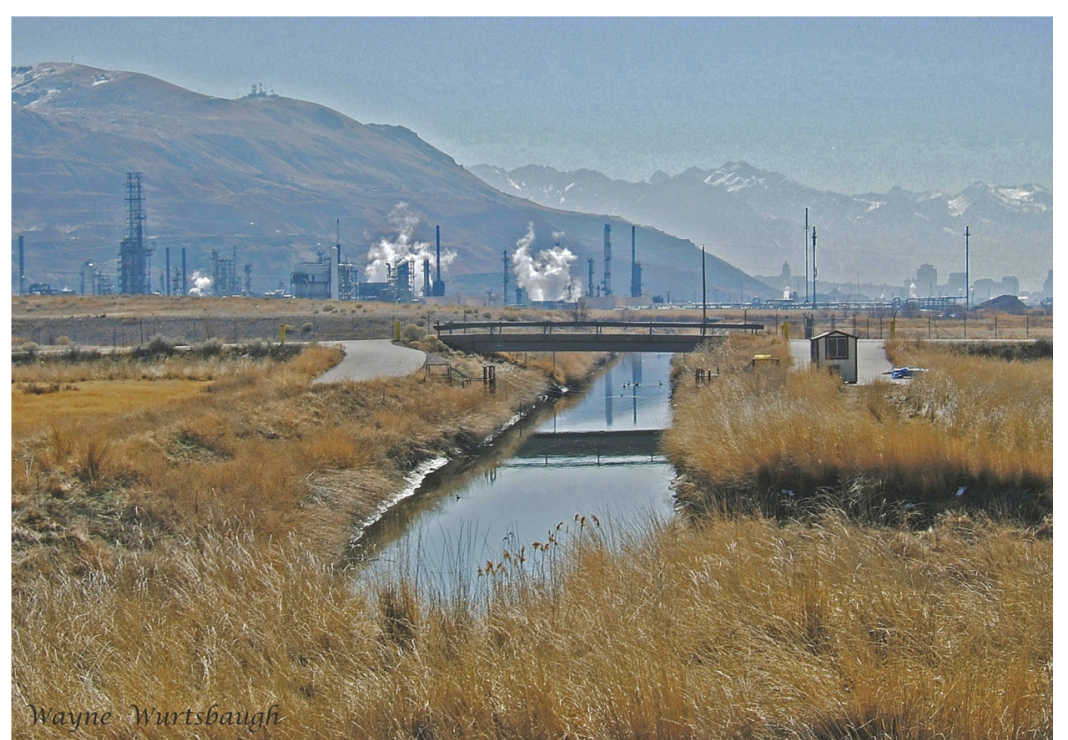

Figure 3. Northwest Oil Drain and refineries in northern Salt Lake City. The Oil Drain joins the Salt Lake City Sewer Canal and enters the lake at the south end of Farmington Bay. The State Capitol and high-rise buildings of Salt Lake City are visible in the upper right. The Wasatch Mountains are in the background. Photo 9 March 2012. 
Oil Drain, it is now an EPA Superfund Cleanup Site (The Forrester Group 2001). In addition to the industrial activities of the growing city, the mining activities in the immediate region have contributed to high metals loading to the lake. Water quality conditions in

\begin{tabular}{|c|c|}
\hline Year & Event \\
\hline 1847 & Mormon pioneers settle Salt Lake Valley. \\
\hline 1863 & Copper mining begins at Bingham Mine; intensifies in 1873. \\
\hline 1873 & Lake reaches high level $\left(4211^{\prime} ; 1283.5 \mathrm{~m}\right)$, but salinity only decreases to $\sim 136 \mathrm{~g} \mathrm{~L}^{-1}$. \\
\hline 1885 & Surplus Canal constructed that diverts flood flows of Jordan River to wetland at the south end of Farmington Bay \\
\hline 1889 & First sewer line in SLC to the Jordan River; by 1908 flow was $0.60 \mathrm{~m}^{3} \mathrm{sec}^{-1}\left(21 \mathrm{ft}^{3} \mathrm{sec}^{-1}\right)$. \\
\hline 1892 & First smelter for gold, silver and lead. \\
\hline 1906 & $\begin{array}{l}\text { Agriculturists win lawsuit against four Salt Lake Valley smelters, forcing them to reduce emissions of sulfuric acid } \\
\text { and arsenic. }\end{array}$ \\
\hline 1911 & $\begin{array}{l}\text { Outlet Sewage Canal completed to the Great Salt Lake (Farmington Bay). Flow discontinued into the Jordan } \\
\text { River. }\end{array}$ \\
\hline 1922 & The current Oil Drain - Sewage Canal to the Great Salt Lake completed. \\
\hline 1930 & $\begin{array}{l}\text { Farmington Bay Waterfowl Management Area constructed. Diking likely helps retain Jordan River nutrients and } \\
\text { sediments in wetlands. }\end{array}$ \\
\hline 1952 & $\begin{array}{l}\text { Goggin Drain connected to Surplus Canal so that spring floods of Jordan River can be diverted to Gilbert Bay. } \\
\text { Record flood in Jordan River. }\end{array}$ \\
\hline 1952 & $\begin{array}{l}\text { South causeway to Antelope Island constructed to prevent raw sewage from reaching swimming beaches at } \\
\text { south end of Gilbert Bay when high lake levels flooded the sill to the Island. Sewage would have been "treated" } \\
\text { longer in Farmington before reaching Gilbert. }\end{array}$ \\
\hline 1959 & $\begin{array}{l}\text { Railroad Causeway completed that separates Gilbert and Gunnison Bay. Causes salinity to decrease in Gilbert, } \\
\text { but deep brine layer begins to form. }\end{array}$ \\
\hline $\begin{array}{l}1959 \text { to } \\
1962\end{array}$ & $\begin{array}{l}\text { Three sewer districts formed in Davis Co. to discharge wastewater into Farmington Bay. Combined flow ca. } 265 \\
10^{3} \mathrm{~m}^{3} \text { day }^{-1} \text { (70 million gallons per day). }\end{array}$ \\
\hline 1963 & $\begin{array}{l}\left.\text { Lake reaches lowest recorded level ( } 1277.8 \mathrm{~m} ; 4192.2^{\prime}\right) . \text { Deep brine layer in Gilbert likely disappeared. South } \\
\text { end of Farmington Bay would have been just river/wastewater flow (or dry, depending on where river channel } \\
\text { went.) }\end{array}$ \\
\hline 1965 & Secondary treatment facility completed in Salt Lake City; discharge of raw sewage stopped. \\
\hline 1969 & $\begin{array}{l}\text { Automobile causeway to Antelope Island completed, partially isolating Farmington Bay. Top elevation } 1282.1 \mathrm{~m} \\
(4206.5 \mathrm{ft}) \text {. }\end{array}$ \\
\hline 1970 & Clean Air Act of US; 1977 signficant increases in regulations. \\
\hline 1984 & Automboile causeway to Antelope Island flooded by high water until mid-1989. \\
\hline 1985 & Gilbert Bay reaches record high level $\left(4208.85^{\prime} ; 1282.86 \mathrm{~m}\right)$; Salinity declindes to $58 \mathrm{~g} \mathrm{~L}^{-1}$. \\
\hline 1992 & Automobile causeway rebuilt. \\
\hline
\end{tabular}

Table 1. Dates of important events that have influenced contaminants in the Great Salt Lake, Utah. 
Farmington Bay, which received the majority of the wastewater discharges from Salt Lake City, presumably degraded rapidly, although documentation of this is poor. Gwynn (2002b) provides a history of raw and treated sewage discharge into Farmington Bay and reviews the earlier studies. He notes that the sewage discharge resulted in what Van der Meide and Nicholes (1972) called a "sewage delta" near the outfall of the Sewer Canal. Raw sewage was reaching swimming beaches at the south end of Gilbert Bay (Saltair) when the lake was high enough to permit water exchange at the south end of Antelope Island. In 1952 an elevated roadway was constructed to the southern tip of the island, in part to keep raw sewage from reaching the swimming beaches at SaltAir on the south end of Gilbert Bay (Gwynn 2002b).

Recent studies have shown that water quality conditions in the bays of the Great Salt Lake differ markedly (Wurtsbaugh and Marcarelli 2006; Wurtsbaugh et al. 2008). Farmington Bay is hypereutrophic with phosphorus loading ca. $3 \mathrm{~g} \mathrm{~m}^{-2} \mathrm{y}^{-1}$ (Marcarelli and Wurtsbaugh 2005), large blooms of a nitrogenfixing cyanobacteria, Nodularia spumigena, and mean chlorophyll a concentrations of $141 \mu \mathrm{g} \mathrm{L}^{-1}$ (Wurtsbaugh et al. 2012). Oxygen concentrations range from supersaturated during the day to anoxia throughout the water column at night. $\mathrm{pH}$ varies with the diel swings in photosynthesis with values ranging from ca. 8.6-9.5 (Tiffany et al. 2007a; Wurtsbaugh et al. 2012). Temperatures in the shallow bay reach $30^{\circ} \mathrm{C}$ during the daytime in summer, and the bay is ice covered in the winter. Strong temporal and spatial salinity gradients (1-90 $\left.\mathrm{g} \mathrm{L}^{-1}\right)$, however, cause blooms of Nodularia to vary greatly. Depending on salinities, phytoplankton in Farmington Bay can be limited by either nitrogen or phosphorus (Marcarelli et al. 2006). Although all sewage now entering the bay has had secondary treatment, some evidence of human pathogens is present in the bay's sediments (Gast et al. 2011). Sorensen et al. (1988) also found hypereutrophic conditions and a dominance by Nodularia in 1986 when the lake was at a high level and the Antelope Island Causeway was flooded. Naftz et al. (In preparation) found total and methyl mercury concentration in Farmington Bay of 8 and $2 \eta \mathrm{g} \mathrm{L}^{-1}$, respectively. Total selenium concentrations were near $0.5 \mu \mathrm{g} \mathrm{L}^{-1}$ (Naftz et al. 2009b).

Gilbert Bay, with recent salinities between 100 and $160 \mathrm{~g} \mathrm{~L}^{-1}$ is much less productive than Farmington Bay. The brine is composed of $55 \% \mathrm{Cl}, 28 \% \mathrm{Na}, 8 \% \mathrm{SO}_{4}, 4 \% \mathrm{Mg}$ and $5 \%$ other salts (Sturm 1980). Oxygen concentrations are usually near saturation in the mixed layer, but are zero in the deep brine layer below $\sim 6.5 \mathrm{~m}$. Temperatures reach $24^{\circ} \mathrm{C}$ in summer and can decline to $0^{\circ} \mathrm{C}$ or below in winter. The $\mathrm{pH}$ is relatively stable around 8.1 in the mixed layer (Wurtsbaugh and Marcarelli 2006). This bay is dominated by green algae and abundant populations of Artemia and Ephydra (Felix and Rushforth 1979; Wurtsbaugh and Marcarelli 2006; Wurtsbaugh et al. 2011). Chlorophyll $a$ concentrations vary seasonally, with highs near $70 \mu \mathrm{g} \mathrm{L}^{-1}$ in winter, to ca. $1 \mu \mathrm{g} \mathrm{L}^{-1}$ in summer when grazing by Artemia depresses the phytoplankton populations. Phytoplankton growth is limited by nitrogen when salinities are $>70 \mathrm{~g} \mathrm{~L}^{-1}$ because cyanobacteria cannot fix atmospheric nitrogen at those levels (Stephens and Gillespie 1976; Wurtsbaugh 1988; Marcarelli et al. 2006). Wurtsbaugh et al. (2008) estimated that nitrogen loading to Gilbert Bay was high $\left(>2.4 \mathrm{~g} \mathrm{~m}^{-2} \mathrm{yr}^{-1}\right)$, with approximately $45 \%$ contributed by the outflow from Farmington Bay. Total mercury and selenium concentrations in the mixed layer of Gilbert Bay are near $5 \eta \mathrm{g} \mathrm{L}^{-1}$ and $0.5 \mu \mathrm{g} \mathrm{L}^{-1}$, respectively, but much higher mercury concentrations occur in the deep brine layer (Naftz et al. 2008; Jones et al. 2009; Wurtsbaugh et al. 2011; Jones and Wurtsbaugh 2014). Less information is available concerning water quality in Bear River Bay, but mean chlorophyll levels are near $22 \mu \mathrm{g} \mathrm{L}{ }^{-1}$ (Wurtsbaugh et al. 2012). Total selenium concentrations are ca. $0.5 \mu \mathrm{g} \mathrm{L}^{-1}$ in the bay and total mercury concentrations in an adjacent diked wetland are ca. $2 \eta \mathrm{g} \mathrm{L}^{-1}$ (Naftz et al. 2009b; Naftz et al. In preparation). Water quality conditions in Gunnison Bay, with salinities 
that are usually near saturation and a near absence of metazoan organisms, has been studied less than the other bays, with a focus on microbial diversity and function (Post 1981; Parnell et al. 2011).

Table 2. Coring site locations and characteristics.

\begin{tabular}{|c|c|c|c|c|c|c|c|c|}
\hline \multirow[b]{3}{*}{ Site Chacteristics } & \multicolumn{8}{|c|}{ Bay and Site Number } \\
\hline & \multicolumn{3}{|c|}{ Farmington Bay } & \multicolumn{3}{|c|}{ Gilbert Bay } & \multicolumn{2}{|c|}{ Bear River } \\
\hline & 1 & 2 & 7 & 3 & 4 & 5 & 6 & 8 \\
\hline & $40.91425 \mathrm{~N}$ & $41.05844 \mathrm{~N}$ & $40.93177 \mathrm{~N}$ & $41.00905 \mathrm{~N}$ & $40.82507 \mathrm{~N}$ & $41.07202 \mathrm{~N}$ & $41.27657 \mathrm{~N}$ & $41.39331 \mathrm{~N}$ \\
\hline Coordinates & -112.04996 W & $-112.21719 \mathrm{~W}$ & $-112.09557 \mathrm{~W}$ & $-112.43955 \mathrm{~W}$ & $-112.29711 \mathrm{~W}-$ & $112.42842 \mathrm{~W}$ & $-112.35191 \mathrm{~W}$ & $-112.12797 \mathrm{~W}$ \\
\hline Collection Date & 17-Aug-09 & 17-Aug-09 & 25-Jun-10 & 18-Aug-09 & 19-Aug-09 & 20-Aug-09 & 21-Aug-09 & 8-Jul-10 \\
\hline Station Depth (m) & 0.15 & 1.01 & 0.68 & 7.35 & 7.8 & 7.94 & 0.12 & 0.7 \\
\hline Bottom Salinity $\left(\mathrm{g} \mathrm{L}^{-1}\right)$ & 1 & 80 & 4 & 147 & 147 & 147 & 145 & 2 \\
\hline Secchi Depth (m) & $\gg 0.15$ & 0.16 & 0.38 & 0.7 & 3.8 & 2.15 & 0.5 (deeper site) & $>0.7$ \\
\hline
\end{tabular}

Coring, Sectioning \& Dating — Coring and sectioning were described in detail by Leavitt et al. (1980). Briefly, cores were collected with a Kajak-Brinkman gravity corer (Glew et al. 2001) with a 63-mm diameter tube at 10 sites in three of the bays of the Great Salt Lake on 17-21 August 2009 and 8-9 July 2010. Site coordinates and depths at the time of collection are given in Table 2. The cores were either processed in the field (2009) or transported upright to the laboratory (2010) and sectioned in $0.5-\mathrm{cm}$ intervals with a Glew push rod extruder (Glew et al., 2001).

The locations of the nine coring sites are shown in Fig.1. Two of the successfully-dated cores were in Gilbert Bay (Site 3, 4) at depths $>7 \mathrm{~m}$ where an anoxic deep brine layer (monimolimnion) was present. The other dated core was at the south end of Farmington Bay. At low water levels this site is in a broad channel running E-W that is partially disconnected from the main bay (Fig. 4). At the time of coring Site 1 was only $0.15 \mathrm{~m}$ deep and ca. $1 \mathrm{~km}$ from the discharge point of the Sewer Canal/NW Oil Drain, but at mean lake elevations it would have been ca. $6 \mathrm{~km}$ from the outfall. At low lake levels, Site 1 might be better characterized as being part of the former Jordan River delta, whereas at mean lake elevation $(1280 \mathrm{~m} ; 4200 \mathrm{ft}$.) water depth would have been ca. $2 \mathrm{~m}$ and it would have mixed well with the main Farmington Bay. Site 1 is near

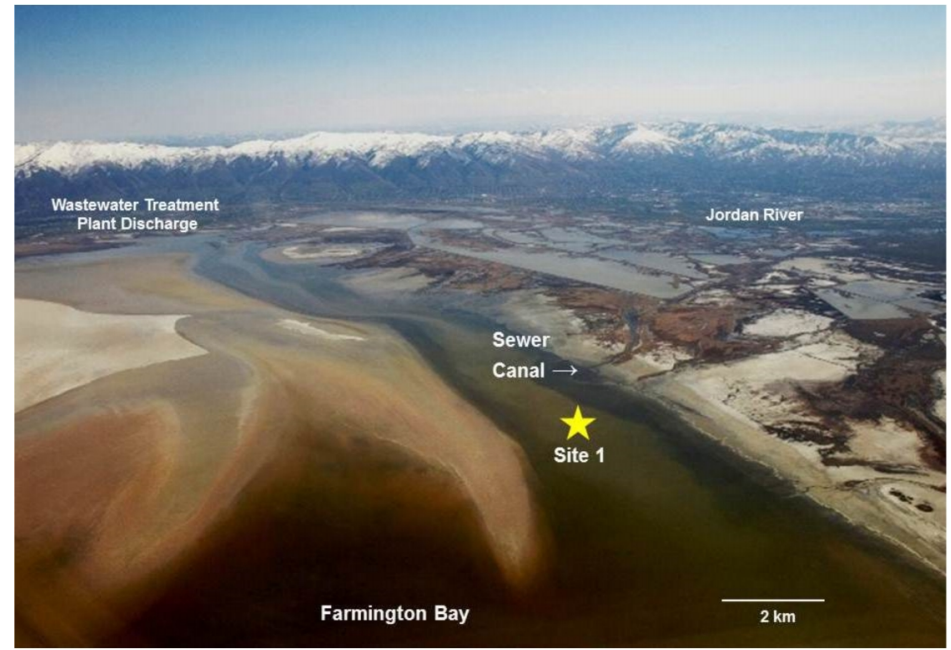

Figure 4. Aerial photograph showing the SE end of Farmington Bay and the location of the Site 1 core. At higher lake levels the sand sill to the north of this site would be inundated and the water would mix more with the rest of the bay. The Site 1 core was taken when Gilbert Bay was at a lake elevation of 1,278.6 m (4,195 ft.). The image was taken 21 April 2008 when Gilbert Bay was at an elevation of 1279 m. Photo by W. Wurtsbaugh. 
the fresh water inflows from the Central Davis Sewer District, the Salt Lake City Sewer Canal, and the Jordan River after it has passed through the wetlands at the south end of the bay (Figs. 1, 4). These inflows create strong salinity gradients along the N-S axis of the bay with nearly fresh water near Site 1, and salinities of 20-90 $\mathrm{g} \mathrm{L}^{-1}$ at the northern end after the construction of the Automobile Causeway (Hayes 1971; Wurtsbaugh and Marcarelli 2006). The strong salinity gradient results in very different plankton communities from north to south (Hayes 1971; Wurtsbaugh and Marcarelli 2006). Consequently, the results for Site 1 should not be interpreted as being characteristic of the entire bay.

${ }^{210} \mathrm{~Pb}$ dating of the cores is described in detail by Leavitt et al. (1980). Briefly, 12-14 core sections were freeze-dried and then counted either at the University of Regina Environmental Quality Analysis Laboratory (Sites 1-3, 6) and University of Waterloo (Sites 4, 5) using gamma spectrometry and an Ortec High-Purity Germanium (HPGe) Coaxial Well Photon Detector System. To validate the ${ }^{210} \mathrm{~Pb}$ dates ${ }^{137} \mathrm{Cs}$ activity was measured to identify the period of maximum fallout from atmospheric nuclear weapons testing (1963-65). Sediment age-depth relations were calculated using the CRS (constant rate of supply) model (Appleby and Oldfield 1983). Bulk sediment accumulation rates $\left(\mathrm{g} \mathrm{cm}^{-2} \mathrm{yr}^{-1}\right)$ were computed from output of the CRS model (Appleby and Oldfield 1983) and represent the mass of dried material (sediments + salt) in each $0.5 \mathrm{~cm}$ interval $\left(\mathrm{g} \mathrm{cm}^{-2}\right)$ divided by the time represented in the interval (yr.). Dates earlier than $\sim 1875$ CE (Common Era, formerly AD) were approximated by extrapolation of mass accumulation rates.

The dating chronologies for the three cores are shown in Fig. 5 and a detailed description of these results is available in Leavitt et al. (2012). The Site 4 core in Gilbert Bay yielded a confirmatory cesium peak in the mid-1960s. In the Site 3 core the expected mid-1960s ${ }^{137} \mathrm{Cs}$ peak occurred between 1928-1942 (based on the ${ }^{210} \mathrm{~Pb}$ depth estimate), making the chronology at this site less dependable. Consequently, we have relied more on the Site 4 core for interpretation of the chronology in Gilbert Bay. Nevertheless, the patterns seen at Sites 3 and 4 were relatively similar (see Results). The Site 1core also had a cesium peak in the mid-1960s, but the peak was distorted in the surface sediments due to either sediment mixing or post-depositional migration of ${ }^{137} \mathrm{Cs}$ (see Leavitt et al. 2012). Of the ten cores collected, seven did not yield useful ${ }^{210} \mathrm{~Pb}$ chronologies, likely because in many of the shallow sites wind mixing has homogenized the sediments so that useful temporal resolution was lost. Nevertheless, we analyzed the upper $0-1 \mathrm{~cm}$ of sediments from five of these sites to provide an estimate of the spatial variation across Great Salt Lake.

Analytical Methods for Metals — Sediment subsamples from each core slice were oven-dried at $70^{\circ} \mathrm{C}$ until constant weight was obtained. Metal concentrations in the sediment samples were measured at the Utah Veterinary Diagnostic Laboratory (http://www.usu.edu/uvdl/) in Logan, Utah. The nitric acid leachable mineral concentrations in each slice were quantified using inductively coupled plasma mass spectroscopy (ICP-MS). Test materials were digested in screw-cap Teflon tubes on a heat block at $90^{\circ} \mathrm{C}$ for 4 hours. Weighed sediment samples $(\sim 0.5 \mathrm{~g})$ were digested in $10 \mathrm{ml}$ trace mineral grade nitric acid. The digests were diluted 1:20 with 18.2 MOhm ultrapure water, to provide a 5\% nitric acid matrix prior to analysis. This resulted in a matrix match to the standards and quality control samples. Samples that had higher mineral content than the high standard were diluted $1: 10$ in $5 \%$ nitric acid and reanalyzed. Standard curves for all elements, except mercury, consisted of five concentrations between 10 and 2500 $\mu \mathrm{g} 1^{-1}$. Standard curves for mercury consisted of three concentrations from 2.5 to $10 \mu \mathrm{g} \mathrm{l}^{-1}$. A quality control (QC) test sample was analyzed with every five samples to validate analytical accuracy. The QC 
sample had to be $+/-5 \%$ of the known mineral specifications to pass. Any group of samples that had a failed QC test was re-analyzed. A small number of samples for silver yielded values below detection. For these we assumed that concentrations were $80 \%$ of the detection limit because adjoining samples in the cores had values just slightly over the detection limit.

The metals concentration in each core slice were salt-corrected, to account for the dissolved salts in the interstitial water. Consequently, most of the data are presented on a per-gram of dry sediment basis. The salt correction was particularly important in the top 3-6 cm of the Gilbert Bay cores which had unconsolidated sediment and consequently contained considerable amounts of water and salt. The water content was measured by weight loss during freeze-drying of the samples used for ${ }^{210} \mathrm{~Pb}$ analyses. Salt content was then estimated by multiplying this amount of water by the salt content of the overlying water (Table 2) using the assumption that diffusion of salts would bring the pore water into equilibrium with the overlying water. In the surface 3-4 cm of the Gilbert Bay cores, the salt in the interstitial water accounted for about $50 \%$ of the dry weight of material, so that the salt correction approximately doubled the estimate of metals in these samples. Mean metal concentrations prior to 1860 were assumed to represent background levels, and were used to calculate contamination indices for metals in more recent strata.

Historical Production of Metals in Utah-The annual production of many commercial metals in the State of Utah were obtained from the Utah Geological Survey (2011a). Most of these minerals were processed in Salt Lake Valley or the Tintic/Mercur mining districts that are within $40 \mathrm{~km}$ of the Great Salt Lake (Ege 2005). Although small amounts of mercury have been mined in Utah, mercury residues in the lake may have originated initially from imported mercury used to extract gold and silver with the mercury amalgamation process, and subsequently from mercury released in the smelting polymetallic replacement deposits containing lead and zinc (Plumlee et al. 1996), as well as from other sources of contamination. Consequently, as a metric for mercury use and production, we have used the annual extraction of lead in the State. This is not ideal, however, because of the multiple potential sources of mercury contamination.

Indices and Criteria-Following the approach of (Hokanson 1980), Belzile et al. (2004) and others, we have calculated indices that allow chronologies of multiple metal concentrations to be easily compared. A Contamination Index throughout a core was calculated as the ratio of the concentration of a metal relative to the mean concentration in pre-industrial sediments (before 1860). A Maximum Contamination Index was calculated at the maximum concentration encountered in a core relative to the pre-industrial mean concentration. A Current Contamination Index was calculated as the ratio of the mean concentration in recent sediments (top $1-\mathrm{cm}$ ) relative to the mean background concentration observed in the core prior to 1860. Because of the unusual chemistry and biota in many parts of the Great Salt Lake, site-specific criteria have not been established for assessing the degree of impact a particular metal might have. Nevertheless, to provide some context for understanding the concentrations of metals in the Great Salt Lake sediments we have used freshwater sediment Threshold Effects Concentrations (TEC) where some impacts on biota may be possible, and Probable Effects Concentrations (PEC) where impacts are likely (MacDonald et al. 2000). 
Although these metrics are useful, they do not necessarily mean those criteria can be directly applied to the Great Salt Lake ecosystem, especially in Gilbert Bay where salinities are very high and tolerant saltadapted biota are present.
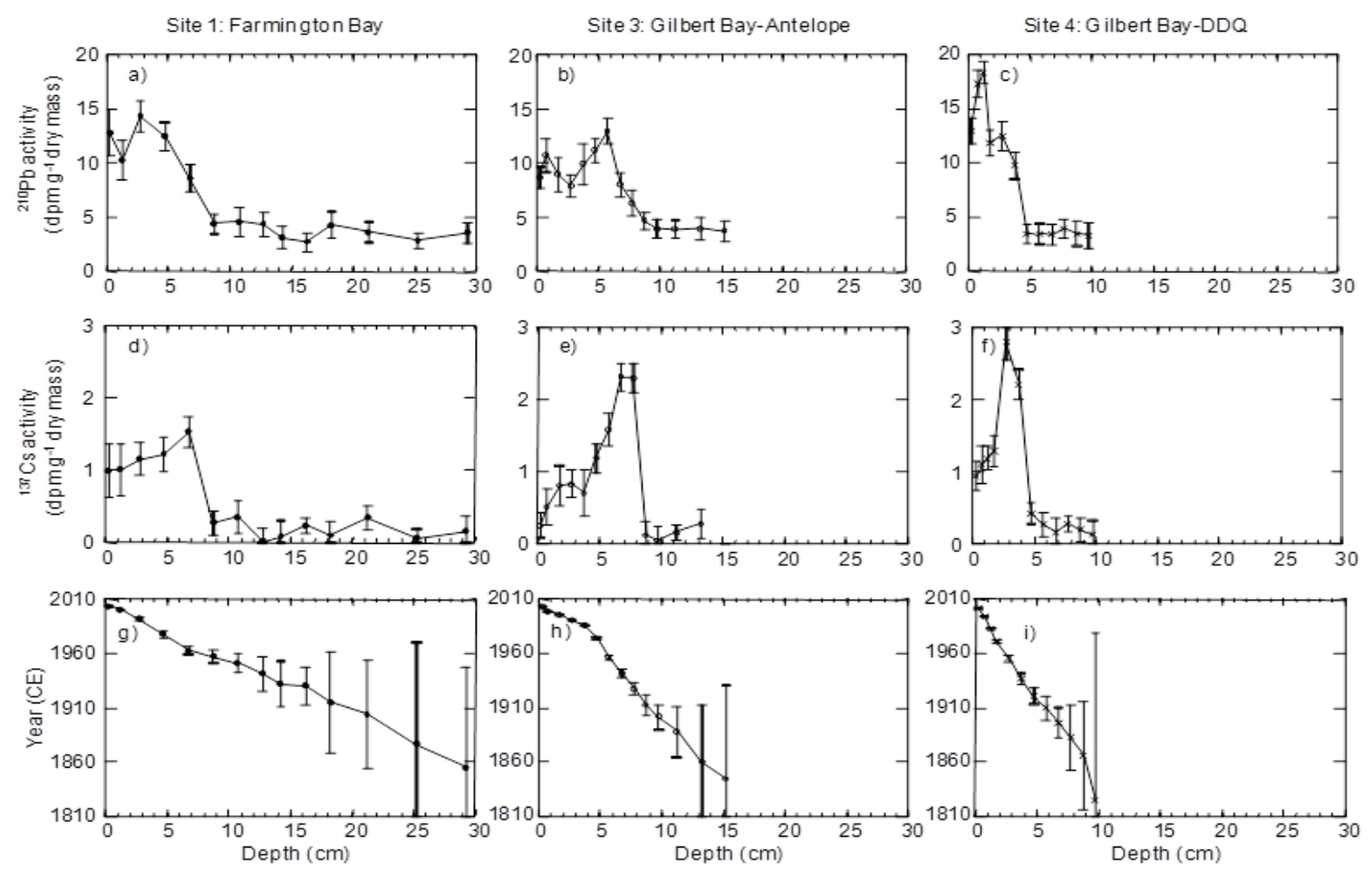

Figure 5. Dating chronologies for Site 1 in Farmington Bay and Sites 3 and 4 in Gilbert Bay. The top row shows ${ }^{210}$ lead activities (disintegrations per minute, dpm) uncorrected for background (supported) activity. The middle row shows ${ }^{137}$ cesium activity and the last row shows estimated dates and s.d. error bars based on variances in ${ }^{210} \mathrm{~Pb}$ counts. From Leavitt et al. 2012.

\section{Results}

\section{Historical changes in metals concentrations}

Gilbert Bay-Analyses of both cores in Gilbert Bay indicated that many metals began increasing in the sediment record in the late 1800 s and early 1900 s coincident with mining and smelting activities, peaked in the mid-1950s and have since declined (Fig. 6, Appendix 1a, 1b). For example, at both sites copper concentrations rose steadily from background levels of $11 \mu \mathrm{g} \mathrm{g}^{-1}$ before the onset of commercial mining to concentrations of $500 \mu \mathrm{g} \mathrm{g}^{-1}$ when copper extraction reached 250,000 metric tons per year in the $1950 \mathrm{~s}$. Since the 1950-1960s, concentrations of copper in the sediment record have decreased markedly: however, in surficial sediments they are still 10-20 times higher than background levels. These declines have occurred despite an overall increase in copper production in the past two decades. 

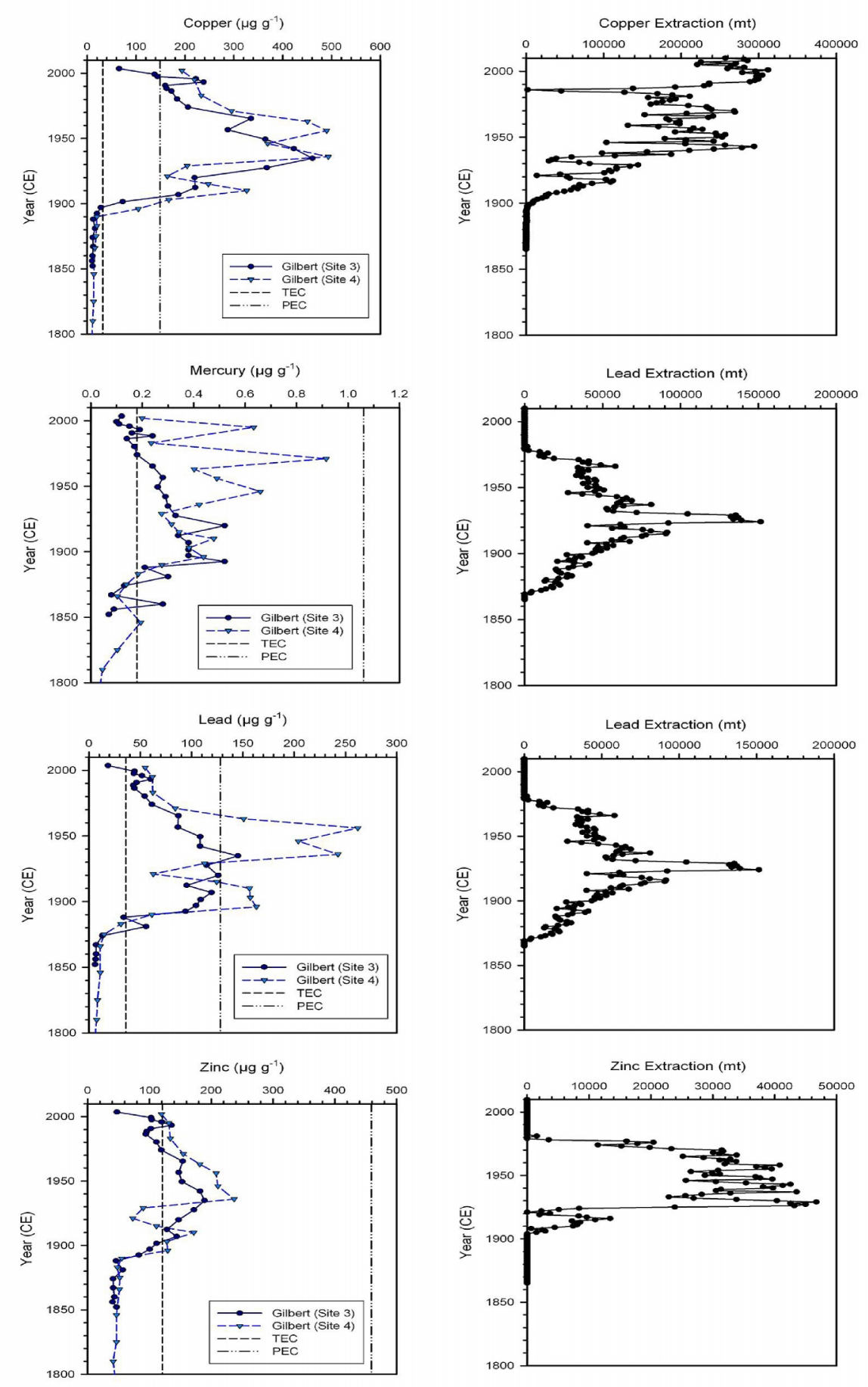

Figure 6. Left frames: Concentrations of $\mathrm{Cu}, \mathrm{Hg}, \mathrm{Pb}$ and $\mathrm{Zn}$ in sediments of different ages from the two coring sites in Gilbert Bay. Concentrations are salt-corrected. Dotted vertical lines show Threshold Effects Concentrations (TEC; ---) and Probable Effects Concentrations (PEC; ---) of sediments in fresh water ecosystems. Right frames: Metal production in Utah derived from Utah Geological Survey (2011b). Note that although zinc was mined along with lead, it was not valued as a commodity until the early 1900s (K. Krahulec personal communication). 
was more variable. Background mercury concentrations were near $0.1 \mu \mathrm{g} \mathrm{g}^{-1}$. When lead production increased sharply in the 1870 s and 1880 s, mercury concentrations began to increase (Fig. 6). Mercury concentrations in the sediments from Site 3 peaked at $0.52 \mu \mathrm{g} \mathrm{g}^{-1}$ in about 1920 , and have declined significantly to levels near $0.12 \mu \mathrm{g} \mathrm{g}^{-1}$ in the surface sediments. At Site 4 the overall trend is similar, but with a much more irregular decline over the last half century.

Lead and zinc concentrations had similar chronologies in the two Gilbert Bay cores (Fig. 6). Both had low background concentrations of $7(\mathrm{~Pb})$ and $45(\mathrm{Zn}) \mu \mathrm{g} \mathrm{g}^{-1}$, but concentrations increased in the late 1800 s and early 1900s, coinciding with the onset of lead and zinc production. Concentrations of lead and zinc in the sediments peaked in the early 1930s (Site 3) or mid-1940s (Site 4) at levels far above background and subsequently declined. As with mercury, the sediment record for lead and zinc concentrations were more variable at Site 4 than at Site 3. Although lead and zinc production in Utah has declined to zero in Utah, and although sediment concentrations have declined substantially, sediment concentrations remain well above background at both sites.

In contrast to most metals, concentrations of selenium and arsenic have been stable or are increasing in the sediments of Gilbert Bay (Fig. 7). Background concentrations of selenium were near 1 $\mu \mathrm{g} \mathrm{g}^{-1}$ at both sites. Concentrations did not increase significantly until the 1930s-1950s, and then have remained relatively constant or increased slightly, reaching concentrations of 4-6 $\mu \mathrm{g} \mathrm{g}^{-1}$ in recent sediments. Background levels of arsenic were near $13 \mu \mathrm{g} \mathrm{g}^{-1}$ and began increasing during the same period when selenium was increasing. Concentrations of arsenic in recent sediments reached 30-50 $\mathrm{g} \mathrm{g}^{-1}$ at both sites.

An indicator of fluvial transport of metals, aluminum (Schindler 2012), did not change markedly in the cores (Appendix 2). This suggests that much of the deposition of other metals in the Great Salt Lake has been by atmospheric deposition rather than by riverine transport. Changes in iron and
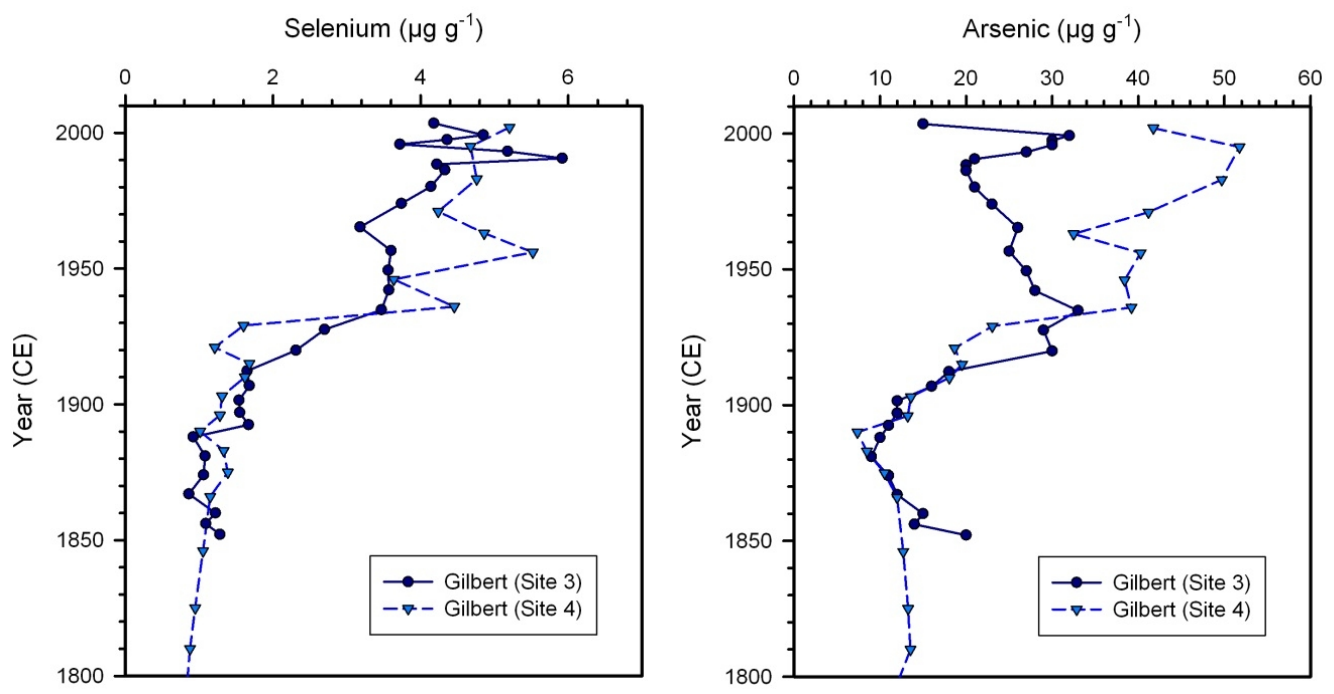

Figure 7. Concentrations of selenium and arsenic from two sediment cores in Gilbert Bay of the Great Salt Lake. Concentrations are expressed $\mu \mathrm{g}$ per gram of salt-corrected dry sediment. 
aluminum concentrations at Site 4, however, did show some parallel changes with other metals after approximately 1910, but this pattern was not evident at the other two coring sites.

Farmington Bay (Site 1) - Our sedimentary record of metals in the Farmington Bay core (Fig. 8; Appendix 1c) differs considerably from the patterns seen in the two Gilbert Bay cores (cf. Fig. $6 \& 8$ ). The estimated chronology for the core samples from Site 1 in Farmington Bay suggests that metal concentrations were near baseline up until the early 1950s when there was a simultaneous and marked increase in most metals. For example, background copper concentrations in the core material were near $11 \mu \mathrm{g} \mathrm{g}^{-1}$ until the early $1950 \mathrm{~s}$, peaked in $\sim 1960$ at concentrations near $200 \mu \mathrm{g} \mathrm{g}^{-1}$ and then stabilized at concentrations near $150 \mu \mathrm{g} \mathrm{g}^{-1}$. Most metals ( $\mathrm{Ag}, \mathrm{Cd}, \mathrm{Cr}, \mathrm{Cu}, \mathrm{Hg}, \mathrm{Mo}, \mathrm{Pb}, \mathrm{Sn}$, and $\mathrm{Zn}$ ) showed this same pattern (Appendix 1c). Copper, mercury, lead, zinc and some other metals are now above threshold effects concentrations in the upper sediments at Site 1 (Fig. 8). The contrast between the abrupt pattern in Farmington Bay and that in Gilbert Bay is shown for copper in Fig. 8a. It is likely that the sediment record in Farmington Bay was not preserved prior to the 1950s, thus yielding an erroneous perception of pristine conditions in the bay in the first half of the century (see Discussion).
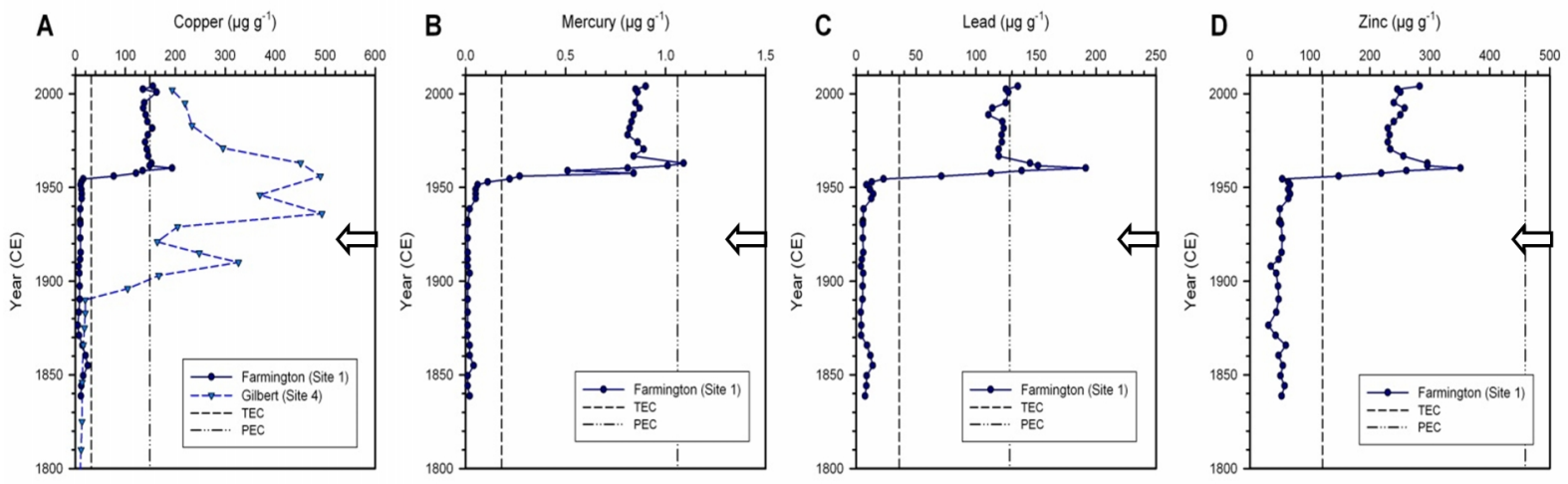

Figure 8. Concentrations of copper (A), mercury (B), lead (C) and zinc (D) is the sediments from a core at the south end of Farmington Bay. Frame A also shows the copper concentrations from Site 4 in Gilbert Bay. The arrow on the left shows the date of completion of the Northwest Oil Drain that began discharging industrial effluents into the bay via the Sewer Canal. Vertical dotted lines show Threshold Effects Concentrations (TEC) and Probable Effects Concentrations (PEC) for fresh water ecosystems. The timing of the onset of metal pollution in Farmington Bay is problematic (see Discussion).

Metal Accumulation Rate-Concentrations of metals in the lake sediments are partly a function of differing sedimentation rates that dilute the metals. Although there were variations through time, Site 4 in Gilbert Bay had the lowest sedimentation rate, Farmington Bay had an intermediate rate, and Site 3 in Gilbert had a somewhat higher rate (Fig. 9a). These rates, when combined with the measured concentrations in the sediments, show the micrograms of each metal that was accumulating per year under a square centimeter of lake bottom. Although sedimentation rates varied spatially and temporally in Great Salt Lake, the general patterns of metal accumulation reflect the trends in metal concentrations (Fig. 6). One notable exception is mercury. Mercury accumulation rates at the two sites in Gilbert Bay were relatively similar, with broad peaks rates around 1900. In contrast, mercury accumulated much faster in 
Farmington Bay than in Gilbert Bay, at least after the mid-1950s (Fig. 9b). Copper accumulation rates in the two Gilbert sites were relatively similar throughout the data record, and after mid-1950s, the Farmington Bay sediments also accumulated this metal at about the same rate (Fig. 9c). Selenium accumulation rates were relatively similar in all three, and all three sites showed increasing rates, particularly in recent sediments (Fig. 9d).

Contamination and Current Indices-The Contamination Indices of the metals that show their concentrations relative to pre-industrial concentrations are shown in Fig. 10. These plots show that many of the trends are dependent on the mining districts, and presumably mining activity, where specific minerals were found. Gilbert Bay's sedimentary concentrations of metals associated with the Bingham Canyon porphyry copper, molybdenum, gold and silver deposits and Mercur gold mining districts are shown in Fig. 10a. Copper, silver, and molybdenum all show similar concentration peaks in the 1950s that were 20 to 40 -fold higher than background concentrations. Silver and copper also show a secondary peak in the relative abundances in the early 1900s.
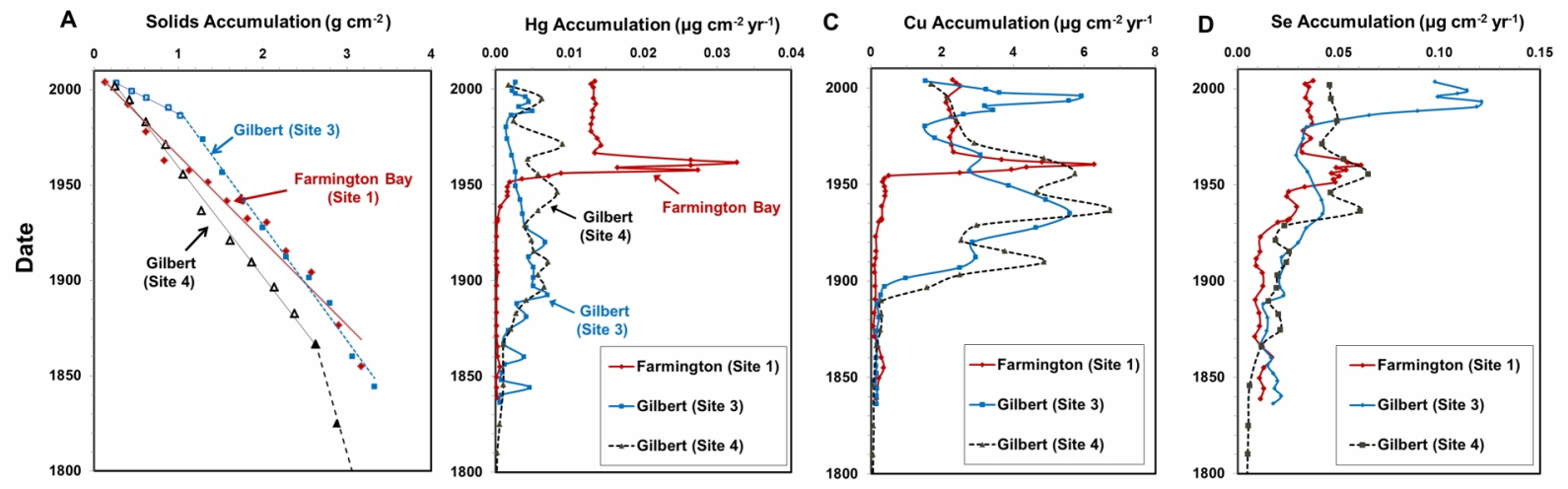

Figure 9. A. Estimated solids (sediment + salt) accumulation rates from two cores collected in Gilbert Bay and one in Farmington Bay. These were used to estimate rates of mercury (frame B), copper (C), and selenium (D) deposition in the sediments of Farmington Bay and Gilbert Bay (2 sites). For the Gilbert Bay sites solids accumulation rates were broken into two phases (Site 3: 1844-1986 and 19862003; Site 4: 1745-1866 and 1866-2002). For Farmington Bay, three phases were recognized (18551930, 1930-1963 and 1963-2004). The accumulation rates are dependent on accurate core dating.

The sediment concentrations of metals from the polymetallic ( $\mathrm{Pb}-\mathrm{Zn}-\mathrm{Cu}-\mathrm{Ag}-\mathrm{Au}$ plus associated $\mathrm{Cd}, \mathrm{As}, \mathrm{Sb}$ and $\mathrm{Hg}$ ) replacement deposits of the Tintic, Park City and Bingham mining districts also showed a similar temporal congruence in their relative abundances in the sediment cores (Fig. 10b). Lead and cadmium had the highest relative increases with peaks about 30 times background levels in the late 1940s. The other metals also peaked at the same time, with tin showing a 14-fold increase whereas zinc increased only $5 \mathrm{X}$ above background levels. Although the temporal pattern for mercury closely followed those for the other from this district, it only increased 9-fold above background levels. As with the porphyry and sedimentary ores from Bingham Canyon and Mercur, the concentrations of metals from the polymetallic replacement deposits have also decreased considerably in the lake sediments since the peak levels in the 1940s and 1950s. 
In contrast to the metals shown in Figs. 10a and 10b, the semi-metals, selenium and arsenic, showed a different concentration pattern in the sediments (Fig. 10c). The origin of these metals is more difficult to characterize. Selenium and arsenic began to increase in the early 1900s and reached moderate levels in the early 1950s. Although the concentration peaks for selenium and arsenic were not particularly high relative to some of the other metals, they are stable or increasing slightly in the recent sediments.
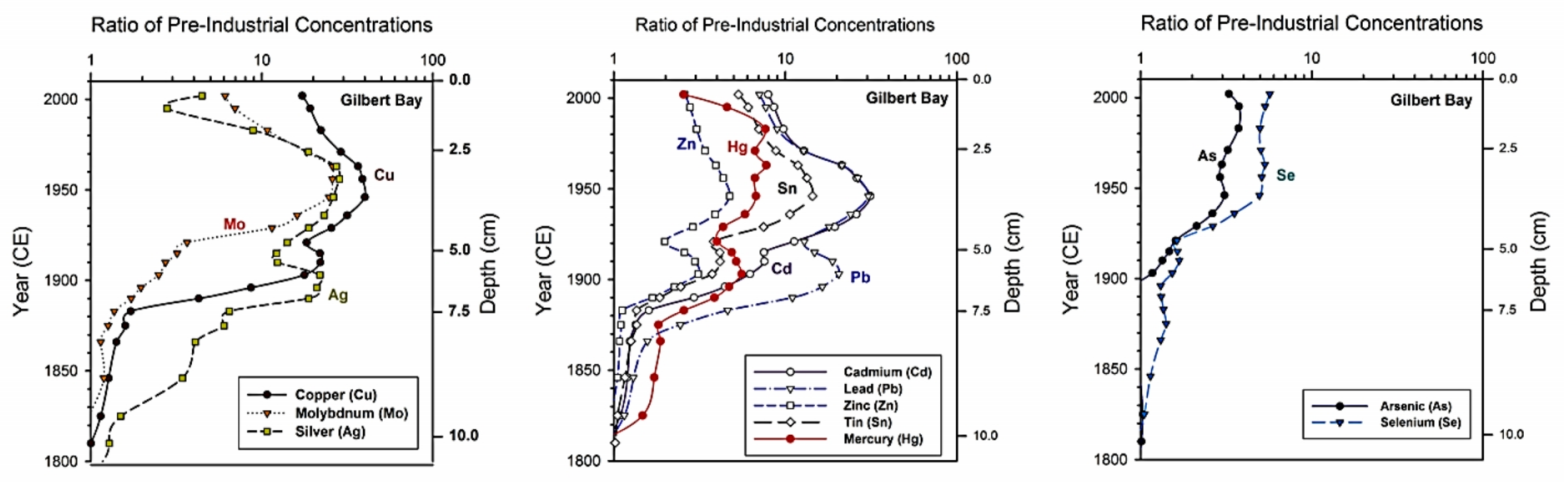

Figure 10. Contamination indices of metal concentrations at each depth in a Gilbert Bay core (Site 4) relative to mean concentrations prior to 1860. A ratio of 1 indicates background, uncontaminated conditions. A. Metals derived primary from porphyry copper and sedimentary rock-hosted gold and silver deposits in the Bingham Canyon and Mercur mining districts of Utah. B. Ratio of metals derived from polymetallic replacement deposits in the Tintic, Park City and Bingham mining districts. C. Ratios for arsenic and selenium. Three-point running means are plotted to smooth the curves. Note log scales.

The maximum degree of pollution in the sediments can be characterized by calculating a Maximum Contamination Index which shows the maximum concentration observed throughout a core, relative to the mean pre-industrial background concentration (Fig. 11a). The two core sites in Gilbert Bay showed relatively similar patterns. Silver and copper in these cores showed the highest Maximum Contamination Indices, with values $>40$-fold above background. The indices for silver are somewhat problematic, as pre-industrial concentrations in some strata were below levels of detection, so we assumed that these were $80 \%$ of the detection level, and this influenced the resulting Contamination Indices. Lead, molybdenum and cadmium had intermediate Maximum Contamination Indices (16-34 fold above background). Mercury had a Maximum Contamination Index of 4 and 12 at Sites 3 and 4, respectively. Selenium, zinc and arsenic all had contamination indices $<6$. The Maximum Contamination Indices at Site 1 in Farmington Bay did not show the same trends as those in Gilbert Bay. In Farmington Bay mercury and silver were much more enriched relative to background concentrations with Maximum Contamination Indices above 50. Lead, tin, copper and cadmium in the Farmington Bay core had Maximum Contamination Indices of 12-23 which were generally lower than those in Gilbert Bay. 


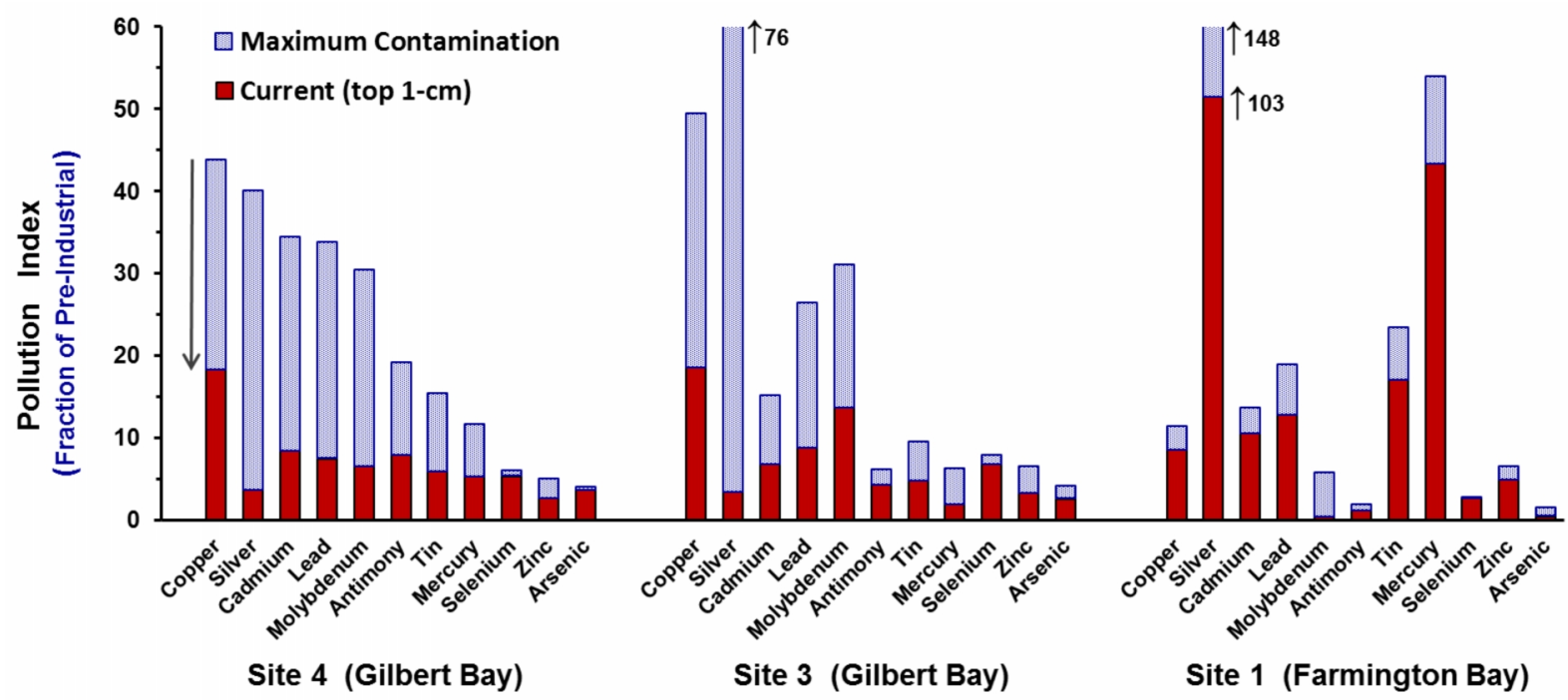

Figure 11. Maximum Contamination Index (maximum/background) in the sediment cores (blue) and the Current Contamination Index (surface concentration/background; red) for 11 metals and metalloids at three coring sites in the Great Salt Lake. These values are based on the actual maxima (not the 3-pt running means) that are shown in Figure 10. The down-arrow depicts how concentrations of many metals in Gilbert Bay are now considerably lower than during the highest contamination period in the 1950s and 1960s.

The present condition of surficial sediments can be summarized with the Current Contamination Index, or the amount of a metal in the top 1-cm of sediments expressed relative to background conditions (Fig. 11). When viewed in relation to the Maximum Contamination Index, the degree of improvement can be assessed. For Gilbert Bay the Current Index indicates that both selenium and arsenic are still near the highest levels observed in the cores, either because inputs are continuing, or because these two metalloids are more mobile in sediments than others. Copper and lead, which had some of the highest Contamination Indices, have recovered significantly, and concentrations in surface sediments are only 22$42 \%$ of the highest concentrations observed in the 1950s and 60s. Nevertheless, most metal concentrations in the surface sediments of Gilbert Bay are still 3-18 fold higher than background concentrations.

For the Farmington Bay core site, the Current Contamination Indices show that there has been relatively little decrease in the concentration of most metals (Fig. 11). The surface concentrations of arsenic and molybdenum are the only ones that have declined markedly since peak levels of contamination. In fact, the main reason that the other metals have Current Contamination Indices much below The Maximum Contamination Index is because of the short-lived spike in concentrations that occurred in the middle of the 1950s (Fig. 8). Following the recovery from that spike, most metal concentrations have maintained relatively similar or slightly increasing concentrations for the last 40 years, suggesting that metal pollution is continuing in this area of Farmington Bay (Fig. 8, Appendix 1). 
Table 3. Average concentrations $\left(\mu \mathrm{g} \mathrm{g}^{-1}\right)$ of metals in the top 1-cm of cores taken in three bays of the Great Salt Lake. Threshold effects concentrations (TEC) and the Probable Effects Concentrations (PEC) (McDonald et al. 2000) are also shown. For silver, the Washington State Standard (2002) for marine waters is shown as a TEC. For selenium the US Department of Interior (1998) values for "no effects" and "toxicity threshold" are used. Lake sediment concentrations exceeding the TECs are shown in bold numerals, and those exceeding the PECs are underlined. Note that these threshold and toxicity guidelines are shown only to provide comparison with criteria developed for fresh waters, and are not necessarily indicative of hazardous concentrations in Great Salt Lake sediments.

\begin{tabular}{|c|c|c|c|c|c|c|c|c|c|c|}
\hline \multirow[b]{2}{*}{ Metal } & \multirow[b]{2}{*}{ TEC } & \multirow[b]{2}{*}{ PEC } & \multicolumn{3}{|c|}{ Gilbert Bay } & \multicolumn{3}{|c|}{ Farmington Bay } & \multicolumn{2}{|c|}{ Bear River Bay } \\
\hline & & & 3 & 4 & 5 & 1 & 7 & 2 & 6 & 9 \\
\hline \multicolumn{11}{|c|}{ Metals exceeding freshwater threshold effect concentrations at one or more sites } \\
\hline Selenium & 1.0 & 4.0 & $\underline{4.5}$ & $\underline{4.9}$ & $\underline{4.3}$ & 2.4 & 2.1 & 3.6 & 1.2 & 0.8 \\
\hline Copper & 32 & 149 & 102 & $\underline{207}$ & 91 & 145 & 132 & 47 & 16.4 & 14.8 \\
\hline Arsenic & 10 & 33 & 23 & $\underline{47}$ & 18 & 19 & 21 & 14 & 7 & 5 \\
\hline Mercury & 0.18 & 1.06 & 0.11 & 0.42 & 0.30 & 0.88 & 0.66 & 0.20 & 0.05 & 0.05 \\
\hline Cadmium & 1.0 & 5.0 & 1.1 & 2.4 & 0.7 & 2.8 & 2.5 & 0.9 & 0.4 & 0.4 \\
\hline Lead & 36 & 128 & 31 & 58 & 21 & $\underline{130}$ & 83 & 29 & 19 & 15 \\
\hline Zinc & 121 & 459 & 75 & 125 & 47 & 264 & 205 & 76 & 46 & 35 \\
\hline \multicolumn{11}{|c|}{ Other Metals } \\
\hline Cobalt & & & 3 & 4 & 2 & 5 & 4 & 2 & 4 & 4 \\
\hline Chromium & 43.4 & 111.0 & 8.5 & 11.5 & 5.9 & 35.3 & 23.1 & 7.5 & 9.3 & 7.3 \\
\hline Molybdnum & & & 32.6 & 16.9 & 21.6 & 1.2 & 1.1 & 20.9 & 0.4 & 0.1 \\
\hline Nickel & 22.7 & 48.6 & 9.8 & 14.3 & 6.5 & 12.7 & 13.8 & 8.1 & 13.3 & 9.7 \\
\hline Antimony & & & 0.40 & 0.64 & 0.62 & 0.04 & 0.06 & 0.48 & 0.03 & 0.02 \\
\hline Silver & & & 0.02 & 0.1 & $<0.03$ & 1.9 & 2.0 & 0.1 & 0.1 & 0.1 \\
\hline Tin & & & 0.77 & 1.65 & 0.62 & 2.76 & 0.06 & 0.48 & 0.03 & 0.02 \\
\hline Titanium & & & 0.39 & 0.84 & 1.40 & 0.43 & 0.35 & 1.54 & 0.49 & 0.32 \\
\hline Vanadium & & & 13.7 & 19.7 & 9.7 & 21.8 & 20.6 & 11.4 & 9.6 & 8.3 \\
\hline
\end{tabular}

\section{Metal concentrations in surface sediments}

The surface sediment data indicate that both Gilbert and Farmington Bays have concentrations of several metals that are above Threshold Effects Criteria established for fresh waters, but that Bear River Bay is relatively uncontaminated (Table 3; Appendix 1). From a current ecosystem health perspective, the most relevant metal concentrations are those at the sediment-water interface, as they are the ones that most influence diffusion into the water column, and uptake by the benthic biota. Selenium exceeded the freshwater threshold effects criteria most frequently (Table 3). Concentrations of selenium were highest at all three sites in Gilbert Bay, and exceeded the freshwater Probable Effects Concentration at all of these. Selenium also exceeded the Threshold Effects Concentrations at all three sites in Farmington Bay, but never exceeded the PEC concentration. Selenium in the sediments in Bear River Bay only exceeded 
the TEC at one site. Copper and arsenic concentrations exceeded the TEC at all of the sites in Gilbert and Farmington Bays but never in Bear River Bay. Mercury was also relatively high in the surface sediments of Gilbert and Farmington Bay, but concentrations did not exceed the PEC level in any of them. Again, Bear River Bay had relatively low levels of this contaminant. Cadmium, lead and zinc had concentrations above TEC levels at one or more sites in Gilbert and Farmington Bays.

Coring sites closest to many pollutant sources at the south end of the lake usually had higher surface metal concentrations than those further from these putative sources (Fig. 12). In Gilbert Bay, Site 4 which is closest to smelters and industrial centers in the Salt Lake Valley had higher concentrations of nearly all the metals than did Sites 3 and 5. This was particularly true for copper. In Farmington Bay there was a consistent gradient for all of the metals that were above TEC concentrations, with Site 1 near the NW Oil Drain discharge and closer to smelters having the highest concentrations, followed by Site 7 which is also at the south end of the bay, and with the lowest concentrations at Site 2 at the northern end of the bay. Bear River Bay at the northern end of the lake had the lowest concentrations of all of the metals measured.

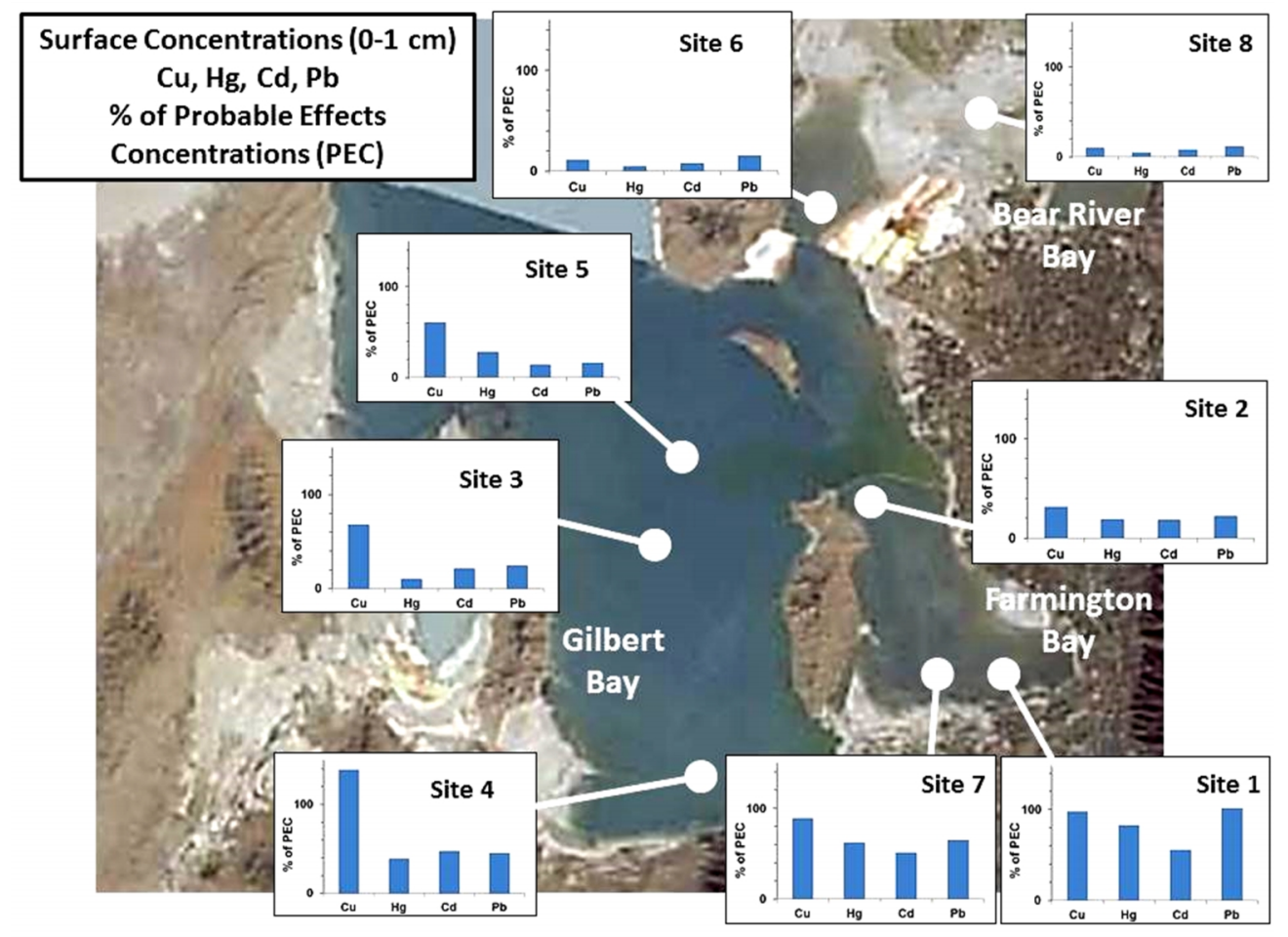

Figure 12. Mean surface $(0-1 \mathrm{~cm})$ concentrations of copper $(\mathrm{Cu})$, mercury $(\mathrm{Hg})$, cadmium $(\mathrm{Cd})$ and lead $(\mathrm{Pb})$ at eight sites in the Great Salt Lake expressed as a percentage of the probable effects concentrations (PEC) developed for freshwater organisms (Table 3; Macdonald et al. 2000). 


\section{Discussion}

Gilbert Bay chronologies - In Gilbert Bay the sediment chronologies for most metals showed 10-60 fold increases in concentrations in the early to mid-1900s, followed by significant declines in the latter half of the century. The increases of many of these metals in the lake paralleled the increases in production of these metals from smelters in the Salt Lake Valley and nearby mining districts. These processed metals originated not only from mines near the Great Salt Lake, but also from more distant areas; as the Salt Lake Valley was a smelting center for the intermountain west during the early and mid- $20^{\text {th }}$ century (Varley et al. 1921). The increases in metal contaminants in the sediments are consistent with those described in Uinta Mountain lakes, 90-155 km east of the Great Salt Lakes (Kada et al. 1994; Moser et al. 2010; Reynolds et al. 2010), thus suggesting that atmospheric deposition has been an important mechanism for the contamination of the Great Salt Lake sediments. The magnitude of increase in metals in the Great Salt Lake was much greater, however, than in the distant Uinta Lakes. For example, in Marshall and Mirror Lakes that are 90-110 km from the Great Salt Lake, increases in lead were 11-12X background, compared to increases of 21-34X at Sites 3 and 4 in the Great Salt Lake (Kada et al. 1994; Reynolds et al. 2010). The difference in copper deposition was even greater between the sites, with contamination factors of $\sim 2 \mathrm{X}$ in the two Uinta Lakes and $34 \mathrm{X}$ in the Great Salt Lake. Maximum contamination indices were even less at a Uinta lake $155 \mathrm{~km}$ east of the Salt Lake Valley (Reynolds et al. 2010). Consequently, the very high metal concentrations found in older Great Salt Lake sediments is not surprising given the lake's proximity to the smelting activities and other industrial activities in the Salt Lake Valley.

The decline in metal contamination in younger sediments in the Great Salt Lake is likely due to improvements in smelting techniques, and in some cases, to lower production of specific metals from the mines. In the case of lead and zinc, production in the State has dropped to zero, and this is reflected in the sediments with current concentrations of only $22-33 \%$ and ca. $45-53 \%$ of the peaks in the 1940 s and $50 \mathrm{~s}$, respectively. Additionally, lead use in gasoline peaked in the early 1970s and has also declined to near zero (Laws 1993) and this may have contributed to lower concentrations in recent sediments. In contrast to lead, copper production in Utah has continued to increase to record levels (Fig. 6), but copper levels in the sediments have nevertheless declined to $33-42 \%$ of the maximum levels found in the mid-1950s. The decline in copper and other metals in the sediments is likely due to improvements in technology and virtual halt of lead-zinc mining and smelting in the Great Basin in the early 1970s. Some of the improvements began as early as 1906 when farmers sued smelters in Midvale, Utah and forced them to reduce emissions of sulfuric acid, lead and zinc (http://utahrails.net/mining/smelters-midvale.php). The smelters responded by processing ores with less sulfur, and by building a higher smoke stack to help disperse the pollutants from the valley. Other improvements were initiated after the Clean Air Act of 1963 and subsequent amendments in the 1970s. Economic factors also helped reduce emissions, because smelters began to recover the sulfuric acid that carries the metals, and sell it for a profit. As a result of emission controls and economic factors, one of the largest copper producers in the world (Kennecott Copper, now Rio Tinto) located on the south shore of the Great Salt Lake, reduced emissions of sulfuric acid from $\sim 22 \mathrm{MT} \mathrm{h}^{-1}$ in 1974 to $\sim 0.03 \mathrm{MT} \mathrm{h}^{-1}$ (Newman et al. No Date).

Another mechanism that could have contributed to the decline of metals in the sediments involves the construction of the Southern Pacific railroad causeway that divided the lake in half and led to the formation of a deep brine layer (monimolimnion) in Gilbert Bay (Gwynn 2002a; Jones and Wurtsbaugh 
2014). This dense brine layer is frequently present below a depth of $\sim 6.5 \mathrm{~m}$, and the density of the deeper brine reaches $1.2 \mathrm{~g} \mathrm{~cm}^{-3}$, which is higher than that of most algal and detrital particles (Crosman and Horel 2009). Since most metals normally reach lake sediments as part of the algal and detrital sedimentation process, the presence of the deep brine layer may retain some of this material above the sediments, where mineralization would release it to the dissolved form. The deep brine layer contains extremely high concentrations of particulate organic carbon, as well as very high concentrations of dissolved mercury (Tank and Dodds 2003; Jones and Wurtsbaugh 2014), yielding some support for this hypothesis. Wurtsbaugh and Jones (Jones and Wurtsbaugh 2014) estimated that about 40\% of the deep brine water may be entrained into the upper mixed layer each year, which could also keep metals from accumulating in the sediments. Cores taken by Reynolds and Moser (2010) in the Uinta Mountain lakes east of smelting activities did not record decreases in copper comparable to what we found in the Great Salt Lake. Additionally, most metals began to decline in the sediments of the Great Salt Lake at estimated dates of approximately 1950 (Site 4; Fig. 10), before the advent of much cleaner smelting technologies, and close to the time of construction of the railway causeway in 1959. These observations provide some support for the hypothesis that the deep brine layer may play a role in reducing metal accumulation in the sediments. However, more research will be necessary to determine the validity and importance of this hypothesized mechanism.

Like many of the other metals, mercury concentrations in the sediments of Gilbert Bay are also declining from the highest levels observed in the first part of the $20^{\text {th }}$ century, although the record of decline at Site 4 has been erratic. Atmospheric and riverine deposition of mercury in the Great Salt Lake is continuing and may be enhanced by gold mining activities in Nevada and Utah, in addition to emissions from coal-burning power plants in central Utah and worldwide (Naftz et al. 2009a). However, the atmospheric and riverine input to the lake is not abnormally high compared to other western areas of the United States (Smith 2003; Peterson and Gustin 2008), nor has it been suggested that deposition rates are decreasing. The overall decline of mercury concentrations in the sediments suggests that the high mercury levels found in the lake (Naftz et al. 2008) may be due at least partially to legacy effects of early mining activities. Naftz et al. (2008) also found decreasing mercury concentrations in the surface strata of a core collected in Gilbert Bay that were comparable to the declines measured at Sites 3 and 4, suggesting that this may be a general phenomenon, at least for the deep areas of the lake.

The reason for the slightly higher and more irregular pattern of mercury and other metal concentrations in the Gilbert Bay Site 4 core than in the Site 3 core is not clear. One possible explanation is that periodic releases of sediments from the Kennecott/Rio Tinto south tailings pond near the south shore of the lake have contributed irregularly to the metals loading, and thus caused peaks in concentration. Site 4 is located at the south end of the lake $\sim 13 \mathrm{~km}$ from the tailings pond whereas Site 3 is located $37 \mathrm{~km}$ to the north. The tailings pond dikes failed in 1941-42, 1944, 1951, 1964 and in 1969, although it is not clear how much material from the pond made it to the Great Salt Lake (EPA 2002). Additionally, in 1965 Kennecott experimented with waste disposal by building a south-shore dike that contained $56,000 \mathrm{~m}^{3}\left(2\right.$ million $\left.\mathrm{ft}^{3}\right)$ of tailings material. The dike was destroyed by wave action within two years, and the materials dispersed into the lake (EPA 2002). Typical tailings materials at the site contain $30 \mu \mathrm{g} \mathrm{g}^{-1}$ arsenic, $240 \mu \mathrm{g} \mathrm{g}^{-1}$ lead and $6 \mu \mathrm{g} \mathrm{g}^{-1}$ selenium. If this material was spread over just $25 \%$ of the southern area of Gilbert Bay, it would have only deposited a layer about $0.8 \mathrm{~mm}$ thick and thus could have had some impact on concentrations. Dust blowing from the tailings ponds (EPA 2002) could 
also contribute some metals to the southern end of the lake (particularly $\mathrm{As}$, $\mathrm{Se}$, and $\mathrm{Pb}$ ), but the impact of this is unknown.

In contrast to most metals, selenium and arsenic concentrations in more recent sediments are either stable or showing slight increases. Arsenic occurs in both the Mercur gold ores and lead-zinc ores of western Utah. Selenium occurs at low, but geochemically anomalous levels in the Bingham Canyon porphyry copper deposits and is released from smelting activity (Newman et al. No Date). Selenium is also released in the Bear River watershed that drains phosphate mining districts in Idaho and the Uinta Mountains (Mars and Crowley 2003, Hamilton and Buhl 2005). Strip mining of phosphate has increased in recent years (Hughes and Thackray 1999) and thus contributions from this source may be increasing. However, Naftz et al. (2009b) found that only $25 \%$ of the riverine selenium loading was from the Bear River, and $75 \%$ were from the Salt Lake Valley watershed, particularly sub-drainages and outfalls associated with the Kennecott Mine tailings ponds. Arsenic and selenium are also emitted from smelting activities, as demonstrated locally by accumulations in Uinta Mountain lakes (Moser et al. 2010; Reynolds et al. 2010), and from tailings wastewater (EPA 2002). Consequently, the mining-related activities in the Great Salt Lake region may be the predominant source of this contamination.

Farmington Bay metal chronologies - The sediment core taken from the south end of Farmington Bay also showed significant levels of metal contamination, but the chronology is very different from that in Gilbert Bay (Fig. 13A), and not consistent with known periods when contaminants were entering the lake. The chronologies shown in Fig. 8 imply that there was little or no contamination with toxic metals in Farmington Bay from the late 1800 s until the late 1950 s or early 1960 s, and then concentrations for most metals rose suddenly to high levels. However, the Gilbert Bay cores and the studies in the Uinta Mountains (Kada et al. 1994; Moser et al. 2010; Reynolds et al. 2010) indicate that atmospheric deposition of metals was widespread from the Salt Lake Valley smelting activities in the early 1900s, so it seems improbable that Farmington Bay escaped this contamination. Additionally, the Jordan River also
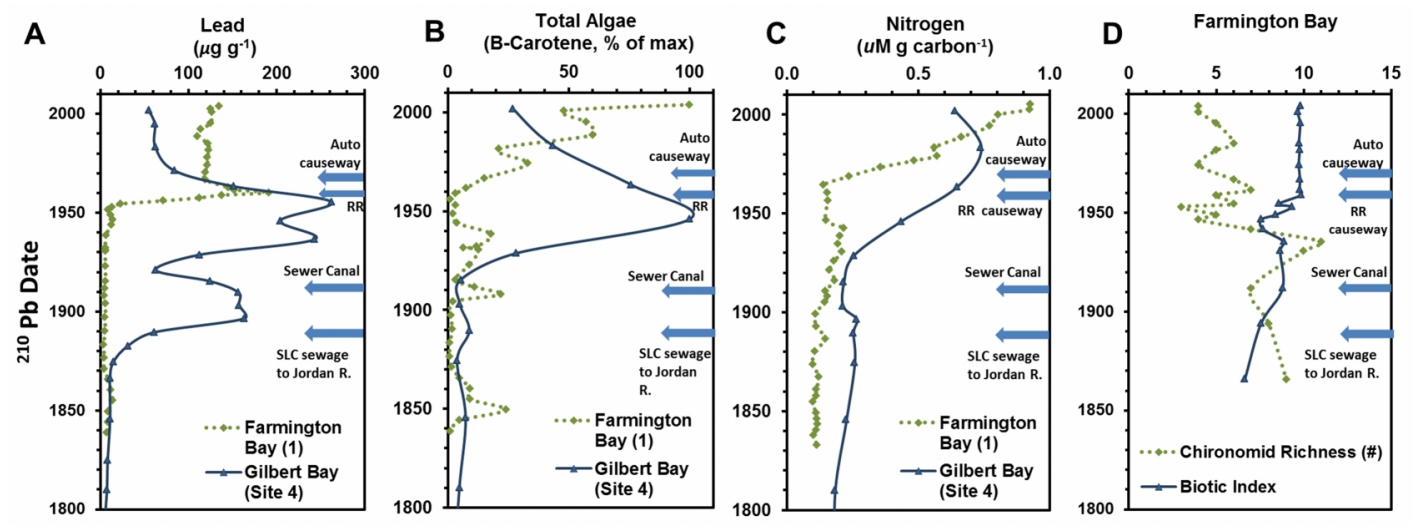

Figure 13. A-C. Comparisons of lead, a total algal pigment indicator and nitrogen content of the sediments in the Farmington Bay core, and in Site 4 in Gilbert Bay. D. Changes in chironomid species richness and a biotic index in Farmington Bay (from Moser et al. 2012). For the biotic index (D), the earliest estimate (1841) was not plotted because only 1 chironomid head capsule was found. Arrows show the timing of important events increasing pollution to Farmington Bay, and in changing the hydrological connectivity between different parts of the lake. 
discharges near Site 1, and was contaminated with lead and arsenic by sludge from the Murray Smelter that operated from 1872 until 1949 (and is now a Superfund Site; (Keck and Lepori 2012). Furthermore, the Northwest Oil Drain that joins the Sewer Canal and discharges 1-2 km from the coring site has been "used to convey urban stormwater flows, industrial stormwater discharges and wastewater effluent discharges" since its construction in 1922. The canal is currently an EPA Superfund Cleanup Site and lead, copper and arsenic are metals of concern (The Forrester Group 2001). The Sewer Canal also connects to the City Canal which drained industrial areas of much of central Salt Lake City. Discharges into the Oil Drain did likely increase in the late 1940s and 50s when refinery expansion occurred (Strack 2009), but this cannot explain the lack of metals in the core that should have been deposited from atmospheric contamination occurring from the late 1800 s through the entire $20^{\text {th }}$ century. Redox, $\mathrm{pH}$ and organic matter accumulation can influence the mobility and thus the accumulation of metals in sediments (Boudreau 1999). However, Farmington Bay was reportedly highly organic since the diversion of raw sewage into the south end of the bay starting in 1911 (Van Der Meide and Nicholes 1972), so metals likely had binding sites. The automobile causeways to Antelope Island constructed in 1952 and 1969 may have contributed to metal increases in the sediments by reducing advection to Gilbert Bay, and increasing algal growth (Healey and Hendzel 1980). Additionally, the diversion of flood flows to Gilbert Bay via the Goggin Drain that began in 1952 may have reduced flushing of Farmington Bay with relatively high quality snow-melt water. Measurements of a core from Site 1 indicated that total carbon in the sediments rose gradually from 5-6\% from 1840-1950, and then more rapidly from $6-9 \%$ during the 1950-2000 period (P. Leavitt, unpublished data). This suggests that perhaps there was more organic carbon after 1950 that could have increased metal retention, but the differences over the length of the core are not large. Additionally, metals are relatively immobile in alkaline environments (Dillon et al. 1988; Belzile et al. 2004) such as those in the Great Salt Lake, especially when sulfates and $\mathrm{H}_{2} \mathrm{~S}$ production are high and metal sulfides are precipitated (Carignan and Nriagu 2003). Naftz et al. (2000) analyzed a sediment core from the south end of Farmington Bay and found that lead and other pollutants increased significantly between 1916 and 1950, but the depth resolution of their analysis was insufficient to help resolve the discrepancy in my core between the ${ }^{210} \mathrm{~Pb}$ dating and known pollution activities. An additional core they took in Decker Lake, located near Farmington Bay and in the floodplain of the Jordan River yielded no interpretable ${ }^{210} \mathrm{~Pb}$ dating (Naftz et al. 2000; Naftz, personal communication. The reason that the Farmington Bay core showed no indication of metal contamination up until the 1950's is thus unclear, but it is not likely that the sediments accurately recorded the metals in the bay during this period.

The sudden increase of metals in Farmington Bay in the 1950s and early 1960s parallels similar increases in most eutrophication metrics (e.g. pigments, nitrogen, isotope signatures, diatoms, etc.; (Healey and Hendzel 1980) and macroinvertebrate bioindicators (Dodds et al. 2002). For example, the ${ }^{210} \mathrm{~Pb}$ chronology indicates that the metric of total algal pigments (B-carotene) and nitrogen content in Farmington Bay did not increase significantly above the 1850s-1950s baseline until after 1960, whereas the increases began much earlier in Gilbert Bay (Figs. 13b, c). There were some changes in Farmington Bay prior to. 1960 in purple sulfur bacteria, the cyanobacteria Gleotrichia sp. and chlorophyte fossils (Healey and Hendzel 1980), but the majority of eutrophication parameters did not respond until after this date. Similarly, the benthic invertebrates in Farmington Bay had only minor responses until after $\sim 1950$ (Fig. 13d). These delayed responses are not consistent with the changes in Gilbert Bay that started in the earlier part of the century because: (1) most nutrients and organic pollution first enter Farmington Bay a few kilometers from Site 1 before being advected into Gilbert Bay, and; (2) dilution of nutrients in Gilbert 
Bay would have been 100-fold greater than in Farmington Bay prior to the Railway Causeway construction, and 50-fold after the construction. Nutrient and organic pollution of Farmington Bay (and the rest of lake) would have begun with the early sewage discharges into the Jordan River in 1889, but would likely have increased markedly in 1911 when the Sewer Canal was constructed to the south end of Farmington Bay (Hooton no date). Vander Meide and Nicholes (1972) described the pollution situation there as: "...until recently, the entire liquid sewage refuse of the Wasatch Front towns ... ended up untreated, except for dilution, in the estuary. This practice has resulted in a sewage delta of rather large proportions in a very localized area." Consequently, it seems that for many of the eutrophication indicators, like the metals, the sediments did not retain an accurate record of eutrophication in the early part of the $20^{\text {th }}$ century. Reduced hydrologic flushing due to the construction of the Antelope Island causeways likely exacerbated an already bad situation by retaining nutrients and by freshening Farmington Bay and consequently allowing the growth of nitrogen fixing cyanobacteria. This, in turn, may have increased nitrogen export to Gilbert Bay.

Regardless of difficulties in interpreting the timing of the older sediment record of metals in Farmington Bay, the recent pattern is clear: Concentrations of all metals are high and showing no indication of decreasing (Fig. 8). This contrasts with the substantial declines in the concentrations of most metals in the more recent sediments Gilbert Bay. The stability of the metal concentrations in the Farmington Bay core suggests that loading via the Northwest Oil Drain/Sewer Canal or some other source may still be contributing to the high levels of many metals that are now higher than those found in the Gilbert Bay cores. Additionally, the smearing of the ${ }^{137}$ Cesium (Fig. 5) suggests that some sediment mixing, or mobility of metals within the sediments could be occurring at this site, and this would also minimize decreases of metals in the surficial sediments.

Spatial distribution and toxicity of metals-Concentrations of metals in the surface sediments varied widely in the three bays, with those at the south end of Farmington Bay being the highest, and those in Bear River Bay the lowest. These results can be compared with studies done on sediments in 1986 (Sorensen et al. 1988) when the lake was near its all-time high elevation and a recent study (Waddell et al. 2009) when the lake was low. Sorensen et al. (1988) sampled sediments in a grid pattern in the vicinity of the Sewer Canal outfall that included our Site 1 location (Fig. 14), and found mean levels in surficial sediments that were within $20 \%$ of the values we found (Table 3). However, $5 \mathrm{~km} \mathrm{NW}$ of Site 1 they found concentrations of most metals that were $<20 \%$ of the highest concentrations found near the outfall (Fig. 14), thus indicating that our Site 1 may represent a worst-case scenario for metals contamination in Farmington Bay. Waddell et al. (2009) found concentrations near the Sewer Canal outfall that were approximately $50 \%$ of what we measured, but Sorensen et al's study demonstrated that there are finescale pockets of contamination associated with oil and grease deposits, so the difference between the studies is not surprising.

Our samples in Bear River Bay generally had relatively low concentrations of metals (Table 3), with only selenium exceeding threshold effects concentrations. Given the heavy mining activity and selenium contamination in the Bear River drainage, this is surprising. However, selenium only exceeded the Threshold Effects Concentration at one of the two sites, and only by a small amount, so the situation does not appear to be severe. The metal concentrations in Bear River Bay may also be low because of the high sediment load carried by the river (Allred and Judd 2002) that should "dilute" metals entering the system. Sorensen et al. (1988) also sampled sediments where Bear River Bay connects with Gilbert Bay 
(Lucin Cutoff), and generally found metal concentrations 2-4 times higher than we encountered at the two sites within Bear River Bay itself. The reason for the difference is not clear, but their sampling site was near the railway line, and thus might have had local contamination from the locomotives.

In Gilbert Bay's surface sediments we found that most metals exceeded the Threshold Effects Concentrations, and copper, arsenic and mercury exceeded Probable Effects Concentrations. However, these concentrations were found in deep area of the lake under the deep brine layer (monimolimnion) where there are no macroinvertebrates due to the anoxic, reducing conditions there (Collins 1980; Bioeconomics 2012). The movement of the metals beneath the deep brine layer into strata that might influence

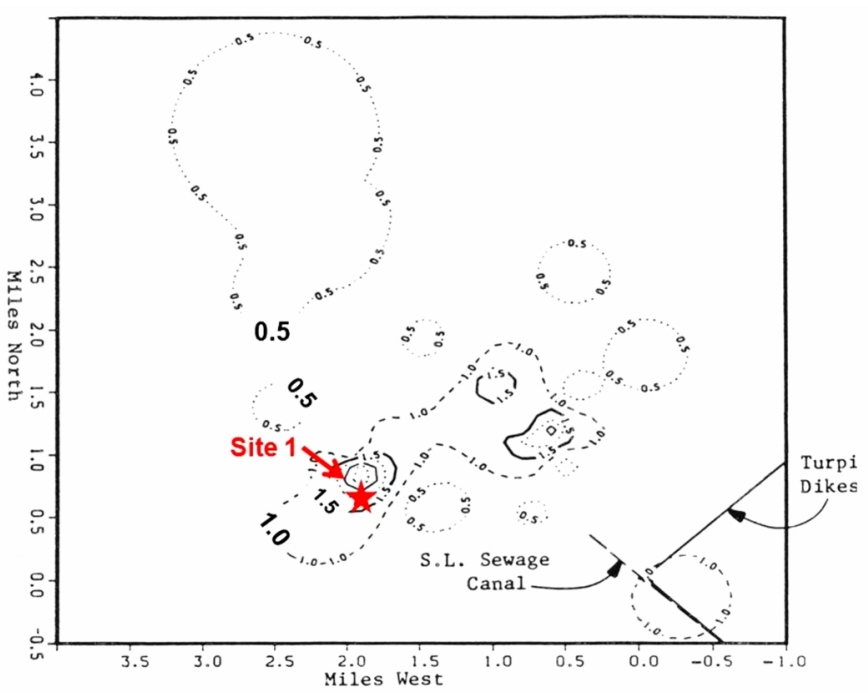

Figure 14. Isopleths of total mercury concentration $\left(\mu \mathrm{g} \mathrm{g}^{-1}\right)$ near the outlet of the Salt Lake City Sewage Canal (NW Oil Drain) described by Sorensen et al. (1988). The location of our Site 1 is shown with a red star, and demonstrates that our core was located in a hot-spot of mercury contamination (and other metals). the food web in the mixed layer may be dependent on internal waves (seiches) that can suspend sediments at the periphery where this layer contacts the bottom sediments (Beisner et al. 2009). Additionally, when the lake reaches very low elevations, the deep brine layer can disappear and this might allow colonization by brine fly larvae, thus exposing them to the metals in the deep sediments. An additional factor that we cannot assess with our limited coring is the vertical distribution of metals in the sediments in shallower water. These sediments might be more vulnerable to turbulence that could homogenize the upper layers, thus providing higher concentrations of most of the metals to benthic invertebrates and brine shrimp that sometimes graze at the sediment-water interface. Consequently, although we noted marked decreases in the concentrations of most metals in the surficial sediments, these decreasing profiles are not necessarily representative of sediments in shallow areas of the lake where macroinvertebrates feed. However, Waddell et al. (2009) did not find marked differences in metals concentrations between samples collected at deep offshore sites, and those in shallower water. Their sampling, however, was with a Ponar dredge that penetrated ca. 3-7 $\mathrm{cm}$ into the sediments (N. Darnall, personal communication), and thus would have provided a sample that averaged metal concentrations that may have varied several fold. In some cases a sample that averaged several decades of deposition would be desirable, but if the more active surface layer is the target of an investigation, care should be taken to standardize the thickness of the sediments that are sampled. Nevertheless, the metal concentrations measured by Waddell et al. (2009) were generally similar to our surface samples, thus suggesting that their concentrations were representative of the metal concentrations that the biota would be exposed to.

The primary invertebrates in Gilbert Bay that would be exposed to the metals in the sediment are brine flies which are relatively resistant to toxins (Brix et al. 2004). Consequently, the fact that many 
metals in Gilbert Bay sediments exceed Threshold- and Probable Effects Concentrations for fresh water organisms is not necessarily a direct concern for this species. A bigger issue is whether brine flies bioaccumulate metals and transfer them into the birds that rely on them to fuel their migrations. Analyses of selenium and mercury bioaccumulation in the brine flies living on stromatolites in the lake have not shown significant biomagnification in the lower food chain (Wurtsbaugh 2009; Wurtsbaugh et al. 2011). However, stromatolite and benthic sediment communities may function quite differently, so care must be applied to extending this earlier work to all of the lake community. The south end of Farmington Bay has a much wider diversity of invertebrates (Dodds et al. 2002) that are adapted to fresh water, and the high concentrations of metals in those sediments could potentially impact them if the freshwater Threshold Effects Concentrations and Probable Effects Concentrations are exceeded. However, since the spatial extent of sediments in Farmington Bay with high metal concentrations is limited (Fig. 12; Sorensen et al. 1988) the effects may be localized.

\section{Conclusions}

The Great Salt Lake, located next to a major mining, smelting and industrial area, has been very contaminated with a variety of metals. Despite the very high metal concentrations in sediments deposited in mid-1950s, most metal concentrations in more recent deposits have declined substantially, likely as a result of: (1) decreased mining for some minerals such as lead and zinc; (2) cleaner smelting technologies; (3) removal of lead from automotive gasoline, and (4) other environmental controls. The formation of the deep brine layer starting in 1969 also likely has reduced toxic metal delivery to the sediments. Although there have been marked decreases in metal concentrations, levels of copper, mercury, cadmium, lead, zinc, selenium and arsenic remain above freshwater Threshold Effects Concentrations at one or more stations in Gilbert and Farmington Bays. Bear River Bay, although not sampled extensively, does not appear to have a metals contamination problem. The invertebrates in the high-salinity areas of the Great Salt Lake may be relatively resistant to a variety of pollutants and the freshwater criteria consequently may not be applicable for them. Nevertheless, these invertebrates can be vectors that transfer metals to birds that depend on this ecosystem. Additional research will be needed to determine if some of the poorly-studied metals in the lake $(\mathrm{Cu}, \mathrm{As}, \mathrm{Cd}, \mathrm{Pb}$ and $\mathrm{Zn})$ might be having adverse effects on the bird community. Notwithstanding the declining levels of many metals in the lake, concentrations of arsenic and selenium are either stable or increasing in the sediments. Managers should carefully monitor these metals to insure that they do not increase to even higher levels.

\section{Acknowledgements}

Michelle Kang, Erin Fleming Jones, Ryan Choi, Dave Powelson, Zoraida Quinones-Rivera, David Barnes, Katie Fisher, David Epstein, Jeremy Mears provided field and laboratory assistance. Jodi Gardberg and Jeff Ostermiller provided assistance in the field and were particularly helpful in coordinating many aspects of the study and report preparation. Kenneth Krahulec and Elizabeth Palmer provided insights on mining and ore processing history in Utah and Idaho. Peter Leavitt and Katrina Moser collaborated in the design of the study and assisted in field and laboratory analyses. Peter Leavitt was responsible for the dating of the cores. Joan McLean, William Johnson, Tammy Rittenour and an anonymous reviewer provided valuable advice on metal mobility in sediments and core dating procedures. Bruce Waddell and Nathan Darnall provided information on contaminants in the Great Salt 
Lake. David Naftz provided raw data and insights on contaminants from earlier cores taken in Farmington Bay and nearby Decker Lake. Wally Gwynn provided historical information on contaminants in the lake. Funding for the work was provided by the Utah Division of Water Quality.

\section{References}

Aldrich, T. W., and D. S. Paul. 2002. Avian ecology of Great Salt Lake, p. 343-374. In J. W. Gwynn [ed.], Great Salt Lake: An overview of change. Utah Department of Natural Resources.

Allred, M. D., and H. L. Judd. 2002. Lower Bear River watershed restoration action strategy: A subbasin assessment for the Lower Bear River and Tributaries from GSL to Cutler reservoir in Box Elder County, Utah, p. 28. In D. o. W. Q. Utah Department of Environmental Quality [ed.]. Utah Department of Environmental Quality.

Appleby, P. G., and F. Oldfield. 1983. The assessment of Pb-210 data from sites with varying sediment accumulation rates. Hydrobiologia 103: 29-35.

Baskin, R. L. 2005. Calculation of area and volume for the south part of Great Salt Lake, Utah. OpenFile Report 2005-1327. United States Geological Survey.

Behrens, P. 1980. Industrial processing of Great Salt Lake brines by Great Salt Lake Minerals and Chemicals Corporation, p. 223-228. In J. W. Gwynn [ed.], Great Salt Lake: A scientific, historical and economic overview. Utah Department of Natural Resources.

Beisner, K., D. L. Naftz, W. P. Johnson, and X. Diaz. 2009. Selenium and trace element mobility affected by periodic displacement of stratification in the Great Salt Lake, Utah. Science of the Total Environment 407: 5263-5273.

Belzile, N., Y. W. Chen, J. M. Gunn, and S. S. Dixit. 2004. Sediment trace metal profiles in lakes of Killarney Park, Canada: from regional to continental influence. Environmental Pollution 130: 239-248.

Bioeconomics, I. 2012. Economic significance of the Great Salt Lake to the State of Utah. Great Salt Lake Advisory Council, Salt Lake City, Utah. Available online at: http://www.gslcouncil.utah.gov/docs/2012/Jan/GSL_Final_Report-1-26-12.pdf.

Boudreau, B. P. 1999. Metals and models: Diagenetic modeling in freshwater lacustrine sediments. Journal of Paleolimnology 22: 227-251.

Brix, K. V., D. K. Deforest, R. D. Cardwell, and W. J. Adams. 2004. Derivation of a chronic site-specific water quality standard for selenium in the Great Salt Lake, Utah, USA. Environmental Toxicology and Chemistry 23: 606-612.

Brix, K. V., R. M. Gerdes, W. J. Adams, and M. Grosell. 2006. Effects of copper, cadmium, and zinc on the hatching success of brine shrimp (Artemia franciscana). Archives of Environmental Contamination and Toxicology 51: 580-583.

Carignan, R., and J. O. Nriagu. 2003. Trace metal deposition and mobility in the sediments of two lakes near Sudbury, Ontario. Geochimica et Cosmochimica Acta 49: 1753-1764.

Cavitt, J. F. 2007. Concentration and effects of selenium on shorebirds at Great Salt Lake, Utah, p. 1-30. In U. D. o. W. Quality [ed.]. Utah Division of Water Quality.

Cline, C., J. Neill, J. Whitehead, and J. Gardberg. In prep. Mercury concentrations in Cinnamon Teal (Anas cyanoptera) and Northern Shoveler (Anas clypeata) at Great Salt Lake, Utah. In J. Gardberg [ed.], Ecosystem assessment of Mercury in Great Salt Lake, Utah, 2008. U.S. Geological Survey, Department of Interior.

Collins, N. 1980. Population ecology of Ephydra cinerea Jones (Diptera, Ephydridae), the only benthic metazoan of the Great Salt Lake, USA, USA. Hydrobiologia 68: 99-112.

Crosman, E. T., and J. D. Horel. 2009. MODIS-derived surface temperature of the Great Salt Lake. Remote Sens. Environ. 113: 73-81. 
Deseret News. 1952. Goggin drain ready to carry run off, p. 6B. Deseret News, 9 April 1952, Salt Lake City, Utah.

Dillon, P. J., H. E. Evans, and P. J. Scholer. 1988. the effects of acidification on metal budgets of lakes and catchments. Biogeochemistry 5: 201.

Dodds, W. K. and others 2002. N uptake as a function of concentration in streams. Journal of the North American Benthological Society 21: 206-220.

Ege, C. L. 2005. Selected mining districts of Utah. Utah Geological Survey.

Ellis, M. T. 1986. Acid deposition in Utah: An analysis by the Acid Deposition Technical Advisory Committee, p. 113. In U. B. o. A. Quality [ed.]. Bureau of Air Quality.

EPA. 2002. EPA Superfund record of decision: Kennecott (North Zone and South Zone). U.S. Environmental Protection Agency, Region 8. 265 p. Denver.

EPA. 2010. Guidance for implementing the January 2001 methylmercury water quality criterion. United States Environmental Protection Agency. Available online at: http://water.epa.gov/scitech/swguidance/standards/criteria/aqlife/methylmercury/upload/mercury2 010.pdf.

Felix, E. A., and S. R. Rushforth. 1979. The algal flora of the Great Salt Lake, Utah, U.S.A. . Nova Hedwigia 31: 163-195.

Gast, R. J., D. M. Moran, M. R. Dennett, W. A. Wurtsbaugh, and L. A. Amaral-Zettler. 2011. Amoebae and Legionella pneumophila in saline environments. Journal of Water and Health 9: 37-52.

Glew, J. R., J. P. Smol, and W. M. Last. 2001. Sediment core collection and extrustion, p. 73-106. In W. M. Last and J. P. Smol [eds.], Tracking environmental change using lake sediments volume 1: Basin analysis, coring, and chronological techniques. Kluwer.

Gwynn, J. W. 2002a. Great Salt Lake, Utah: Chemical and physical variations of the brine and effects of the SPRR Causeway, 1966-1996, p. 87-106. In J. W. Gwynn [ed.], Great Salt Lake: An overview of change. Utah Department of Natural Resources.

Gwynn, J. W. 2002b. The waters surrounding Antelope Island Great Salt Lake, Utah, p. 107-120. In J. W. Gwynn [ed.], Great Salt Lake: Overview of Change. Utah Department of Natural Resources.

Hamilton, S. J., and K. J. Buhl. 2005. Selenium in the Blackfoot, Salt, and Bear River watersheds. Environmental Monitoring and Assessment 104: 309-339.

Hayes, C. R. 1971. Distribution, populations, and species diversity of phytoplankton and zooplankton of Farmington Bay p. E2-E21. In C. K. Carter [ed.], Some ecological considerations of Farmington Bay estuary and adjacent Great Salt Lake State Park. University of Utah Library.

Healey, F. P., and L. L. Hendzel. 1980. Physiological indicators of nutrient deficiency in lake phytoplankton. Can. J. Fish. Aquat. Sci. 37: 442-453.

Hokanson, L. 1980. Ecological risk index for aquatic pollution control, a sedimentological approach. Water Research 14: 975-1001.

Hooton, L. no date. Salt Lake City Wastewater Collection and Treatment Program 1889 - 2000. Salt Lake City.

Hughes, S. S., and G. D. Thackray [eds.]. 1999. Guidebook to the geology of eastern Idaho. Idaho Museum of Natural History.

Jehl, J. R., W. S. Boyd, D. S. Paul, and D. W. Anderson. 2002. Massive collapse and rapid rebound: Population dynamics of eared grebes (Podiceps nigricollis) during an ENSO event. Auk 119: 1162-1166.

Jones, B. F., D. L. Naftz, R. J. Spencer, and C. G. Oviatt. 2009. Geochemical evolution of Great Salt Lake, Utah, USA. Aquatic Geochemistry 15: 95-121.

Jones, E. F., and W. A. Wurtsbaugh. 2014. The Great Salt Lake's monimolimnion and its importance for mercury bioaccumulation in brine shrimp (Artemia franciscana). Limnol. Oceanogr. 59: 141-155.

Kada, J., M. Heit, and K. M. Miller. 1994. Chronology of anthropogenic trace-element input to 4 Utah lakes reconstructed using sediment cores. Water Air Soil Pollut. 75: 353-369.

Keck, F., and F. Lepori. 2012. Can we predict nutrient limitation in streams and rivers? Freshwater Biology 57: 1410-1421. 
Lamborn, J. E., and C. S. Peterson. 1985. The substance of the land: agriculture vs. industry in the smelter cases of 1904 and 1906. Utah Historical Quarterly 53: 308-325.

Laws, E. A. 1993. Aquatic pollution: An introductory text. John Wiley and Sons.

Macdonald, D. D., C. G. Ingersoll, and T. A. Berger. 2000. Development and evaluation of consensusbased sediment quality guidelines for freshwater ecosystems. Archives of Environmental Contamination and Toxicology 39: 20-31.

Marcarelli, A. M., and W. Wurtsbaugh [eds.]. 2005. Ecological analyses of nutrients, plankton and benthic communities in Farmington Bay and the Great Salt Lake, Utah (2004). College of Natural Resources, Utah State University.

Marcarelli, A. M., W. A. Wurtsbaugh, and O. Griset. 2006. Salinity controls phytoplankton response to nutrient enrichment in the Great Salt Lake, Utah, USA. Canadian Journal of Fisheries and Aquatic Sciences 63: 2236-2248.

Mars, J. C., and J. K. Crowley. 2003. Mapping mine wastes and analyzing areas affected by selenium-rich water runoff in southeast Idaho using AVIRIS imagery and digital elevation data. Remote Sensing of Environment 84: 422-436.

Mcphee, W. M. 1977. The trail of the leprechaun. Exposition Press.

Moore, J. N., S. N. Luoma, and D. Peters. 1991. Downstream effects of mine effluent on an intermontane riparian system. Canadian Journal of Fisheries and Aquatic Sciences 48: 222-232.

Moser, K. A., J. S. Mordecai, R. L. Reynolds, J. G. Rosenbaum, and M. E. Ketterer. 2010. Diatom changes in two Uinta mountain lakes, Utah, USA: responses to anthropogenic and natural atmospheric inputs. Hydrobiologia 648: 91-108.

Naftz, D. and others 2008. Anthropogenic influences on the input and biogeochemical cycling of nutrients and mercury in Great Salt Lake, Utah, USA. Applied Geochemistry 23: 1731-1744.

Naftz, D., J. Cederberg, D. Krabbenhoft, K. Beisner, J. Whitehead, and J. Gardberg. In preparation. Mercury distribution in sediment and water samples collected from Great Salt Lake, Utah, and surrounding wetland areas. In J. Gardberg [ed.], Ecosystem assessment of Mercury in Great Salt Lake, Utah, 2008. U.S. Geological Survey, Department of Interior.

Naftz, D. and others 2009a. Mercury inputs to Great Salt Lake, Utah: reconnaissance-phase results, p. 37 49. In A. Oren, D. Naftz, P. Palacios and W. A. Wurtsbaugh [eds.], Saline Lakes Around the World: Unique Systems with Unique Values. Natural Resources and Environmental Issues. S.J. and Jessie Quinney Natural Resources Research Library.

Naftz, D., W. P. Johnson, M. L. Freeman, K. Beisner, X. Diaz, and V. A. Cross. 2009b. Estimation of selenium loads entering the south arm of the Great Salt Lake, Utah, from May 2006 through March 2008, p. 40. U.S. Geological Survey.

Naftz, D. L., D. W. Stephens, E. Callender, and P. C. Van Metre. 2000. Reconstructing historical changes in the environmental health of watersheds by using sediment cores from lakes and reservoirs in Salt Lake Valley, Utah, p. 6. In U. S. G. Survey [ed.]. National Water Quality Assessment Program. U.S. Geological Survey.

Newman, C. J., D. N. Collins, and A. J. Weddick. No Date. Recent operation and environmental control in the Kennecott Smelter. Kennecotte Utah Copper Corporation.

Nriagu, J. O. 1979. Global inventory of natural and anthropogenic emissions of trace-metals to the atmosphere. Nature 279: 409-411.

Nriagu, J. O., H. K. T. Wong, and R. D. Coker. 1982. Deposition and chemistry of pollutant metals in lakes around the smelters at Sudbury, Ontario. Environmental Science \& Technology 16: 551560.

Parnell, J. J., G. Rompato, T. A. Crowl, B. C. Weimer, and M. E. Pfrender. 2011. Phylogenetic distance in Great Salt Lake microbial communities. Aquatic Microbial Ecology 64: 267-273.

Peterson, C., and M. Gustin. 2008. Mercury in the air, water and biota at the Great Salt Lake (Utah, USA). Science of the Total Environment 405: 255-268. 
Pickhardt, P. C., C. L. Folt, C. Y. Chen, B. Klaue, and J. D. Blum. 2002. Algal blooms reduce the uptake of toxic methylmercury in freshwater food webs. Proceedings of the National Academy of Sciences of the United States of America 99: 4419-4423.

Plumlee, G. S., M. Montour, C. D. Taylor, A. R. Wallace, and D. P. Klein. 1996. Chapter 14. Polymetallic vein and replacement deposits. In E. A. du Bray [ed.], Preliminary compilation of descriptive geoenvironmental mineral deposit models. U.S. Geological Survey.

Post, F. J. 1981. Microbiology of the Great Salt Lake north arm. Hydrobiologia 81-2: 59-69.

Reynolds, R. L., J. S. Mordecai, J. G. Rosenbaum, M. E. Ketterer, M. K. Walsh, and K. A. Moser. 2010. Compositional changes in sediments of subalpine lakes, Uinta Mountains (Utah): evidence for the effects of human activity on atmospheric dust inputs. J. Paleolimnol. 44: 161-175.

Roberts, A. J. 2013. Avian diets in a saline ecosystem: Great Salt Lake, Utah, USA. Human-Wildlife Interactions 7: 149-159.

Schindler, D. W. 2012. The dilemma of controlling cultural eutrophication in lakes. Proceedings of the Royal Society B-Biological Sciences 279: 4322-4333.

Smith, V. H. 2003. Eutrophication of freshwater and coastal marine ecosystems - A global problem. Environmental Science and Pollution Research 10: 126-139.

Sorensen, D. L. and others 1988. First Phase Report. Great Salt Lake Interisland Diking: Water Quality Considerations. Utah State University Water Research Laboratory, p. 261. Water Research Laboratory, Utah State University.

Stephens, D. W. 1990. Changes in lake levels, salinity and the biological community of Great Salt Lake (Utah, USA), 1847-1987. Hydrobiologia 197: 139-146.

Stephens, D. W., and D. M. Gillespie. 1976. Phytoplankton production in Great Salt Lake, Utah, and a laboratory study of algal response to enrichment. Limnology and Oceanography 21: 74-87.

Strack, D. 2009. Utah's oil industry and Utah's railroads, p. Describes refinery construction and operations in Utah, especially SLC. UtahRails.Net.

Sturm, P. A. 1980. The Great Salt Lake brine system, p. 147-162. In J. W. Gwynn [ed.], Great Salt Lake. Utah Geological and Mineral Survey.

Tank, J. L., and W. K. Dodds. 2003. Nutrient limitation of epilithic and epixylic biofilms in ten North American streams. Freshwater Biology 48: 1031-1049.

The Forrester Group. 2001. Historical assessment of the Northewest Oil Drain, Salt Lake City, Utah, p. 77. The Forrester Group Environmental Managment and Planning.

Tiffany, M. A., M. R. Gonzalez, B. K. Swan, K. M. Reifel, J. M. Watts, and S. H. Hurlbert. 2007a. Phytoplankton dynamics in the Salton Sea, California, 1997-1999. Lake Reserv. Manage. 23: 582-605.

Tiffany, M. A., S. L. Ustin, and S. H. Hurlbert. 2007b. Sulfide irruptions and gypsum blooms in the Salton Sea as detected by satellite imagery, 1979-2006. Lake Reserv. Manage. 23: 637-652.

U.S. Department of Interior. 1998. Guidelines for interpretation of the biological effects of selected constituents in biota, water and sediment: Selenium, p. 139-184. In N. I. W. Q. Program [ed.].

UDEQ. 2011. Utah Department of Environmental Quality. Ecosystem assessment of mercury in the Great Salt Lake, Utah 2008. Salt Lake City, Utah.

http://utmtngroup.utah.gov/locations/G/greatsaltlake/strategy/docs/2014/05May/FinalReport0124 2011.pdf.

UDWQ. 2008. Final Report: Development of a Selenium Standard for the Open Waters of the Great Salt Lake. In U. D. o. E. Quality [ed.]. Utah Department of Environmental Quality.

Utah Geological Survey. 2011a. Chapter 9: Industrial minerals and metals, p. Metals production data. Utah Department of Natural Resources.

Utah Geological Survey. 2011b. Utah Energy and Mineral Statistics. Utah Department of Natural Resources.

Van Der Meide, J., and P. S. Nicholes. 1972. A study of the distribution of coliform bacteria in the Farmington Bay estuary of the Great Salt Lake, p. 121-133. In J. P. Riley [ed.], The Great Salt Lake and Utah's water resources. Proceedings of the first annual conference of the Utah Section 
of the American Water Resources Association. Utah Water Research Laboratory, Utah State University.

Varley, T., C. C. Stevenson, and W. S. Reid. 1921. Utah's Mineral Wealth. The Club - Chamber of Commerce.

Vest, J. L., M. R. Conover, C. Perschon, J. Luft, and J. O. Hall. 2009. Trace element concentrations in wintering waterfowl from the Great Salt Lake, Utah. Archives of Environmental Contamination and Toxicology 56: 302-316.

Waddell, B., C. Cline, N. Darnall, E. Boeke, and R. Sohn. 2009. Assessment of contaminants in the wetlands and open waters of the Great Salt Lake, Utah 1996-2000, p. 236.

Wurtsbaugh, W., D. Naftz, and S. Bradt. 2008. Spatial analyses of trophic linkages between basins in the Great Salt Lake. Utah Division of Forestry, Fire and State Lands. 66 p.

Wurtsbaugh, W. A. 1988. Iron, molybdenum and phosphorus limitation of $\mathrm{N}_{2}$ fixation maintains nitrogen deficiency of plankton in the Great Salt Lake drainage (Utah, USA). Verh. Int. Ver. Limnol. 23: 121-130.

Wurtsbaugh, W. A. 2009. Biostromes, brine flies, birds and the bioaccumulation of selenium in Great Salt Lake, Utah, p. 1-15. In A. Oren, D. Naftz, P. Palacios and W. A. Wurtsbaugh [eds.], Saline Lakes Around the World: Unique Systems with Unique Values. S.J. and Jessie Quinney Natural Resources Research Library.

Wurtsbaugh, W. A., J. Gardberg, and C. Izdepski. 2011. Biostrome communities and mercury and selenium bioaccumulation in the Great Salt Lake (Utah, USA). Science of the Total Environment 409: 4425-4434.

Wurtsbaugh, W. A., and A. M. Marcarelli. 2006. Eutrophication in Farmington Bay, Great Salt Lake, Utah. Report to the Central Davis Sewer Improvement District, Kaysville, UT, p. 91. Utah State University.

Wurtsbaugh, W. A., A. M. Marcarelli, and G. L. Boyer. 2012. Eutrophication and metal concentrations in three bays of the Great Salt Lake (USA). Final report to the Utah Division of Water Quality, Salt Lake City, Utah. 70 p.

http://digitalcommons.usu.edu/cgi/viewcontent.cgi?article=1548\&context=wats_facpub. 


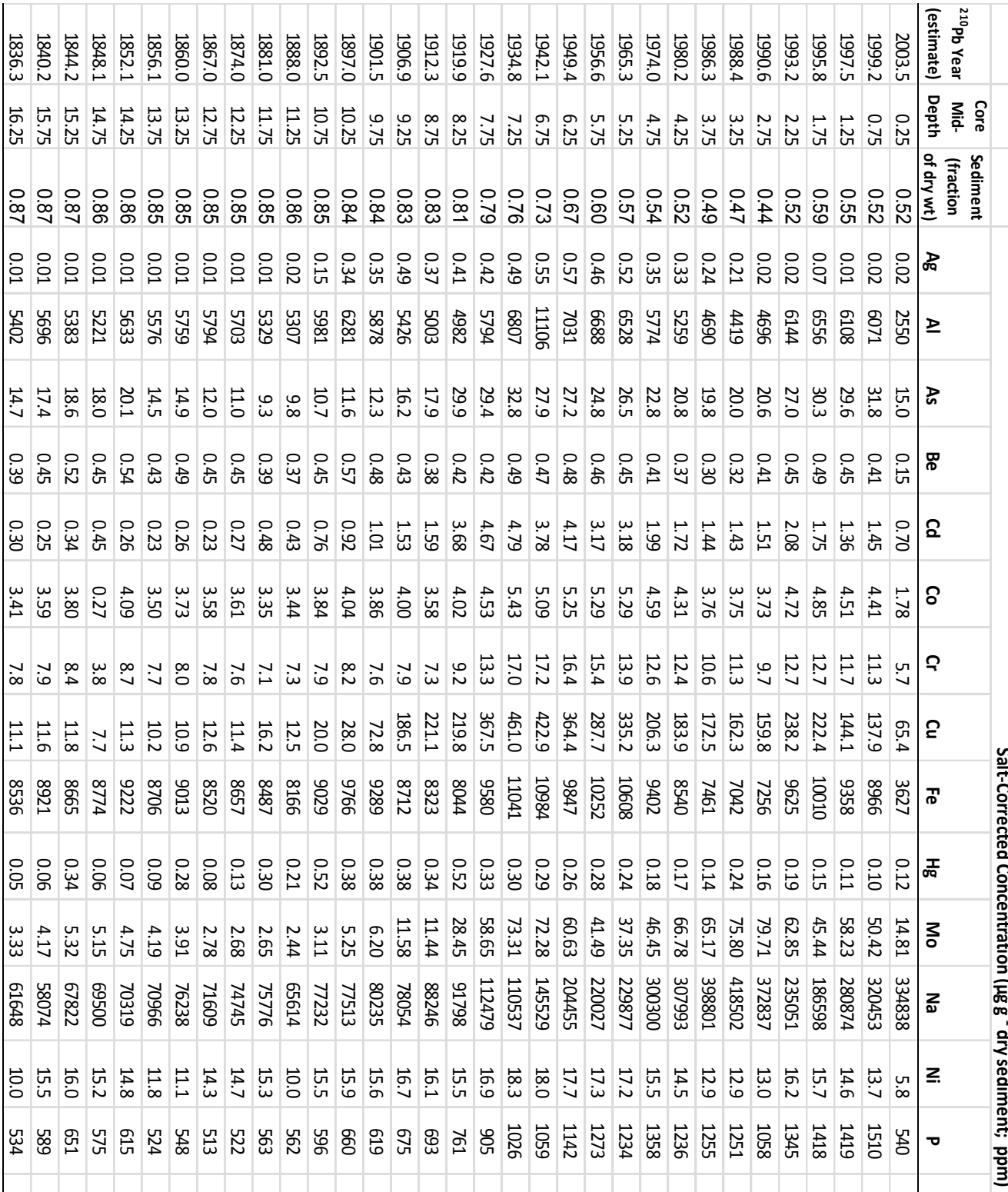

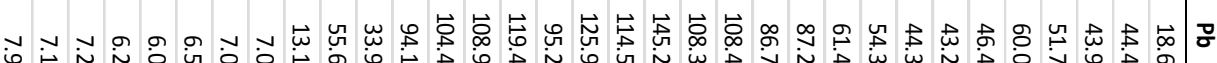

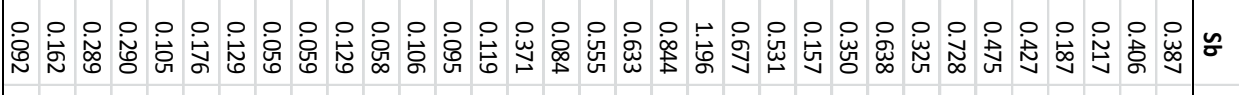

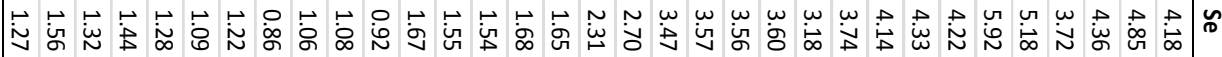

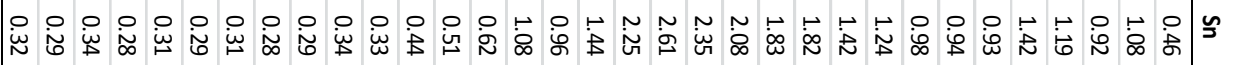

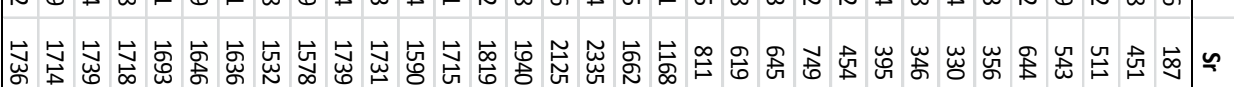

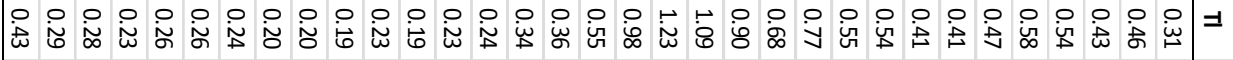

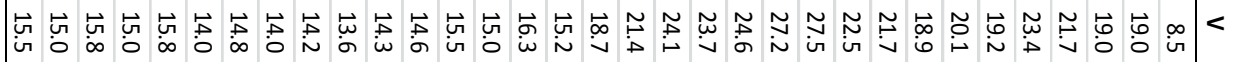

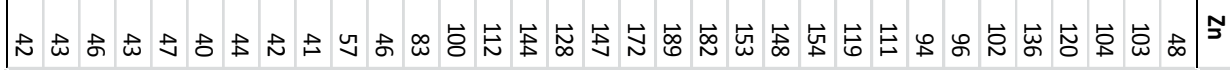




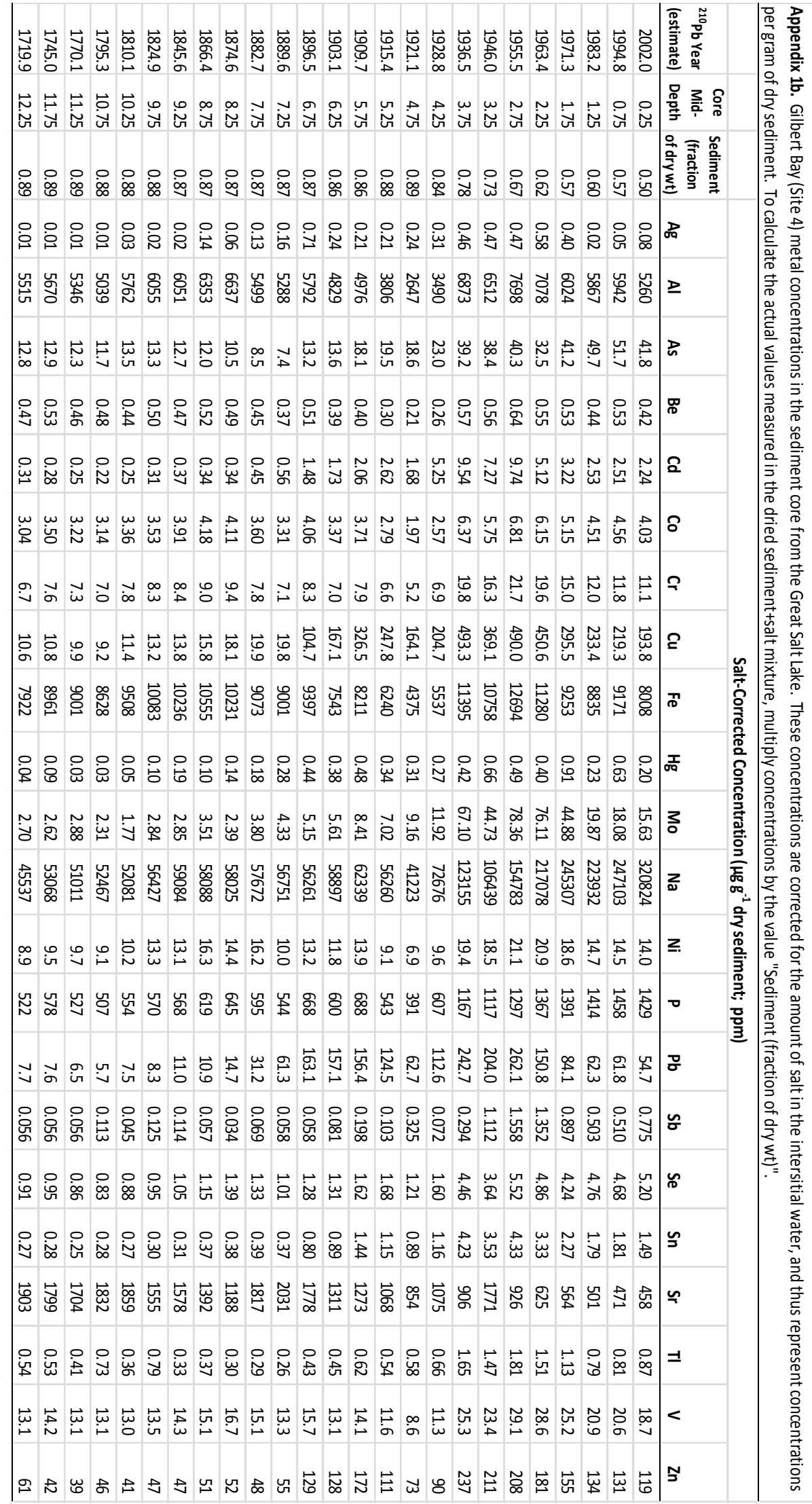




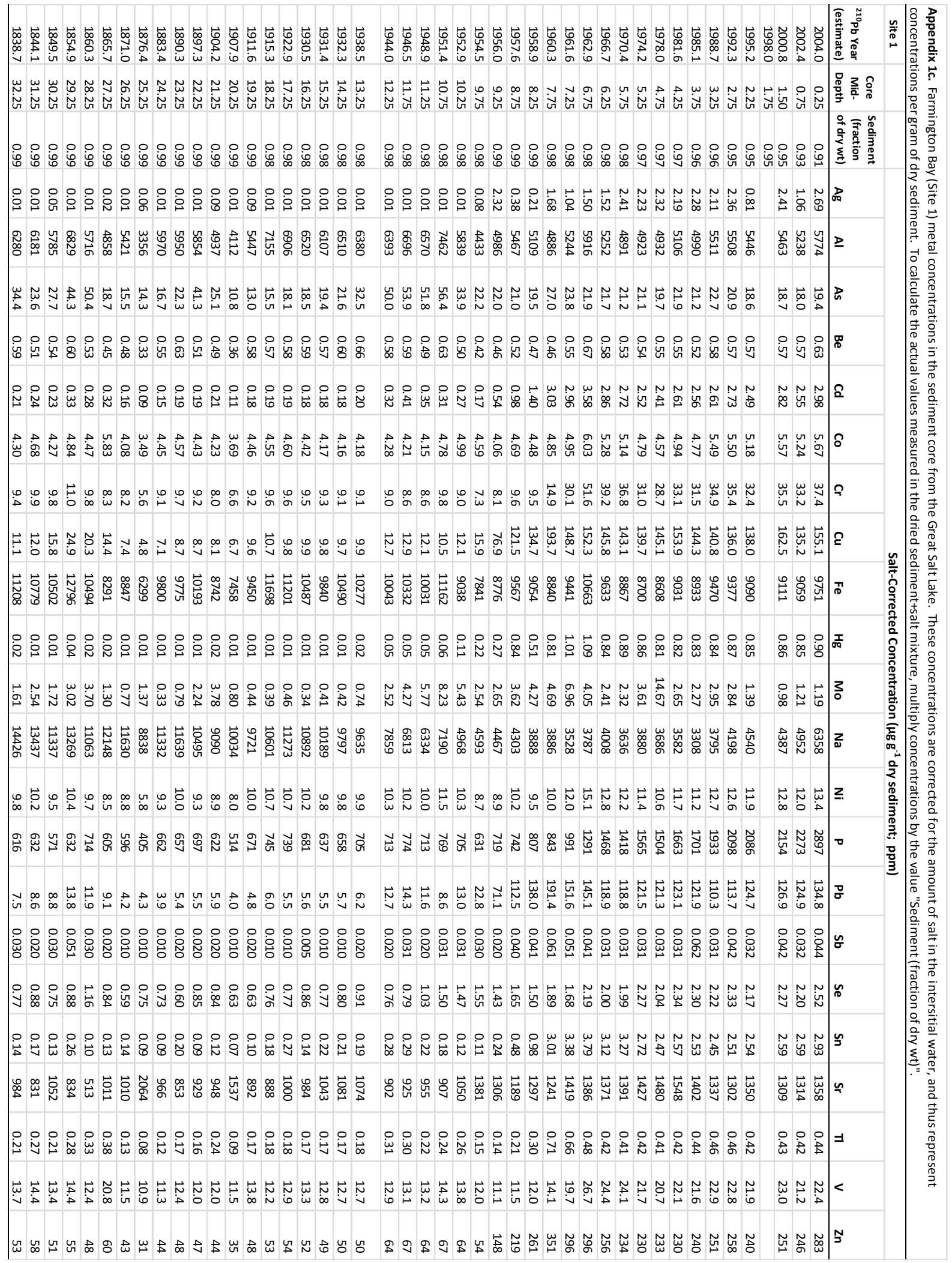


Appendix 2. Comparison of the chronologies of metal contaminants (copper, mercury, lead), with an indicator of fluvial transport of eroded material (aluminum) at Gilbert Bay Site 3 (A), Gilbert Bay Site 4 (B), and Farmington Bay Site 1 (C). The plotted values are the 3-point running means of the ratio of a metal at a given depth relative to the mean pre-industrial concentration (pre-1860).
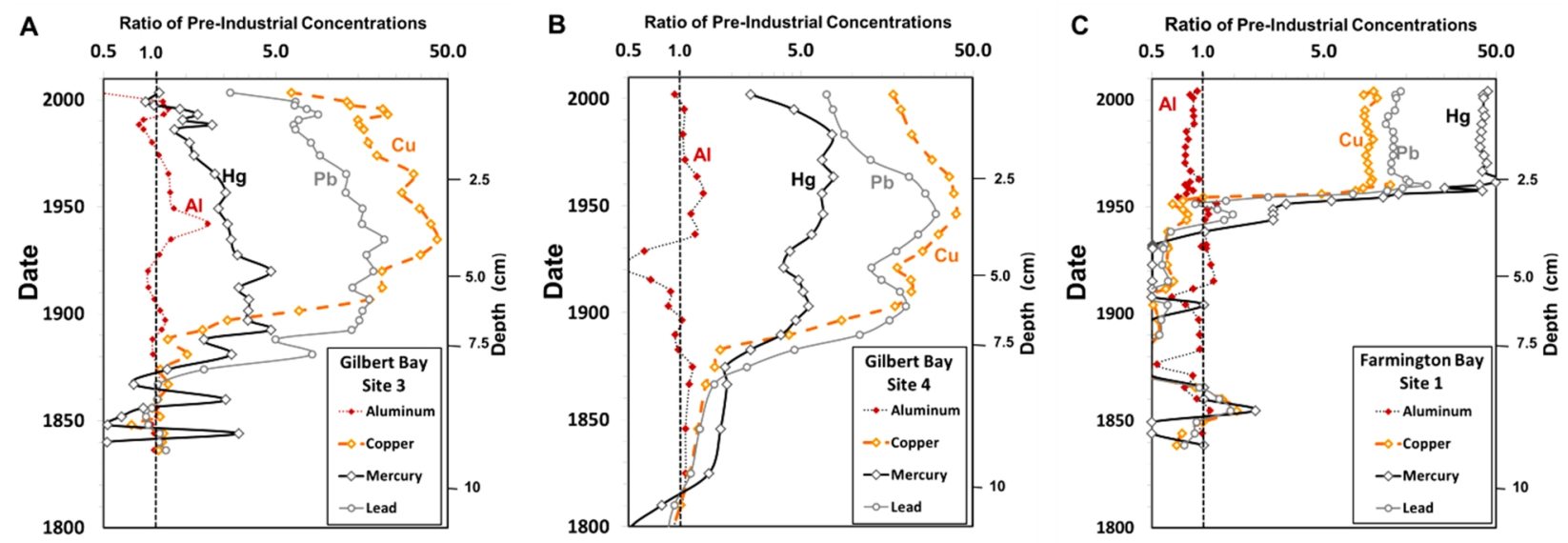